\title{
CATALYTIC FABRIC FILTRATION FOR SIMULTANEOUS NO, AND PARTICULATE CONTROL
}

\author{
DOE/PC/90361--T8 \\ Quarterly Technical Progress Report \\ for the Period July 1 - September 30, 1992 \\ DE93 007466
}

\author{
by \\ Greg F. Weber, Research Supervisor \\ Sumitra R. Ness, Research Engineer \\ Dennis L. Laudal, Research Engineer \\ Grant Dunham, Research Specialist \\ Energy and Environmental Research Center \\ University of North Dakota \\ Box 8213, University Station \\ Grand Forks, ND 58202-8213
}

Contracting Officer's Representative: Ms. Felixa Eskey

for

U.S. Department of Energy

Pittsburgh Energy Technology Center

626 Cochran Mill Road

Pittsburgh, PA 15236-0940

November 1992

Work Performed under Contract No. DE-AC22-90PC90361 


\section{DISCLAIMER}

This report was prepared as an account of work sponsored by an agency of the United States Government. Neither the United States Government nor any agency thereof, nor any of their employees makes any warranty, express or implied, or assumes any legal liability or responsibility for the accuracy, completeness or usefulness of any information, apparatus, product, or process disclosed, or represents that its use would not infringe privately owned rights. Reference herein to any specific commercial product, process, or service by trade name, trademark, manufacturer, or otherwise, does not necessarily constitute or imply its endorsement, recommendation, or favoring by the United States Government or any agency thereof. The views and opinions of authors expressed herein do not necessarily state or reflect those of the United States Government or any agency thereof. 


\section{TABLE OF CONTENTS}

$\underline{\text { Page }}$

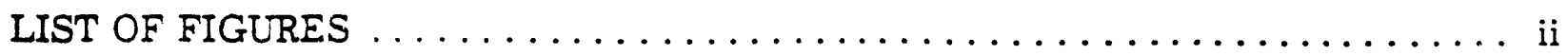

LIST OF TABLES $\ldots \ldots \ldots \ldots \ldots \ldots \ldots \ldots \ldots \ldots \ldots \ldots \ldots \ldots \ldots \ldots \ldots \ldots \ldots \ldots \ldots$

1.0 INTRODUCTION $\ldots \ldots \ldots \ldots \ldots \ldots \ldots \ldots \ldots \ldots \ldots \ldots \ldots \ldots \ldots \ldots \ldots \ldots$

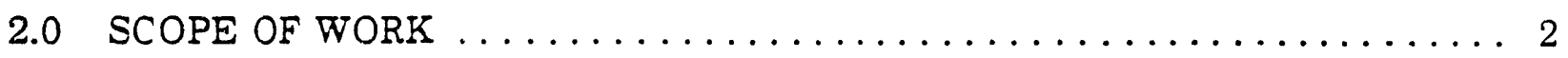

3.0 GOALS AND OBJECTIVES $\ldots \ldots \ldots \ldots \ldots \ldots \ldots \ldots \ldots \ldots \ldots \ldots \ldots \ldots$

4.0 ACCOMPLISHMENTS $\ldots \ldots \ldots \ldots \ldots \ldots \ldots \ldots \ldots \ldots \ldots \ldots \ldots \ldots \ldots \ldots \ldots$

4.1 Subtask 3.1 - Fundamental Testing ................... 4

4.2 Subtask 3.2 - Process Testing/Reverse-Gas System . . . . . . . . . . . 4

4.3 Subtask 3.3 - Process Testing/Pulse-Jet System .............. 5

4.3.1 Nitric Oxide Removal Efficiency ...................6 6

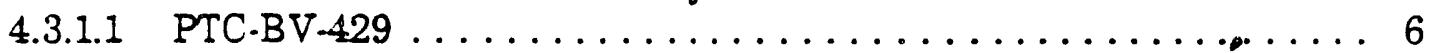

4.3 .1 .2 PTC-BT-430 $\ldots \ldots \ldots \ldots \ldots \ldots \ldots \ldots \ldots \ldots \ldots \ldots \ldots \ldots \ldots \ldots \ldots$

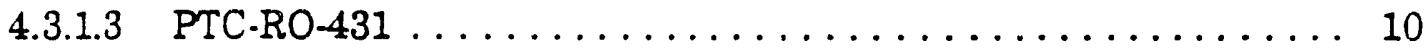

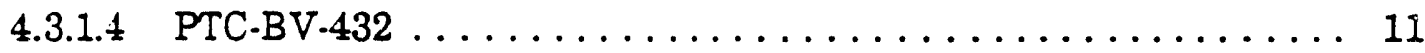

4.3.2 Particulate Collection ...................... 21

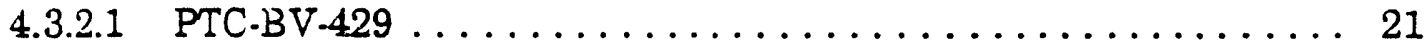

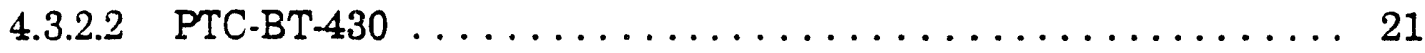

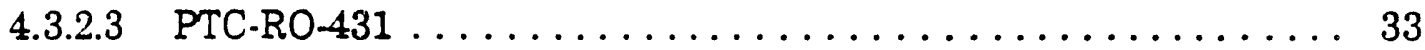

4.3.2.4 PTC-BV $-432 \ldots \ldots \ldots \ldots \ldots \ldots \ldots \ldots \ldots \ldots \ldots \ldots \ldots \ldots$

4.3.3 Summary of Pulse-Jet Baghouse Test Results ............ 39

4.t Subtask 3.4 - Fabric Durability Testing/Pulse-Jet System . . . . . . . . . 44

5.0 KEY PERSONNEL STAFFING REPORT $\ldots \ldots \ldots \ldots \ldots \ldots \ldots \ldots \ldots$

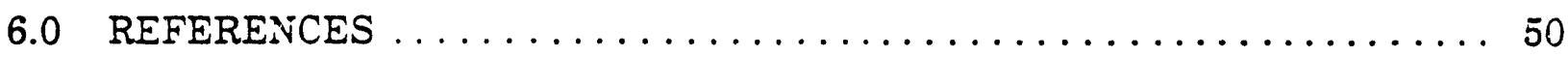




\section{LIST OF FIGURES}

Figure

$\underline{\text { Page }}$

1 Schematic of bench-scale reactor system $\ldots \ldots \ldots \ldots \ldots \ldots \ldots$

$2 \mathrm{NO}_{\mathrm{x}}$ removal efficiency as a function of air-to-cloth ratio and ammonia/NO,

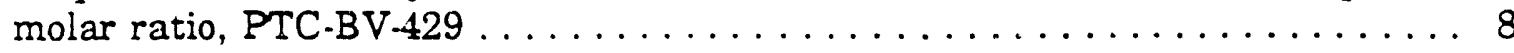

$3 \mathrm{NO}_{\mathbf{x}}$ removal efficiency as a function of air-to-cloth ratio and ammonia/NO, molar ratio, PTC-BT-430 ...................... 10

$4 \mathrm{NO}_{\mathrm{x}}$ removal eificiency as a function of air-to-cloth ratio and ammonia/ $\mathrm{NO}_{\mathrm{z}}$

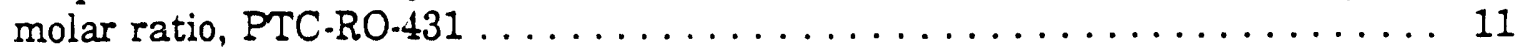

$5 \mathrm{NO}_{\mathrm{x}}$ removal efficiency as a function of air-to-cloth ratio and ammonia/NO molar ratio, PTC-BV.432, first set of gas-fired tests $\ldots \ldots \ldots \ldots \ldots \ldots$

$6 \mathrm{NO}_{\mathrm{x}}$ removal efficiency as a function of air-to-cloth ratio and ammonia/NO molar ratio, PTC-BV-432, initial bags, coal-fired tests . . . . . . . . . 13

$7 \mathrm{NO}_{\mathrm{x}}$ removal efficiency as a function of air-to-cloth ratio and ammonia/NO molar ratio, PTC-BV-432, second set of gas-fired tests . . . . . . . . . 14

$8 \mathrm{NO}_{\mathrm{z}}$ removal efficiency as a function of air-to-cloth ratio and ammonia/ $\mathrm{NO}_{\mathrm{x}}$ molar ratio, PTC-BV.432, second set of bags, coal-fired tests . . . . . . . 15

$9 \mathrm{NO}_{\mathrm{z}}$ removal efficiency as a function of air-to-cloth ratio and ammonia/ $\mathrm{NO}_{\mathbf{z}}$ molar ratio, PTC-BV-432, third set of gas-fired tests $\ldots \ldots \ldots \ldots \ldots \ldots$

$10 \mathrm{NO}_{\mathrm{x}}$ removal efficiency as a function of air-to-cloth ratio and ammonia/NO molar ratio, PTC-BV-432, fourth set of gas-fired tests $\ldots \ldots \ldots \ldots \ldots \ldots$

$11 \mathrm{NO}_{\mathrm{x}}$ removal efficiency as a function of air-to-cloth ratio and ammonia/NO molar ratio, PTC-BV-432, additional gas-fired tests $\ldots \ldots \ldots \ldots \ldots \ldots$

$12 \mathrm{NO}_{\mathrm{x}}$ removal efficiency as a function of air-to-cloth ratio and ammonia/NO molar ratio, PTC-BV-432, additional coal-fired tests $\ldots \ldots \ldots \ldots \ldots \ldots$

$13 \mathrm{NO}_{\mathrm{x}}$ removal efficiency as a function of time, PTC-RO-431 and PTC-BV-432 . . 18

$14 \mathrm{NO}_{\mathrm{z}}$ removal efficiency as a function of surface area, bench-scaie data versus

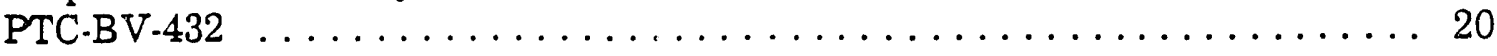

$15 \mathrm{SO}_{2}$ and $\mathrm{SO}_{3}$ concentrations as a function of time, PTC-BV-432 . . . . . 20

16 Baghouse differential pressure as a function of time, PTC-BV-429 . . . . . 31

17 Baghouse differential pressure as a function of time, PTC-BT-430 . . . . . 32 


\section{LIST OF FIGURES (continued)}

Figure

Page

18 Respirable mass emissions as a function of time, PTC-BV-432 $\ldots \ldots \ldots 35$

19 Particulate emissions as a function of time, PTC-BV-432 $\ldots \ldots \ldots \ldots \ldots$

20 Particulate collection efficiency as a function of time, PTC-BV-432 . . . . 37

21 Baghouse differential pressure as a function of time, PTC-BV-432 $\ldots \ldots \ldots 38$

22 Coulter counter data for baghouse hopper ash when firing Blacksville bituminous coal ........................... 41

23 Coulter counter data for baghouse hopper ash when firing Black Thunder subbituminous coal $\ldots \ldots \ldots \ldots \ldots \ldots \ldots \ldots \ldots \ldots \ldots \ldots \ldots$

24 Coulter counter data for baghouse hopper ash when firing fuel oil . . . . . . 42

25 Multicyclone data for Blacksville bituminous coal fly ash . . . . . . . . . 42

26 Multicyclone data for Black Thunder subbituminous coal fly ash . . . . . . 43

27 Steam Plant baghouse temperature and pressure drop as a function of time . . 47

28 Steam Plant baghouse air-to-cloth ratio as a function of time $\ldots \ldots \ldots \ldots . \ldots 4$

29 Multicyclone data from the Steam Plant baghouse . . . . . . . . . . . 49

30 Respirable mass emissions as a function of time for the Steam Plant baghouse .......................... 49 


\section{LIST OF TABLES}

Table

Page

1 Pulse-Jet Test Matrix $\ldots \ldots \ldots \ldots \ldots \ldots \ldots \ldots \ldots \ldots \ldots \ldots \ldots \ldots \ldots \ldots \ldots \ldots$

2 Results of Coal and Coal Ash Analysis for PTC-BV-429 through PTC-BV-432 . . 7

3 Particulate-Sampling Data for Pilot-Scale Catalytic Fabric Filter Tests . . . . 22

4 Multicyclone Data from PTC-BV-429 $\ldots \ldots \ldots \ldots \ldots \ldots \ldots \ldots \ldots \ldots \ldots$

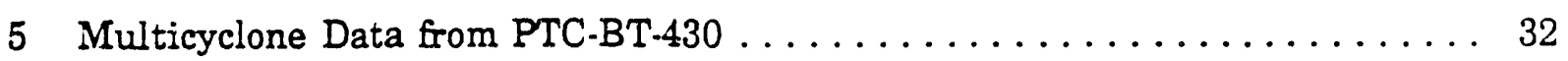

6 Multicyclone Data from PTC-BV-432 $\ldots \ldots \ldots \ldots \ldots \ldots \ldots \ldots \ldots \ldots$

7 Baghouse Hopper Ash Analysis Results $\ldots \ldots \ldots \ldots \ldots \ldots \ldots \ldots \ldots . \ldots \ldots$

8 Vanadium Concentration on Catalytic Fabric Filter Bags ..............

9 Vanadium Concentration Analysis Results for Coal and Ash Samples ..... 45

$10 \mathrm{XRF}$ Ash Analysis of Steam Plant Baghouse Hopper Ash ............ 50

11 Planned Versus Actual Workhours for Key Personnel Through

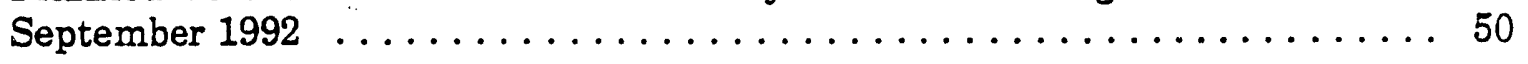




\section{CATALYTIC FABRIC FILTRATION FOR SIMULTANEOUS NO AND PARTICULATE CONTROL}

\subsection{INTRODUCTION}

The University of North Dakota Energy and Environmental Research Center (EERC); Owens-Corning Fiberglas Corporation (OCF); and Stearns-Roger, a division of United Engineers \& Constructors (UE\&C) are conducting research to develop a catalytic fabric filter for simultaneous $\mathrm{NO}_{\mathbf{x}}$ and particulate control. Funding for the project is being provided by the U.S. Department of Energy/Pittsburgh Energy Technology Center (DOE/PETC), Consolidated Edison Company of New York Inc. (Con Edison), and the Empire State Electric Energy Research Corporation (ESEERCO).

The DOE/PETC funding was secured as a result of a competitive award from the DOE/PETC Advanced NO, Control program. The objective of this program is to develop advanced concepts for the removal of $\mathrm{NO}_{\mathbf{x}}$ from flue gas emitted by coal-fired utility boilers, or for the control of $\mathrm{NO}_{\mathbf{x}}$ formation by advanced combustion modification techniques. Funded projects are required to focus on the development of technology that significantly advances the state of the art using a process or a combination of processes capable of reducing $\mathrm{NO}_{\mathrm{s}}$ emissions to $60 \mathrm{ppm}$ or less. The concept must have successfully undergone sufficient laboratory-scale development to justify scaleup for further evaluation at the pilot scale (not to exceed $5 \mathrm{MWe}$ in size). Other requirements include production of a nonhazardous waste or a salable by-product. The concept should have application to both new and retrofit coal-fired systems. The concept should also show the potential for a $50 \%$ cost savings when compared to a commercial selective catalytic reduction (SCR) process capable of meeting the 60-ppm $\mathrm{NO}_{\mathbf{x}}$ emission limit.

The EERC approach to meeting the program objective involves the development of a catalytic fabric filter for simultaneous $\mathrm{NO}_{\mathbf{x}}$ and particulate control. The idea of applying either permanent or throwaway catalysts to a high-temperature fabric filter for $\mathrm{NO}_{\mathbf{z}}$ control is not new (1-4). However, advances at OCF have shown that a high-activity catalyst can be applied to a high-temperature woven glass cloth resulting in a fabric filter material that can operate at temperatures higher than the maximum operating temperatures of commercially available, coated glass fabric. The $\mathrm{NO}_{\mathbf{x}}$ is removed by catalytic reduction with ammonia to form nitrogen and water. The catalyst employed at this time is vanadium/titanium, but the exact catalyst composition and the unique method of applying the catalyst to high-temperature glass fabric are the property of OCF (5). Other catalyst options are being evaluated by OCF in order to improve catalyst performance and minimize catalyst cost.

Bench-scale experimental results to date have shown that over $90 \% \mathrm{NO}_{\mathrm{s}}$ removal can be achieved, the catalyst/fabric has promising self-abrasion characteristics, and the potential exists for substantially reduced cost when compared with conventional $\mathrm{SCR}$ fabric filtration technology $(6,7)$. However, development of the technology requires further evaluation of air-to-cloth ratio, ammonia slip, $\mathrm{SO}_{2}$ oxidation to $\mathrm{SO}_{3}$, temperature cycling, catalyst-coated fabric preparation, fuel impacts, fabric cleaning (reverse-gas versus pulse-jet), catalyst life (poisoning and resistance to erosion), and filter performance/life (particulate control, differential pressure, and durability). 


\subsection{SCOPE OF WORK}

following:

The specific approach being used to address these issues is represented by the

Task 1.-Program Definition

Task 2--Design and Construct Test Unit

Task 3--Experimental Program and Data Reduction

Task 4--Conceptual Design and Economic Evaluation

Task 5.-Test Unit Removal

Task 1, Program Definition, required preparation of a Project Management Plan. This document contains a detailed scope of work, project schedule, and project budget; identifies key project personnel; and presents an appropriate QA/QC plan for the project. Task 2, Design and Construct Test Unit, is divided into three subtasks. Subtasks 2.1 and 2.2 involved the detailed design of the test facility on which the experimental program is being performed, the construction of the test facility, and an operational shakedown of the system prior to initiating the experimental effort. Subtask 2.3 involves preparation of the catalyst-coated fabric filters that are being evaluated in the experimental effort.

Task 3, Experimental Program and Data Reduction, has four subtasks. Subtask 3.1, Fundamental Testing, is intended as a support effort to the primary experimental test plan. This effort should supply information needed to understand the process mechanism thoroughly, allow screening of additional fabric samples, address the issue of catalyst pcisoning, and generally support the pilot-scale effort. Subtask 3.2, Process Testing/Reverse-Gas System, is intended to evaluate process performance in a pilot-scale reverse-gas fabric filter, identify and optimize important process variables, and provide data for a conceptual design. Subtask 3.3, Process Testing/Pulse-Jet System, will evaluate process performance in a pilot-scale pulse-jet fabric filter. Subtask 3.4, Fabric Durability Testing/Pulse-Jet System, will evaluate catalyst-coated fabric durability/performance for up to 12,000 hours in a slipstream pulse-jet baghouse.

Based on the results of Task 3, a technical and economic assessment of the catalytic fabric filter concept will be completed in Task 4, Conceptual Design and Economic Evaluation. Task 5, Test Unit Removal, requires the identification of all major test facilities, equipment, and instruments and hardware, and their condition, ownership, and proposed disposition.

The EERC is the primary contractor for the project and is responsible for the management'direction of all technical and administrative project activities. The EERC has specifically performed all work associated with Task 1 and Subtasks 2.1 and 2.2 and will perform Tasks 3 and 5 .

OCF will perform and/or supervise all work associated with Subtask 2.3, including manufacturing the "S" glass fabric, coating the fabric, and manufacturing the filter bags for the reverse-gas and pulse-jet systems. This effort, as well as technical support, is being provided by OCF as a cost share to the project.

UE\&C, as a subcontractor to the EERC, provided technical support for Task 1 and will perform Task 4. EERC personnel involved in the Task 3 effort and OCF personnel will provide input to UE\&C Task 4 activities. 
The project schedule is based on a project start date of October 1, 1990, and assumes a project duration of 36 months. Therefore, the planned project completion date is September 30, 1993.

Federal funding accounts for roughly $56 \%$ of the total project budget. Commercial funding for the project makes up the remaining 44\%. Con Edison and ESEERCO are each funding $12 \%$ of the project cost, and OCF is contributing $10 \%$ in the form of catalystcoated filter bags and technical support for the project. The remaining $10 \%$ is uncommitted at this time, but the EERC and OCF are pursuing funding options in an effort to obtain a formal commitment for the remaining commercial cost share as soon as possible.

\subsection{GOALS AND OBJECTIVES}

The overall objective of this project is the development of a catalyst-coated fabric filter for simultaneous $\mathrm{NO}_{\mathrm{x}}$ and particulate control. The catalyst-coated fabric filter must provide high removal efficiency of $\mathrm{NO}_{x}$ and particulate matter. An acceptable bag and catalyst life must be demonstrated, and process economics must show a significant cost savings when compared to a commercial SCR process and conventional particulate control. Specific goals include the following:

- Reduce $\mathrm{NO}_{\mathrm{x}}$ emissions to 60 ppm or less

- Demonstrate particulate removal efficiency of $>99.5 \%$

- Demonstrate a bag/catalyst life of $>1$ year

- Control ammonia slip to $<25 \mathrm{ppm}$

- Show that catalytic fabric filtration can achieve a $50 \%$ cost savings over conventional fabric filtration and SCR control technology

- Determine compatibility with $\mathrm{SO}_{2}$ removal systems

- Show that the concept results in a nonhazardous waste product

Specific project activities during the past quarter (July through September 1992) were to include the following:

- Continue Subtask 3.1 - Fundamental Testing

- Continue Subtask 3.2 - Process Testing/Reverse-Gas System

- Continue Subtask 3.3 - Process Testing/Pulse-Jet System

- Continue Subtask 3.4 - Fabric Durability Testing/Pulse-Jet System 


\subsection{ACCOMPLISHMENTS}

\subsection{Subtask 3.1 - Fundamental Testing}

Originally the bench-scale reactor system had been set up and operated in a lab belonging to the School of Engineering and Mines on the University of North Dakota (UND) campus in order to facilitate performance of experimental activities by graduate students working on the project. However, graduate students were unable to fully meet the needs of the project; therefore, it was decided that EERC staff members would complete the remainder of the activities. To facilitate the efficient use of personnel time, it was decided that the bench-scale equipment would be relocated in a laboratory trailer on the EERC site.

Modifications to the beilch-scale system were more significant than originally anticipated. The problems with calibration of the mass-flow controllers for nitric oxide (NO) and ammonia $\left(\mathrm{NH}_{3}\right)$ were due to the low flow rates required and other problems associated with compressible flow. In order to eliminate these problems, it was necessary to increase the flow rates. Unfortunately, the original quartz reactor system was not able to accommodate the increased flow rates and still remain within the operational specifications of the project; therefore, EERC personnel assembled a stainless steel reactor system, which was previously used for the study of nitric oxide (NO) oxidation to nitrogen dioxide $\left(\mathrm{NO}_{2}\right)$.

The bench-scale reactor system (Figure 1) consists of four reactors housed in a heated insulated box. Eawh. :eactor is connected to a manifold which permits the evaluation of four fabric samples without having to cool and dismantle the reactor system for each fabric sample. This configuration should decrease the time required to complete the remaining test activities. Calibrated mass-flow controllers, flowmeters, and pressure gages are used to control and monitor the flow of individual gas components. The installation of pressure gauges was necessary to ensure that the compressible flow problems associated with the earlier system do not recur. Assembly of the reactor system was completed in September along with several shakedown tests to verify system performance. Results from the shakedown tests identified some inconsistencies in either the performance of the $\mathrm{NO}_{\mathrm{x}}$ analyzer or several calibration gases. These inconsistencies have not been resolved; therefore, the catalyst deactivation experiments have not begun. Bench-scale catalyst deactivation experiments should be completed in the next quarter, assuming the experimental system is demonstrated to function properly, providing reasonable nitric oxide and ammonia balances.

While the equipment problems have prevented the completion of planned experimental activities, EERC personnel have completed a literature review, initiated this past spring, concerning catalyst deactivation/poisoning. The results of this literature review will be included in the Topical Report for Subtask 3.1.

\subsection{Subtask 3.2 - Process Testing/Reverse-Gas System}

Subtask 3.2 activities during the quarter primarily involved meeting routine monthly and quarterly reporting requirements. A short paper was prepared in July for presentation at the contractors' review meeting held on July 27.31, 1992, in Pittsburgh, Pennsylvania. The paper, entitled "Catalytic Fabric Filtration for Simultaneous NO and Particulate Control," briefly summarized the results from the 100-hour reverse-gas test periods. 


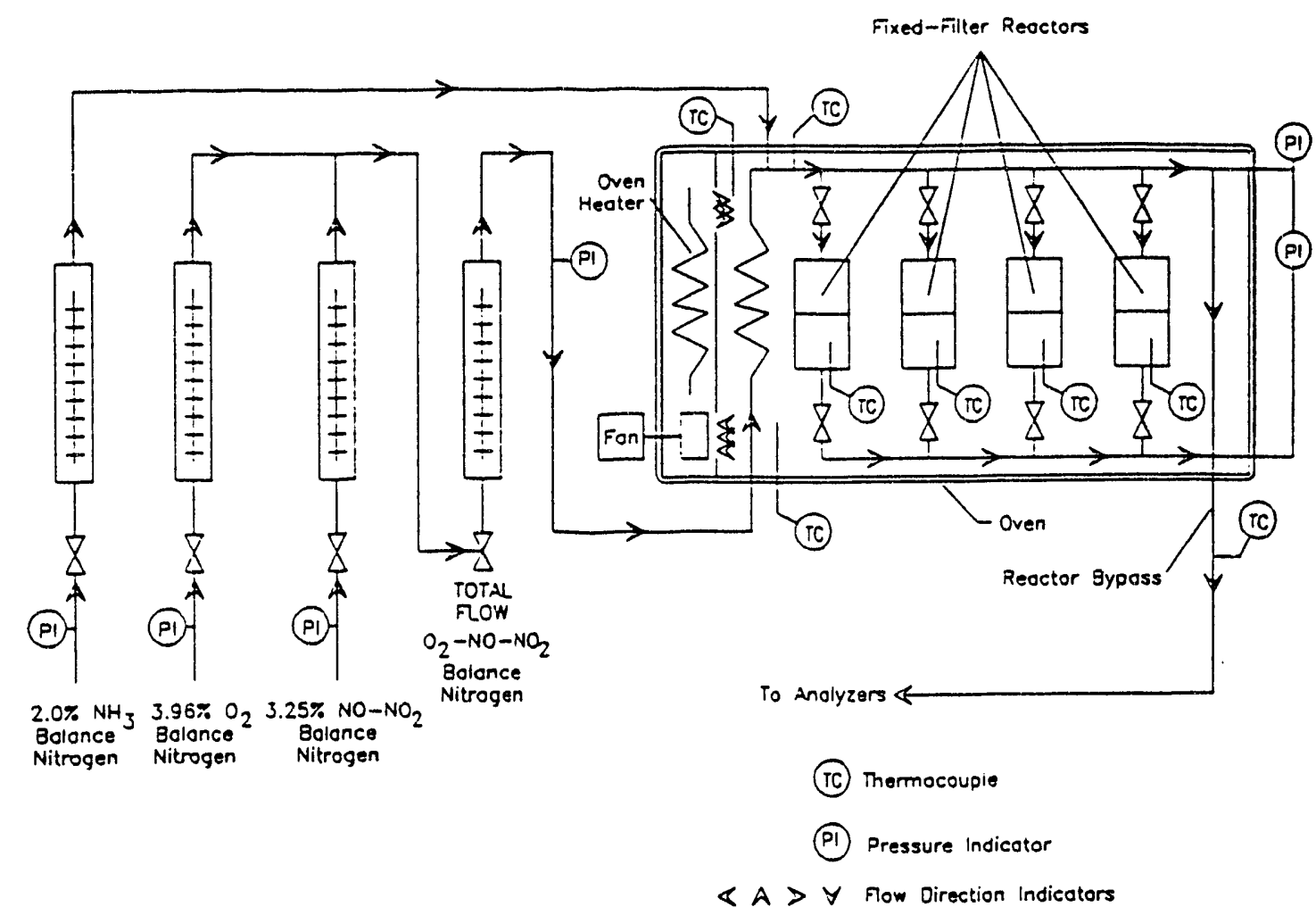

Figure 1. Schematic of bench-scale reactor system.

\subsection{Subtask 3.3 - Process Testing/Pulse-Jet System}

Subtask 3.3, Process Testing/Pulse-Jet System, activities this past quarter involved the completion of three 100-hour test periods (PTC-BV-429, PTC-BT-430, and PTC-RO431), and a 500-hour test, PTC-BV-432. The completed test matris is shown in Table 1. The purpose of the first three 100-hour test periods was to evaluate the effects of fuel type, air-to-cloth ratio, and ammonia $\mathrm{NO}_{\mathbf{z}}$ molar ratio on the ability of the catalyst-coated fabric to control particulate and nitric oxide $\left(\mathrm{NO}_{\mathrm{x}}\right.$ ) emissions. The purpose of the 500-hour test was to maintain a constant air-to-cloth ratio and determine the effect of ammonia/ $\mathrm{NO}_{\mathrm{x}}$ molar ratio $(0.6,0.7,0.8$, and 0.9$)$ on $\mathrm{NO}_{\mathrm{x}}$ removal efficiency and ammonia slip over sufficiently long periods of time to ensure steady state operation.

To determine the effects of fuel type on catalyst-coated fabric performance, the baghouse temperature was held constant at $650^{\circ} \mathrm{F}$, and flue gas was generated by firing a pulverized Blacksville bituminous, a pulverized Black Thunder subbituminous, and a fuel oil in a pilot-scale combustor. The average ultimate, proximate, and sieve analyses for each of the 100-hour test coals, as well as the ultimate and proximate analysis for the fuel oil, is presented in Table 2. The data presented in Table 2 shows that the three fuels used during this series of tests represents a broad range of fuel characteristics in terms of moisture content ( $<2 \%$ to $24 \%$ ), ash content $(0.2 \%$ to $8.2 \%$ ) and characteristics (low and high alkali content), sulfur content $(0.37 \%$ to $2.37 \%)$, and heating value $(8,941$ to $18,066 \mathrm{Btu} / \mathrm{lb}$ ). Ash analysis was not available for the oil-fired test (PTC-RO-431) due to the dilution effect of dolomite used to precoat the catalyst-coated bags. 
TABLE 1

Pulse-Jet Test Matrix ${ }^{1}$

\begin{tabular}{|c|c|c|c|c|c|}
\hline \multirow{2}{*}{ 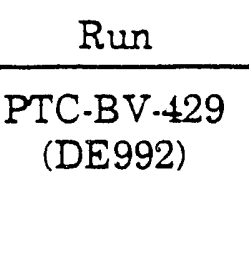 } & \multirow{2}{*}{$\begin{array}{c}\text { A/C Ratio } \\
2.0 \\
3.0 \\
4.0 \\
6.0\end{array}$} & \multicolumn{4}{|c|}{ Ammonia/NO $\mathrm{NO}_{\mathrm{x}}$ Molar Ratio } \\
\hline & & $\begin{array}{l}. . \\
.- \\
.-\end{array}$ & $\begin{array}{l}0.7 \\
0.7 \\
0.7 \\
0.7\end{array}$ & $\begin{array}{l}0.8 \\
0.8 \\
0.8 \\
0.8\end{array}$ & $\begin{array}{l}0.9 \\
0.9 \\
0.9 \\
0.9\end{array}$ \\
\hline $\begin{array}{l}\text { PTC-BT-430 } \\
\text { (DE992) }\end{array}$ & $\begin{array}{l}2.0 \\
3.0 \\
4.0 \\
6.0\end{array}$ & $\begin{array}{l}. . \\
. . \\
. . \\
.\end{array}$ & $\begin{array}{l}0.7 \\
0.7 \\
0.7 \\
0.7\end{array}$ & $\begin{array}{l}0.8 \\
0.8 \\
0.8 \\
0.8\end{array}$ & $\begin{array}{l}0.9 \\
0.9 \\
0.9 \\
0.9\end{array}$ \\
\hline $\begin{array}{l}\text { PTC-RO-431 } \\
\text { (DE992) }\end{array}$ & $\begin{array}{l}2.0 \\
3.0 \\
4.0 \\
6.0\end{array}$ & $\begin{array}{l}. . \\
. . \\
.-\end{array}$ & $\begin{array}{l}0.7 \\
0.7 \\
0.7 \\
0.7\end{array}$ & $\begin{array}{l}0.8 \\
0.8 \\
0.8 \\
0.8\end{array}$ & $\begin{array}{l}0.9 \\
0.9 \\
0.9 \\
0.9\end{array}$ \\
\hline $\begin{array}{l}\text { PTC-BV-432 } \\
\text { (DE992) }\end{array}$ & 3.5 & 0.6 & 0.7 & 0.8 & 0.9 \\
\hline
\end{tabular}

$\therefore$ Baghouse bulk gas temperature was nominaily $650^{\circ} \mathrm{F}$ for all test periods, except PTC-BV-429 and PTC-BT-430. For these two runs, the baghouse bulk gas temperature was nominally $550^{\circ} \mathrm{F}$ during the last test period in each run.

Owens-Corning Fiberglas Inc. provided catalyst-coated pulse-jet filter bags, woven from high-temperature glass fibers, for each test. All bags tested were 6 inches in diameter by roughly 8 -feet long. The catalyst-coated fabric filters were prepared using a high-temperature double-beam woven glass consisting of D-fibers (6.5 micron) and having a fabric weight of 22 ounces/yd $\mathrm{d}^{2}$ (DE992 fabric). Seven coats of an organic-based vanadium/titanium catalyst were applied to the 22 -ounce/yd $\mathrm{d}^{2}$ double-beam fabric. This is the same type of fabric used during 100-hour reverse-gas tests PTC-IL6-414 and PTC-IL6428. Heat treatment for all bags consisted of a 4 to 4.5 -hour heatup period during which the baghouse temperature was raised from roughly $350^{\circ}$ to $700^{\circ} \mathrm{F}$, followed by a heat treatment period of roughly 4 to 5.5 hours at $710^{\circ} \mathrm{F}$, and $2.7 \%$ to $4.5 \%$ oxygen. The flue gas for heat treatment was generated by firing natural gas.

\subsubsection{Nitric Oxide Removal Efficiencv}

\subsubsection{PTC-BV-429}

Flue gas for this 100-hour test was generated by firing a Blacksville bituminous coal in a pilot-scale pulverized coal-fired (pc-fired) combustor. Results from the 100-hour test were quite good. Nitric oxide reduction averaged $>90 \%$ at an air-to-cloth ratio of $4 \mathrm{ft} / \mathrm{min}$ (six bags on-line); an ammonia $\mathrm{NO}_{\mathrm{z}}$ molar ratio of 0.9 , roughly $772-\mathrm{ppm} \mathrm{NO}_{\mathrm{x}}$ in the flue gas; and an average bulk gas baghouse temperature of $657^{\circ} \mathrm{F}$. At an air-to-cloth ratio of 3 $\mathrm{ft} / \mathrm{min}$ (eight bags on-line), an ammonia/ $\mathrm{NO}_{\mathrm{z}}$ molar ratio of 0.71 , and an average bulk gas temperature of $657^{\circ} \mathrm{F}$, nitric oxide removal averaged $74 \%$. 
TABLE 2

Results of Coal and Coal Ash Analysis for PTC.BV-429 through PTC.BV-432.b

\begin{tabular}{|c|c|c|c|}
\hline & $\begin{array}{l}\text { Blacksville } \\
\text { Bituminous }\end{array}$ & $\begin{array}{l}\text { Black Thunder } \\
\text { Subbituminous }\end{array}$ & Residual Oil \\
\hline \multicolumn{4}{|c|}{ Proximate Analysis (wt\%) } \\
\hline $\begin{array}{l}\text { Moisture } \\
\text { Volatile Matter } \\
\text { Fixed Carbon } \\
\text { Asin }\end{array}$ & $\begin{array}{r}1.72 \\
35.68 \\
54.37 \\
8.21\end{array}$ & $\begin{array}{l}24.3 \\
35.68 \\
35.01 \\
5.00\end{array}$ & $\begin{array}{r}1.60 \\
94.35 \\
3.83 \\
0.20\end{array}$ \\
\hline \multicolumn{4}{|l|}{ Cltimate Analysis (wt\%) } \\
\hline $\begin{array}{l}\text { Hydrogen } \\
\text { Carbon } \\
\text { Nitrogen } \\
\text { Sulfur } \\
\text { Oxygen } \\
\text { Ash }\end{array}$ & $\begin{array}{r}4.97 \\
74.91 \\
1.36 \\
2.37 \\
8.17 \\
8.21\end{array}$ & $\begin{array}{r}6.74 \\
52.18 \\
0.70 \\
0.37 \\
35.01 \\
5.00\end{array}$ & $\begin{array}{r}10.26 \\
88.65 \\
0.25 \\
1.96 \\
- \\
0.20\end{array}$ \\
\hline Heating Value (Btw/lb) & 13,212 & 8,941 & 18,066 \\
\hline $\begin{array}{l}\text { Percent as Oxides (wt\%) } \\
\mathrm{SiO}_{2} \\
\mathrm{Al}_{2} \mathrm{O}_{3} \\
\mathrm{Fe}_{2} \mathrm{O}_{3} \\
\mathrm{TiO}_{2} \\
\mathrm{P}_{2} \mathrm{O}_{8} \\
\mathrm{CaO} \\
\mathrm{MgO} \\
\mathrm{Na}_{2} \mathrm{O} \\
\mathrm{K}_{2} \mathrm{O} \\
\mathrm{SO}_{3}\end{array}$ & $\begin{array}{r}43.98 \\
21.95 \\
25.27 \\
0.97 \\
0.30 \\
4.57 \\
2.86 \\
0.74 \\
0.84 \\
4.53\end{array}$ & $\begin{array}{r}33.65 \\
15.29 \\
5.69 \\
1.08 \\
1.19 \\
21.15 \\
7.69 \\
1.1 \\
0.29 \\
12.90\end{array}$ & $\begin{array}{l}\mathrm{NA}^{\circ} \\
\mathrm{NA} \\
\mathrm{NA} \\
\mathrm{NA} \\
\mathrm{NA} \\
\mathrm{NA} \\
\mathrm{NA} \\
\mathrm{NA} \\
\mathrm{NA} \\
\mathrm{NA}\end{array}$ \\
\hline \multicolumn{4}{|c|}{ Ash Fusion Temperature $\left({ }^{\circ} \mathrm{F}\right)$} \\
\hline $\begin{array}{l}\text { Initial } \\
\text { Softening } \\
\text { Hemisphere } \\
\text { Fluid }\end{array}$ & $\begin{array}{l}2,182 \\
2,274 \\
2,328 \\
2,384\end{array}$ & $\begin{array}{l}2,183 \\
2,213 \\
2,228 \\
2,244\end{array}$ & $\begin{array}{l}\text { NA } \\
\text { NA } \\
\text { NA } \\
\text { NA }\end{array}$ \\
\hline \multicolumn{4}{|l|}{ Sieve Analysis } \\
\hline Screen Mesh Size & Wt. \% Ketained & & \\
\hline $\begin{array}{l}100 \\
140 \\
200 \\
230 \\
270 \\
325 \\
\text { Pan }\end{array}$ & $\begin{array}{c}8.68 \\
8.588 \\
12.23 \\
6.88 \\
8.33 \\
\therefore .39 \\
53.01\end{array}$ & $\begin{array}{r}25.31 \\
13.81 \\
13.87 \\
4.99 \\
4.99 \\
1.21 \\
33.44\end{array}$ & $\begin{array}{l}\text { NA } \\
\text { NA } \\
\text { NA } \\
\text { NA } \\
\text { NA } \\
\text { NA } \\
\text { NA }\end{array}$ \\
\hline Total $\%$ & 99.10 & 97.60 & NA \\
\hline
\end{tabular}

- Fuel analysis is presented on a "as-fired" basis.

- Data represent an arerage of four coal analyses for the Blacksville bituminous and tro analyses for the Black Thunder subbituminous.

- Not arailable. 
Figure 2 plots the $\mathrm{NO}_{\mathrm{z}}$ removal efficiency and ammonia slip (as \% of inlet $\mathrm{NO}_{\mathrm{x}}$ ) as a function of ammonia $: \mathrm{O}_{2}$ molar ratio. As in the previous quarterly report (8), $\mathrm{NO}_{2}$ reduction data has been plotted as two separate data sets $\left(\mathrm{NO}_{\mathrm{x}}\right.$ reduction at air-to-cloth ratios 2 to $3 \mathrm{ft} / \mathrm{min}$ and 4 to $6 \mathrm{ft} / \mathrm{min}$ ). However, unlike previous tests where there was a distinct difference, it appears that air-to-cloth ratio had little effect on $\mathrm{NO}_{\mathrm{x}}$ reduction during this 100 -hour test period. At all air-to-cloth ratios and ammonia/NO molar ratios $<0.9, \mathrm{NO}_{2}$ reduction was greater than theoretical, based on Reactions 1,2 , and 3 .

If the observation is not due to data variability, one explanation may be that some of the nitric oxide (NO) or nitrogen dioxide $\left(\mathrm{NO}_{2}\right)$ is being reduced as a result of reactions 4 and 5.

However, this is not consistent with mechanisms typically reported in the literarire for an oxidizing environment. Also, as the ammonia/ $\mathrm{NO}_{\mathbf{z}}$ molar ratio decreases, the difference between actual and theoretical $\mathrm{NO}_{2}$ removal increases. Further data evaluation, a literature review, and possibly some bench-scale testing will be necessary before a firm conclusion can be drawn.

Results from ammonia slip measurements using wet chemistry techniques d" Iso presented in Figure 2. The data shows ammonia slip values ranging from $<1 \%$ u $\mathrm{NO}_{\mathrm{x}}$ at an air-to-cloth ratio of $3 \mathrm{ft}^{\prime}$ :inin to $6.6 \%$ of inlet $\mathrm{NO}_{\mathrm{x}}$ at an air-to-cloth ratio of 6 $\mathrm{ft} / \mathrm{min}$. At air-to-cloth ratios of 2 and $4 \mathrm{ft} / \mathrm{min}$, and a nominal ammonia $\mathrm{NO}_{\mathrm{x}}$ molar ratio of 0.9 , ammonia slip values range from $2 \%$ to $4 \%$ of inlet $\mathrm{NO}_{\mathbf{x}}$.

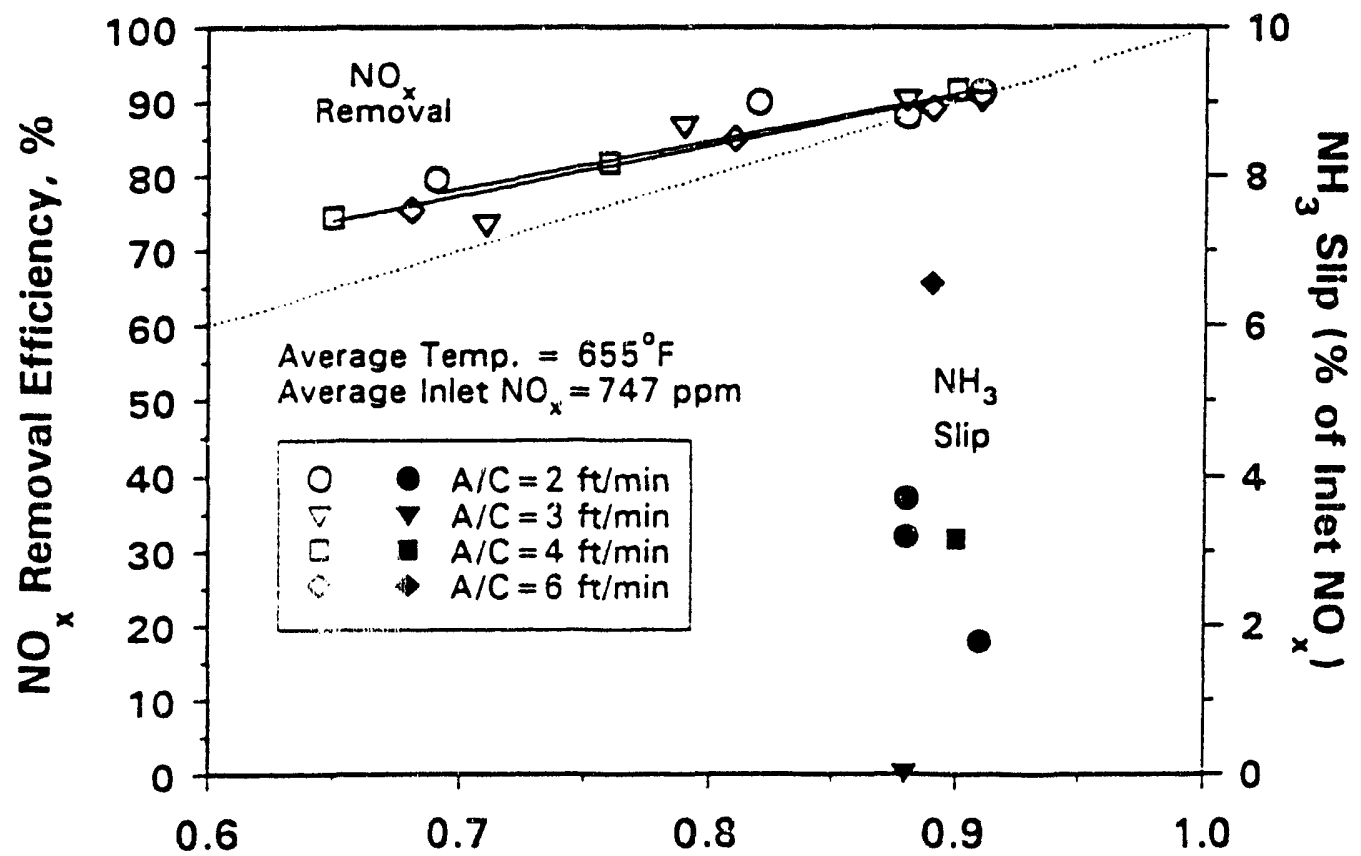

Figure 2. $\mathrm{NO}_{\mathrm{x}}$ removal efficiency as a function of air-to-cloth ratio and ammonia/NO molar ratio, PTC.BV-429. 


$$
\begin{aligned}
& 4 \mathrm{NH}_{3}+4 \mathrm{NO}+\mathrm{O}_{2} \stackrel{\text { cat. }}{\rightarrow} 6 \mathrm{H}_{2} \mathrm{O}+4 \mathrm{~N}_{2} \\
& 4 \mathrm{NH}_{3}+2 \mathrm{NO}_{2}+\mathrm{O}_{2} \stackrel{\text { cat. }}{\rightarrow} 6 \mathrm{H}_{2} \mathrm{O}+3 \mathrm{~N}_{2} \\
& \mathrm{NO}+\mathrm{NO}_{2}+2 \mathrm{NH}_{3} \stackrel{\text { cat. }}{\rightarrow} 3 \mathrm{H}_{2} \mathrm{O}+2 \mathrm{~N}_{2} \\
& 4 \mathrm{NH}_{3}+6 \mathrm{NO} \stackrel{\text { cat. }}{\rightarrow} 6 \mathrm{H}_{2} \mathrm{O}+5 \mathrm{~N}_{2} \\
& 8 \mathrm{NH}_{3}+6 \mathrm{NO}_{2} \stackrel{\text { cat. }}{\rightarrow} 12 \mathrm{H}_{2} \mathrm{O}+7 \mathrm{~N}_{2}
\end{aligned}
$$

An additior 1 test period was completed near the end of the run to determine the effect of temperarise on $\mathrm{NCl}_{\mathrm{x}}$ removal. At an air-to-cloth ratio of $2 \mathrm{ft} / \mathrm{min}$, an anmonia/ $/ \mathrm{NO}_{\mathrm{x}}$ wular ratio of 0.87 , and an average baghouse bulk gas temperature of $554^{\circ} \mathrm{F}, \mathrm{NO}_{\mathrm{x}}$ removal averaged $72 \%$, and the ammonia slip (wet chemistry measurement) was $13 \%$ of inlet $\mathrm{NO}_{\mathbf{x}}$.

Results from sulfur trioxide $\left(\mathrm{SO}_{3}\right)$ concentrations, measured using wet chemistry techniques, ranged from 0.2 to $10.7 \mathrm{ppm}$ in the flue gas, which is less than $1 \%$ of the flue gas sulfur dioxide $\left(\mathrm{SO}_{2}\right)$ concentration.

\subsubsection{PTC-BT- 430}

The data from the 100-hour test, PTC-3T-430, showed nitric oxide reduction averaged $91 \%$ at an air-to-cloth ratio of $2 \mathrm{ft} / \mathrm{min}$ (twelve bags on-line), an ammonia/ $\mathrm{NO}_{z}$ molar ratio of 0.89 (roughly 778-ppm $\mathrm{NO}_{\mathbf{x}}$ in the flue gas), and an average bulk gas baghouse temperature of $651^{\circ} \mathrm{F}$. At an air-to-cloth ratio of $4 \mathrm{ft} / \mathrm{min}$ (six bags on-line), an ammonia/ $/ \mathrm{NO}_{\mathrm{x}}$ molar ratio of 0.71 , and an average bulk gas baghouse temperature of $651^{\circ} \mathrm{F}$, nitric oxide removal averaged $75 \%$. Figure 3 plots the $\mathrm{NO}_{\mathbf{z}}$ removal efficiency and ammonia slip (as \% of inlet $\mathrm{NO}_{\mathbf{x}}$ ) as a function of ammonia/ $\mathrm{NO}_{\mathbf{x}}$ molar ratio.

Results, summarized in Figure 3, show NO reduction ranged from $75 \%$ to $91 \%$ ac air-to-cloth ratios of 2 to $6 \mathrm{ft} / \mathrm{min}$, an average baghouse bulk gas temperature of $653^{\circ} \mathrm{F}$, and an average inlet $\mathrm{NO}_{\mathrm{z}}$ concentration of $759 \mathrm{ppm}$. As with PTC-BV-429, the $\mathrm{NO}_{\mathrm{z}}$ removal data can be treated as one set. Again, indicating little or no effect on $\mathrm{NO}_{z}$ reduction due to air-to-cloth ratio. As in the previous test, the last test period completed was to determine the effect of temperature on $\mathrm{NO}_{\mathrm{x}}$ removal. At an average baghouse bulk gas temperature of $553^{\circ} \mathrm{F}$ and an ammonia/ $\mathrm{NO}_{\mathrm{x}}$ molar ratio of $0.84, \mathrm{NO}_{\mathrm{x}}$ removal averaged $80 \%$. The higher levels of $\mathrm{NO}_{\mathrm{x}}$ removal at the lower temperature for this test and the test completed during PTC-BV-429 confirm the results of the final test period of PTC-IL6-428. This would also confirm the belief that at lower temperatures during PTCII 6-426 ammonium sulfates or bisulfates were being formed, effectively lowering the $\mathrm{NO}_{x}$ removal efficiency.

Results from ammonia slip measurement using wet chemistry techniques are presented in Figure 3. Ammonia slip ranged from $3.1 \%$ of inlet $\mathrm{NO}_{x}$ at an air-to-cloth ratio of $2 \mathrm{ft} / \mathrm{min}$ to $6.2 \%$ of inlet $\mathrm{NO}_{x}$ at an air-to-cloth ratio of $6 \mathrm{ft} / \mathrm{min}$ for ammonia/NO molar ratios of nominally 0.9 . 


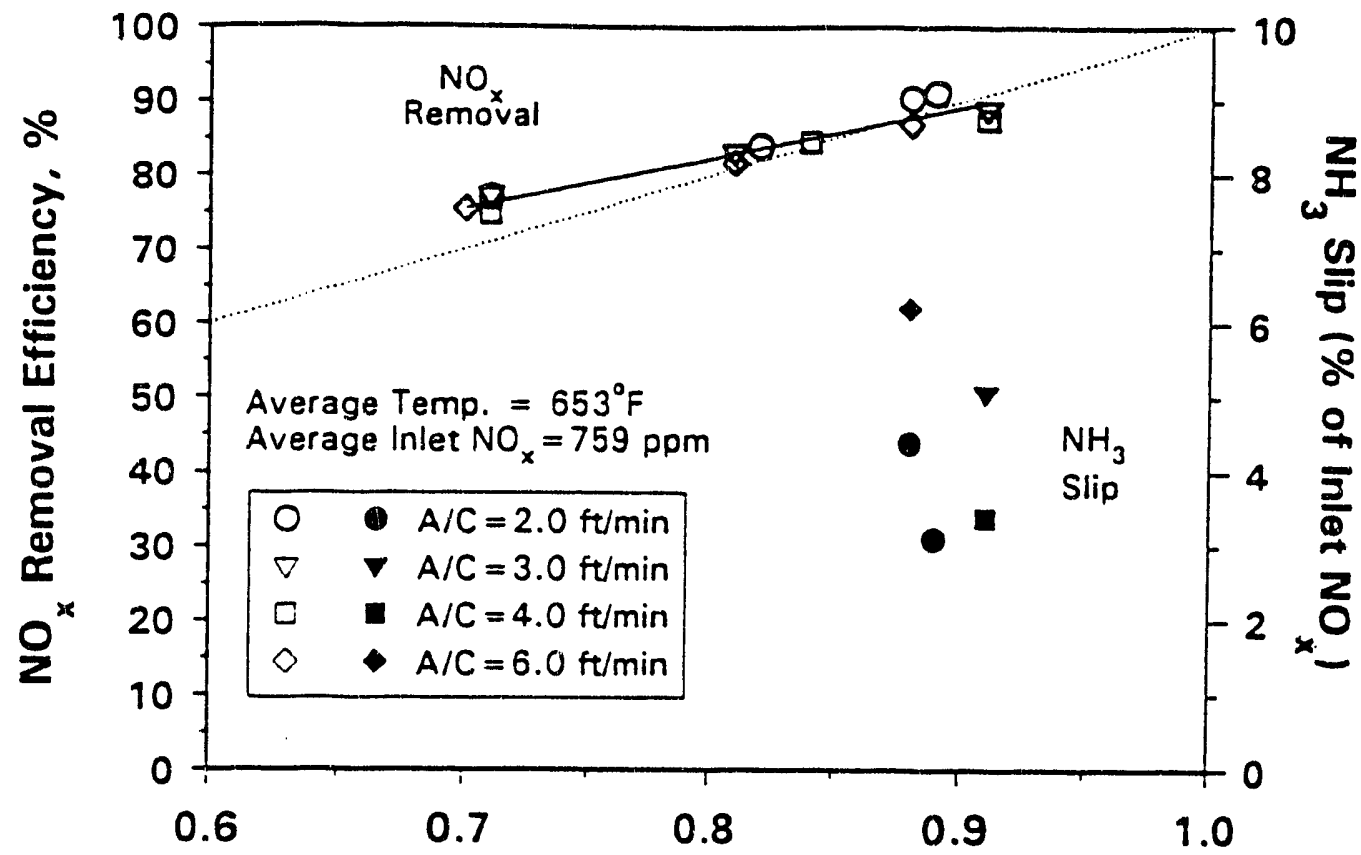

Figure 3. $\mathrm{NO}_{\mathrm{x}}$ removal efficiency as a function of air-to-cloth ratio and ammonia/NC, molar ratio, PTC-BT-430.

Sulfur trioxide measurements gave results that range from $2.1 \mathrm{ppm}$ to $7.4 \mathrm{ppm}$ in the flue gas, which for an inlet $\mathrm{SO}_{2}$ level of roughly 300 ppm, was $0.6 \%$ to $2.25 \%$ of the flue gas $\mathrm{SO}_{2}$ concentration.

\subsubsection{PTC.RO-431}

For PTC-RO-431, nitric oxide reduction averaged $94 \%$ at an air-to-cloth ratio of $2.9 \mathrm{ft} / \mathrm{min}$ (eight bags on-line), an ammonia/NO molar ratio of 0.87 (roughly $244-\mathrm{ppm} \mathrm{NO}$, in the flue gas), and an average bulk gas baghouse temperature of $653^{\circ} \mathrm{F}$. At an air-tocloth ratio of $3.9 \mathrm{ft} / \mathrm{min}$ (six bags on-line), an ammonia $\mathrm{NO}_{\mathrm{z}}$ molar ratio of 0.71 , and an average bulk gas baghouse temperature of $649^{\circ} \mathrm{F}$, nitric oxide removal averaged $83 \%$. Figure 4 plots the $\mathrm{NO}_{\mathrm{x}}$ removal efficiency and ammonia slip (\% of inlet $\mathrm{NO}_{\mathrm{z}}$ ) as a function of ammonia/ $\mathrm{NO}_{\mathbf{z}}$ molar ratio.

Results summarized in Figure 4 show two sets of $\mathrm{NO}_{\mathrm{x}}$ reduction data, unlike the previous two 100-hour pulse-jet tests, indicating an effect of air-to-cloth ratio on $\mathrm{NO}_{2}$ reduction. This may be due to either precoating the bags with dolomite or the low ash content of the oil and its effect or lack of an effect on dust cake development. The first data set shows $\mathrm{NO}_{2}$ reduction (84\% to 94\%) at air-to-cloth ratios of 2 and $3 \mathrm{ft} / \mathrm{min}$ for ammonia $\mathrm{NO}_{\mathrm{x}}$ molar ratios ranging from 0.7 to 0.9 . Data resulting from air-to-cloth ratios of 4 and $6 \mathrm{ft} / \mathrm{min}$ show $\mathrm{NO}_{\mathrm{x}}$ reduction ranging from $83 \%$ to $91 \%$ for ammonia/ $\mathrm{NO}_{\mathrm{z}}$ molar ratios of 0.7 to 0.9 . 


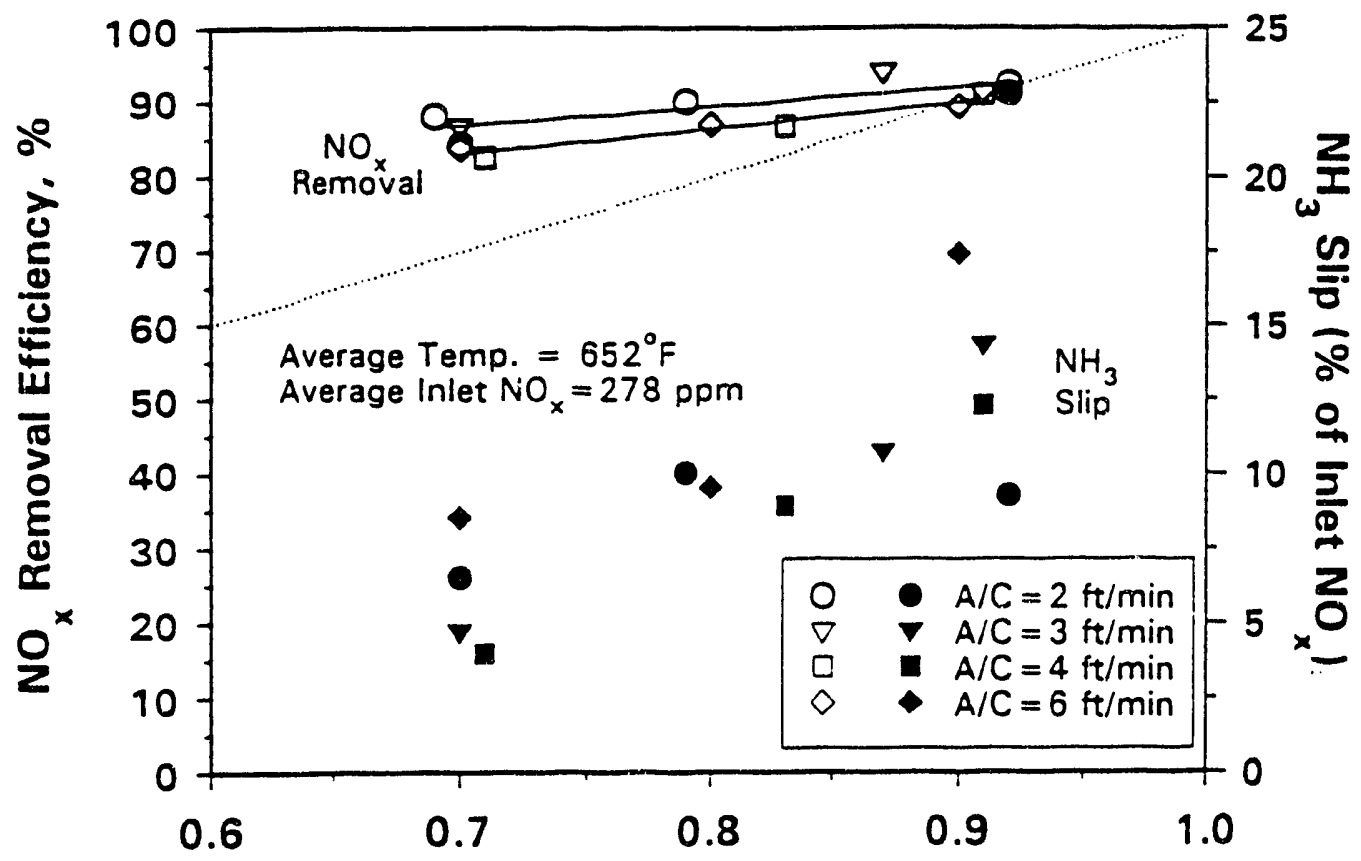

Figure 4. $\mathrm{NO}_{\mathrm{x}}$ removal efficiency as a function of air-to-cloth ratio and ammonia/NO molar ratio, PTC-RO-431.

Results from ammonia slip $r$ wrements using wet chemistry techniques are also presented in Figure 4. Ammonia slip ineasurements, made during particulate sampling periods, range from an ammonia slip of $4 \%$ of inlet $\mathrm{NO}_{\mathrm{x}}$ at an air-to-cloth ratio of $3.9 \mathrm{ft} / \mathrm{min}$, and ammonia $/ \mathrm{NO}_{\mathrm{x}}$ molar ratio 0.71 to $22.8 \%$ of inlet $\mathrm{NO}_{\mathrm{x}}$ at an air-to-cloth ratio of $1.9 \mathrm{ft} / \mathrm{min}$ and an ammonia/ $\mathrm{NO}_{\mathrm{z}}$ molar ratio of 0.92 . The ammonia slip concentrations for this 100-hour test are considerably higher based on percentage of inlet $\mathrm{NO}_{x}$ than those for previous 100-hour pulse-jet tests. However, on an absolute value basis, the ammonia slip concentrations are similar for the three 100-hour test periods. If the data represents a true difference, one explanation may be the low baghouse inlet dust loading resulting from oil-firing and the likely development of pinholes in the woven fabric that would not be bridged as a result of the low inlet ash loading. As pinholes developed, increased gas channeling would occur, resulting in increased ammonia slip.

Sulfur trioxide $\left(\mathrm{SO}_{3}\right)$ measurements were also made, and results range from $4.4 \mathrm{ppm}$ to $19.6 \mathrm{ppm}$ in the flue gas, or less than $1 \%$ to $2.3 \%$ of the flue gas $\mathrm{SO}_{2}$ concentration.

\subsubsection{PTC-BV-432}

Seventeen individual experimental periods were planned and completed during the 500-hour pulse-jet test to address the effect of ammonia/NO, molar ratio $(0.6,0.7,0.8$ and 0.9 ) at a constant air-to-cloth ratio of $3.5 \mathrm{ft} / \mathrm{min}$ (seven bags on-line). Baghouse temperature was nominally $650^{\circ} \mathrm{F}$, and flue gas was generated by firing natural gas and a Blacksville bituminous coal in the EERC pilot-scale pc-fired combustor. 
Approximately 114 hours into the run, baghouse differential pressure began to increase uncontrollably. Efforts to control differential pressure on-line by increasing cleaning frequency, pulse duration, and pulse pressure were unsuccessful; therefore, routine combustor maintenance was moved ahead one day. Inspection of the baghouse revealed one of the seven bags was not cleaning properly, as indicated by a heavy dust cake (roughly 0.5-inches thick) over the entire length of the bag. Inspection of the pulseair nozzle for this bag revealed that the nozzle was plugged by what appeared to be corrosion deposits. The piping in the pulse-air system was dismantled and thoroughly cleared prior to resuming system operation.

By effectively eliminating one bag from service due to inadequate cleaning, the effective air-tc cloth ratio was increased from 3.5 to $4 \mathrm{ft} / \mathrm{min}$. An increase in air-to-cloth ratio alone would not appear to be a sufficient explanation for the difficulty encountered with respect to controlling baghouse differential pressure. It was speculated that the bags may have become somewhat blinded. Also, the observed level of $\mathrm{NO}_{\mathrm{z}}$ reduction decreased and ammonia slip increased at the same time pressure-drop control became a problem. This change in apparent catalyst performance would be consistent with fabric blinding, the development of pinholes, and resulting gas channeling. Based on the observations made, the EERC Project Manager elected to replace this set of bags with seven bags used during the 100-hour oil-fired test (PTC-RO-431), which had performed well in terms of NOx reduction and ammonia slip and had been precoated with dolomite. Since this set of bags already had experienced one-hundred hours of operation, five-hundred hours of operation on one set of bags would still be achieved.

Figure 5 plots the $\mathrm{NO}_{\mathrm{x}}$ removal efficiency and ammonia slip (as \% of inlet $\mathrm{NO}_{\mathrm{z}}$ ) as a function of ammonia/ $\mathrm{NO}_{\mathbf{x}}$ molar ratio for the initial gas-fired test periods with the first set of bags prior to coal-firing. During the first set of gas-fired test periods, the nitric oxide reduction ranged from $76 \%$ at an ammonia/ $\mathrm{NO}_{\mathrm{x}}$ molar ratio of 0.64 to $93 \%$ at an ammonia $\mathrm{NO}_{\mathrm{z}}$ molar ratio of 0.93 . The average baghouse bulk gas temperature was $658^{\circ} \mathrm{F}$, and the inlet $\mathrm{NO}_{\mathrm{x}}$ concentration averaged $139 \mathrm{ppm}$. Ammonia slip concentrations for these test periods also indicated good bag performance, ranging from $6.8 \%$ to $19.7 \%$ of the inlet $\mathrm{NO}_{\mathbf{x}}$ ( 9 to $32 \mathrm{ppm}$ ammonia slip).

Figure 6 plots the $\mathrm{NO}_{\mathrm{x}}$ removal efficiency and ammonia slip (as \% of inlet $\mathrm{NO}_{\mathrm{x}}$ ) as a function of ammonia/NO molar ratio for the initial set of bags while firing coal. The $\mathrm{NO}_{x}$ reduction was lower than expected for the range of ammonia/ $\mathrm{NO}_{\mathrm{x}}$ molar ratios used. Nitric oxide reduction averaged $83 \%$ at an ammonia $/ \mathrm{NO}_{\mathrm{z}}$ molar ratio of $0.78,81 \%$ at an ammonia $\mathrm{NO}_{\mathrm{x}}$ molar ratio of 0.84 , and $84 \%$ at an ammonia $\mathrm{NO}_{\mathrm{x}}$ molar ratio of 0.9 . The ammonia slip concentrations while firing coal ranged from $3.0 \%$ to $19.0 \%$ of the inlet $\mathrm{NO}_{\mathrm{x}}$ concentration, with an average baghouse bulk gas temperature of $650^{\circ} \mathrm{F}$, and an average inlet $\mathrm{NO}_{\mathbf{s}}$ concentration of $887 \mathrm{ppm}$.

Figure 7 plots the $\mathrm{NO}_{\mathbf{z}}$ removal efficiency and ammonia slip (as \% of inlet $\mathrm{NO}_{\mathbf{x}}$ ) as a function of ammonia/ $\mathrm{NO}_{\mathbf{x}}$ molar ratio for the second set of gas-fired test periods. The nitric oxide reduction was similar to the results from the first set of gas firing test periods (Figure 5), except at ammonia/ $\mathrm{NO}_{\mathrm{z}}$ molar ratios of 0.9 . At the higher molar ratios, $\mathrm{NO}_{\mathrm{z}}$ reduction averaged $87 \%$, a $6 \%$ decrease. Ammonia slip concentrations also increased from the initial gas-fired test periods, ranging from $16 \%$ to $55 \%$ of inlet $\mathrm{NO}_{\mathbf{x}}$. Baghouse bulk gas temperature averaged $656^{\circ} \mathrm{F}$, and the average inlet $\mathrm{NO}_{\mathrm{z}}$ was $144 \mathrm{ppm}$. As previously discussed, the decrease in $\mathrm{NO}_{\mathrm{x}}$ removal efficiency, along with the increased ammonia slip concentrations and pressure-drop control problems, suggested blinding of the bags. 


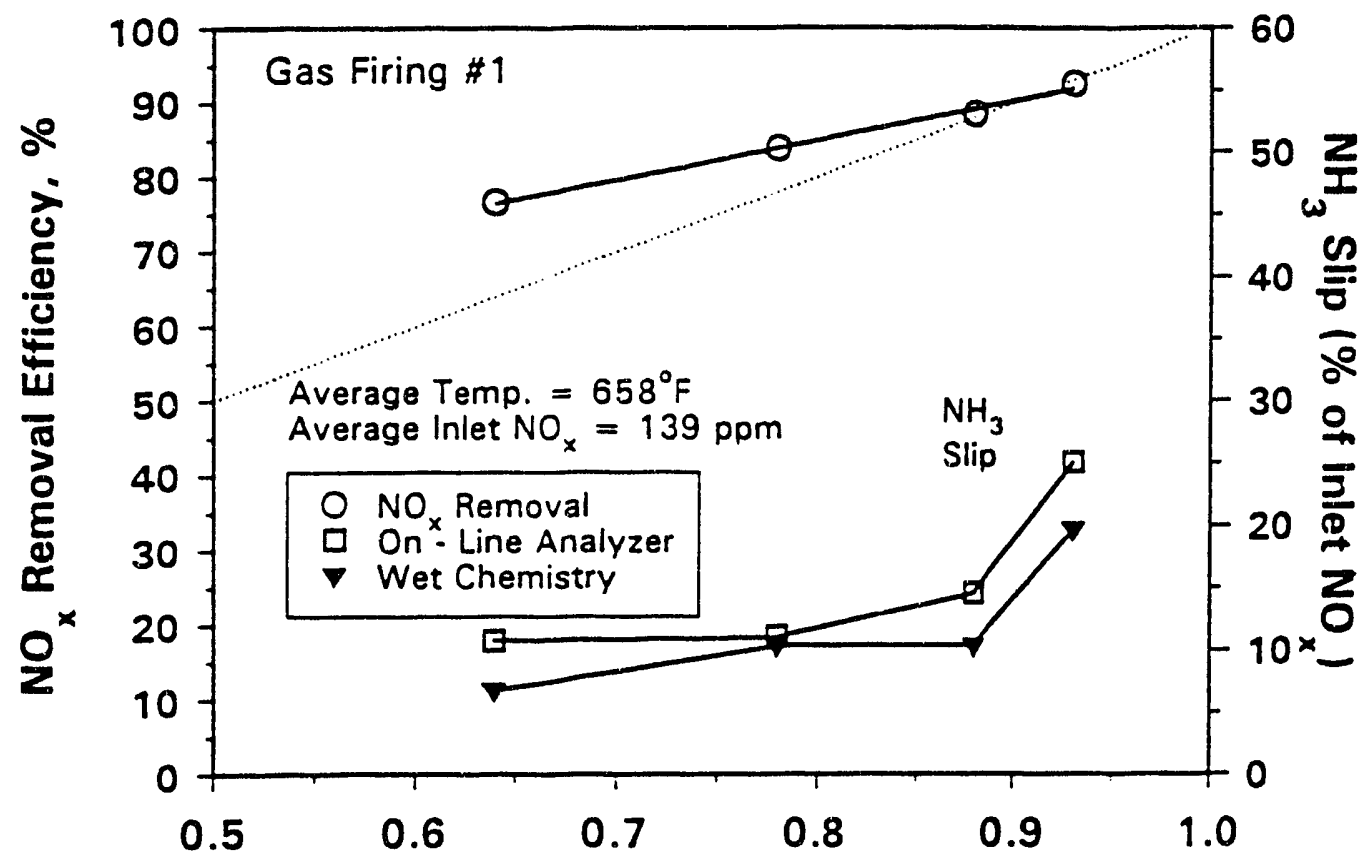

Figure 5. $\mathrm{NO}_{\mathrm{x}}$ removal efficiency as a function of air-to-cloth ratio and ammonia/NO, molar ratio, PTC-BV-432, first set of gas-fired tests.

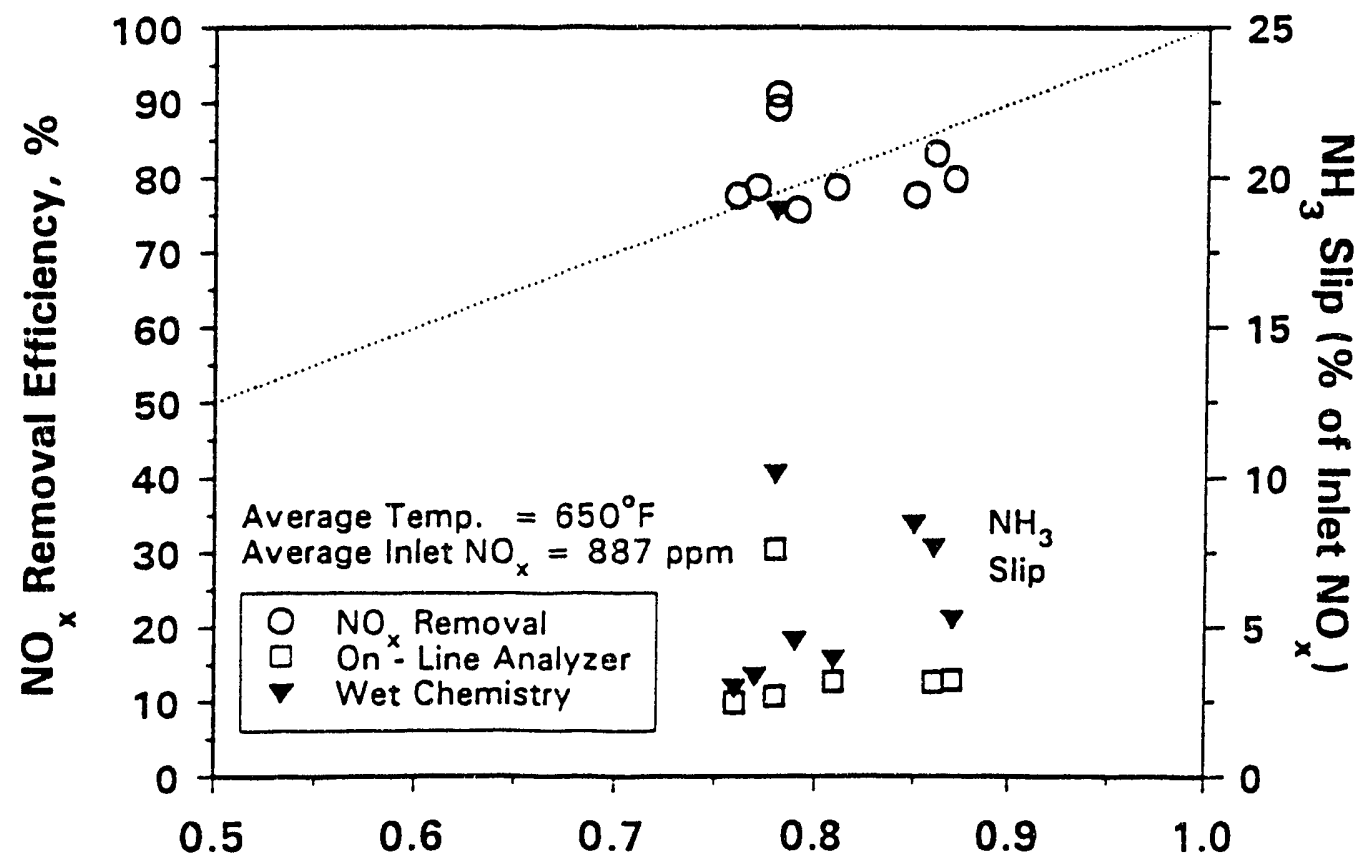

Figure 6. $\mathrm{NO}_{\mathrm{x}}$ removal efficiency as a function of air-to-cloth ratio and ammonia $\mathrm{NO}_{\mathrm{x}}$ molar ratio, PTC-BV-432, initial bags, coal-fired tests. 


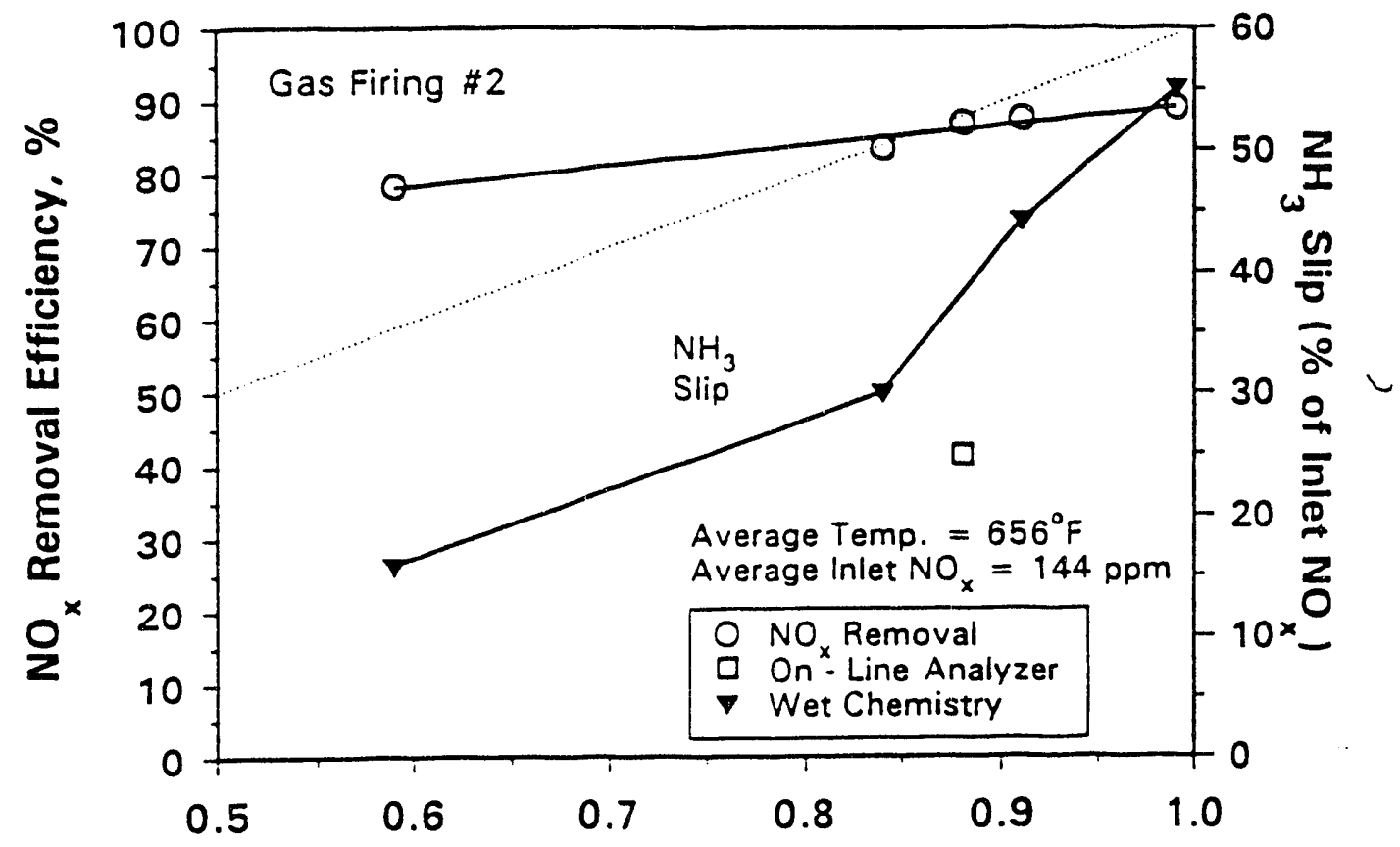

Figure 7. $\mathrm{NO}_{\mathrm{x}}$ removal efficiency as a function of air-to-cloth ratio and ammonia/NO molar ratio, PTC-BV-432, second set of gas-fired tests.

Figure 8 plots the $\mathrm{NO}_{z}$ removal efficiency and ammonia slip (as \% of inlet $\mathrm{NO}_{\mathbf{z}}$ ) as a function of ammonia/ $\mathrm{NO}_{\mathbf{z}}$ molar ratio for the second set of pulse-jet bags, during coal-fired test periods. Pressure-drop control problems occurred near the end of the 500-hour test. Data from the affected test periods is not included in Figure 8. At a nominal ammonia/NO $\mathrm{x}$ molar ratio of $0.6, \mathrm{NO}_{\mathrm{x}}$ reduction averaged $63 \%$. The average baghouse bulk gas temperature was $653^{\circ} \mathrm{F}$, and the inlet $\mathrm{NO}_{\mathrm{z}}$ concentration averaged $786 \mathrm{ppm}$. Ammonia slip concentrations were low, ranging from $1.0 \%$ to $1.6 \%$ of inlet $\mathrm{NO}_{\mathrm{x}}$. At a nominal ammonia $\mathrm{NO}_{\mathrm{x}}$ molar ratio of $0.7, \mathrm{NO}_{\mathrm{x}}$ reduction averaged $74 \%$. The average baghouse bulk gas temperature was $654^{\circ} \mathrm{F}$, and the inlet $\mathrm{NO}_{\mathbf{x}}$ concentration averaged 819 ppm. Ammonia slip concentrations ranged from $3.4 \%$ to $3.8 \%$ of inlet $\mathrm{NO}_{\mathrm{r}}$. At a nominal ammonia/ $\mathrm{NO}_{\mathrm{x}}$ molar ratio of $0.8, \mathrm{NO}_{\mathrm{x}}$ reduction averaged $81 \%$. The average baghouse bulk gas temperature was $652^{\circ} \mathrm{F}$, and the inlet $\mathrm{NO}_{\mathrm{x}}$ concentration averaged $768 \mathrm{ppm}$. The ammonia slip concentrations started at $6.8 \%$ of inlet $\mathrm{NO}_{x}$, but steadily increased to $12.5 \%$ of inlet $\mathrm{NO}_{\mathrm{x}}$ by the end of the 3 -day test period. At a nominal ammonia/ $\mathrm{NO}_{\mathrm{x}}$ molar ratio of $0.9, \mathrm{NO}_{\mathrm{x}}$ reduction averaged $85 \%$. The average baghouse bulk gas temperature was $653^{\circ} \mathrm{F}$, and the inlet $\mathrm{NO}_{\mathrm{x}}$ concentration averaged 776 ppmi. Ammonia slip concentrations ranged from $4.9 \%$ to $8.7 \%$ of inlet $\mathrm{NO}_{\mathrm{x}}$. The difference between ammonia slip concentrations at nominal ammonia/ $\mathrm{NO}_{\mathrm{x}}$ molar ratios of $0 . \varepsilon$ and 0.9 appears to be due to decreased catalyst activity with time. The data set in Figure 8 at a nominal ammonia/NO molar ratio of 0.9 was generated before the data set at 0.8 . Also, during the three-day test period at a nominal ammonia/ $\mathrm{NO}_{x}$ molar ratio of 0.8 , ammonia slip increased with time from 52 to $96 \mathrm{ppm}$. Throughout the 500-hour test, the on-line ammonia analyzer seemed to work sporadically, with ammonia slip concentrations determined by the analyzer occasionally matching those obtained from wet chemistry techniques. The analyzer worked best during gas-fired test periods. 


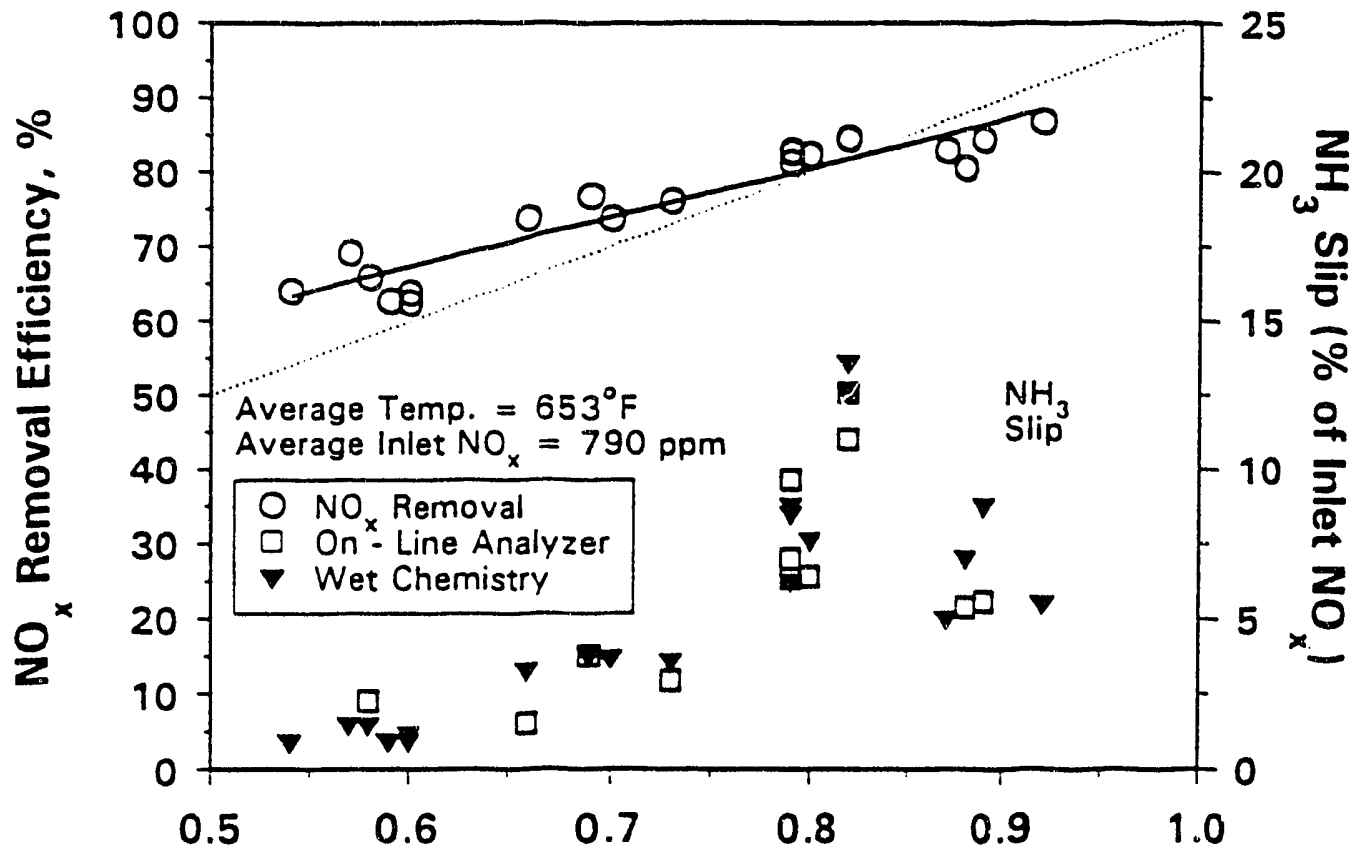

Figure 8. $\mathrm{NO}_{\mathrm{x}}$ removal efficiency as a function of air-to-cloth ratio and ammonia/ $\mathrm{NO}_{\mathbf{x}}$ molar ratio, PTC-BV-432, second set of bags, coal-fired tests.

Figures 9 and 10 plot the $\mathrm{NO}_{\mathrm{z}}$ removal efficiency and ammonia slip (as \% of inlet $\mathrm{NO}_{\mathrm{x}}$ ) as a function of ammonia/NO, molar ratio for the second set of pulse-jet bags, during the last two sets of gas-fired test periods. Nitric oxide reduction ranged from $74 \%$ to $86 \%$, at an average baghouse bulk gas temperature of $652^{\circ} \mathrm{F}$, and average inlet $\mathrm{NO}_{\mathrm{x}}$ concentration of $170 \mathrm{ppm}$. Ammonia slip concentrations ranged from $19 \%$ to $42 \%$ of inlet $\mathrm{NO}_{\mathbf{x}}$.

While the overall performance of the bags was good, it did not correspond with previous results with this fabric and the pulse-jet system. It was speculated that the decreased performance may have been due to a leak across the tube sheet of the baghouse. The leak would account for the reduced $\mathrm{NO}_{x}$ removal efficiencies, and the increased ammonia slip concentrations. Therefore, a new tube sheet was fabricated and additional test periods were completed (September 28 - October 2). Nine individual test periods were complete \pm , four firing natural gas (ammonia/ $\mathrm{NO}_{\mathrm{z}}$ molar ratios of $0.6,0.7,0.8$, and 0.9 ) and five firing Blacksville bituminous coal (ammonia $\mathrm{NO}_{\mathrm{x}}$ molar ratios of $0.6,0.7$, 0.8 (twice), and 0.9).

Figure 11 plots the $\mathrm{NO}_{\mathbf{z}}$ removal efficiency and ammonia slip (as \% of inlet $\mathrm{NO}_{\mathbf{x}}$ ) as a function of ammonia $/ \mathrm{NO}_{x}$ molar ratio for the additional natural gas-fired tests. It can be seen that $\mathrm{NO}_{\mathrm{x}}$ removal efficiency was poor, ranging from $45 \%$ at an ammonia/NO . molar ratio of 0.58 to $61 \%$ at an ammonia/ $\mathrm{NO}_{\mathrm{x}}$ molar ratio of 0.89 . Ammonia slip concentrations ranged from $8 \%$ to $13 \%$ of inlet $\mathrm{NO}_{\mathrm{x}}$, with an average inlet $\mathrm{NO}_{\mathrm{x}}$ concentration of $190 \mathrm{ppm}$, and an average baghouse bulk gas temperature of $657^{\circ} \mathrm{F}$. 


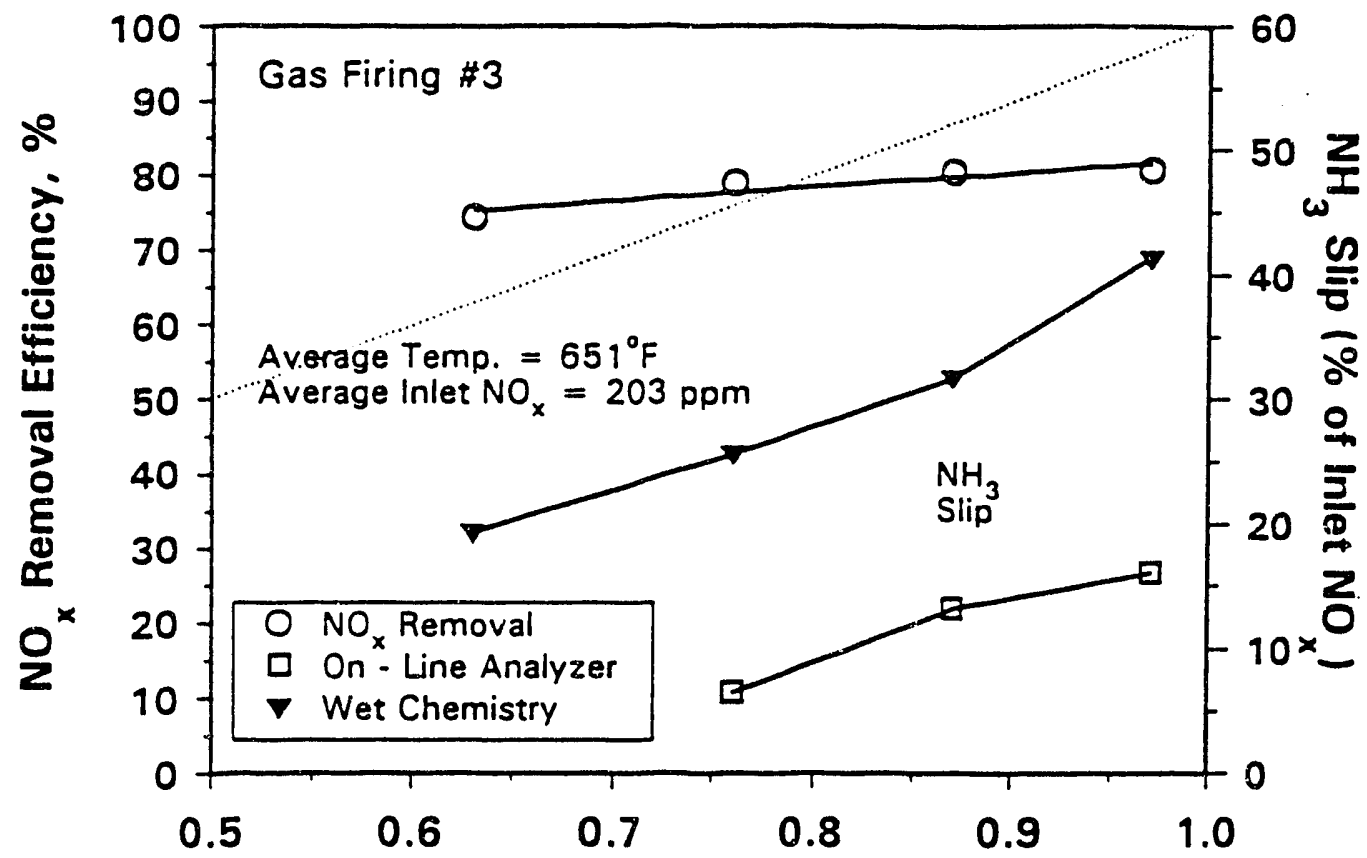

Figure 9. $\mathrm{NO}_{\mathrm{z}}$ removal efficiency as a function of air-to-cloth ratio and ammonia/NO, molar ratio, PTC-BV-432, third set of gas-fired tests.

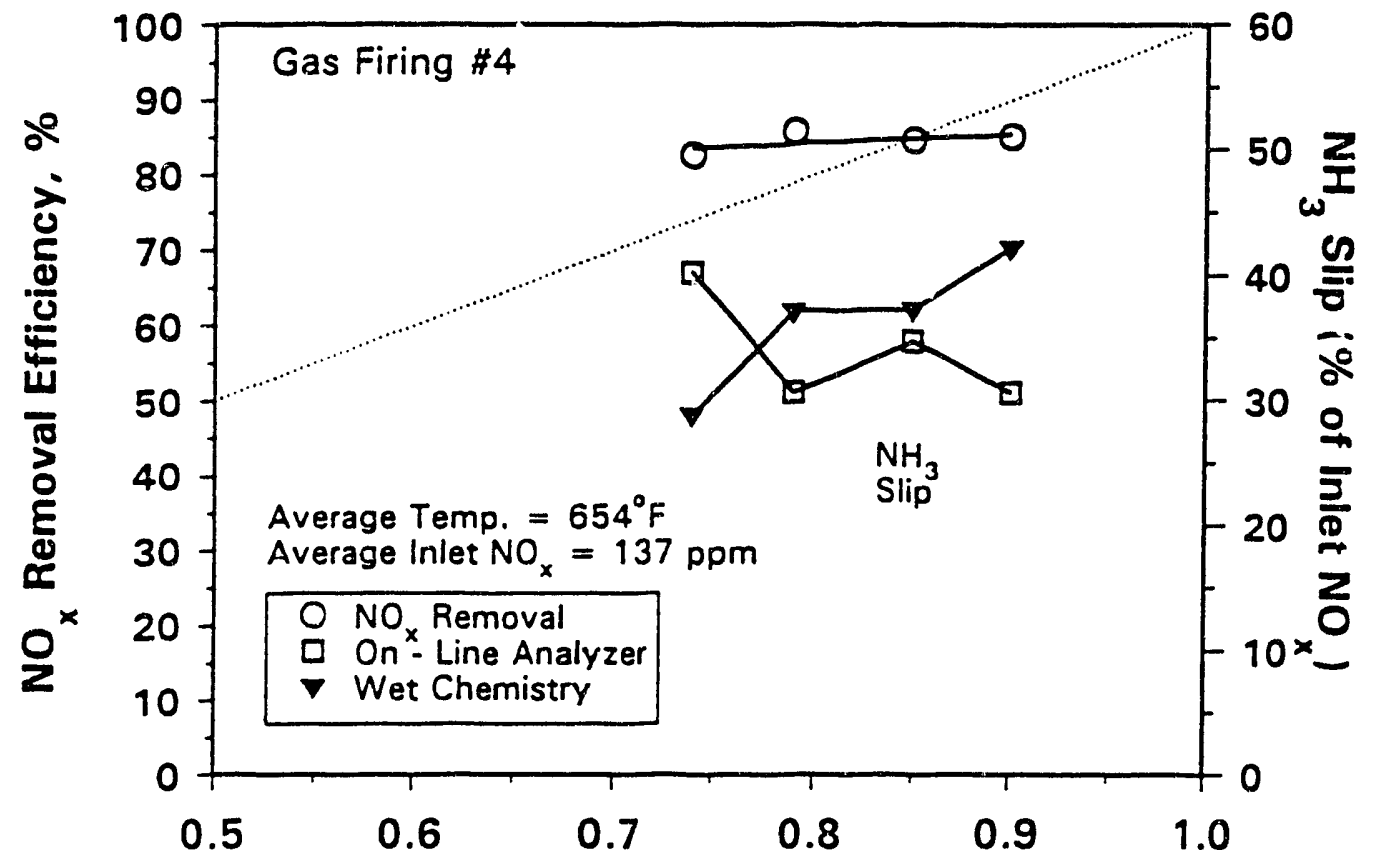

Figure 10. $\mathrm{NO}_{\mathrm{x}}$ removal efficiency as a function of air-to-cloth ratio and ammonia/ $\mathrm{NO}_{\mathrm{x}}$ molar ratio, PTC-BV.432, fourth set of gas-fired tests. 


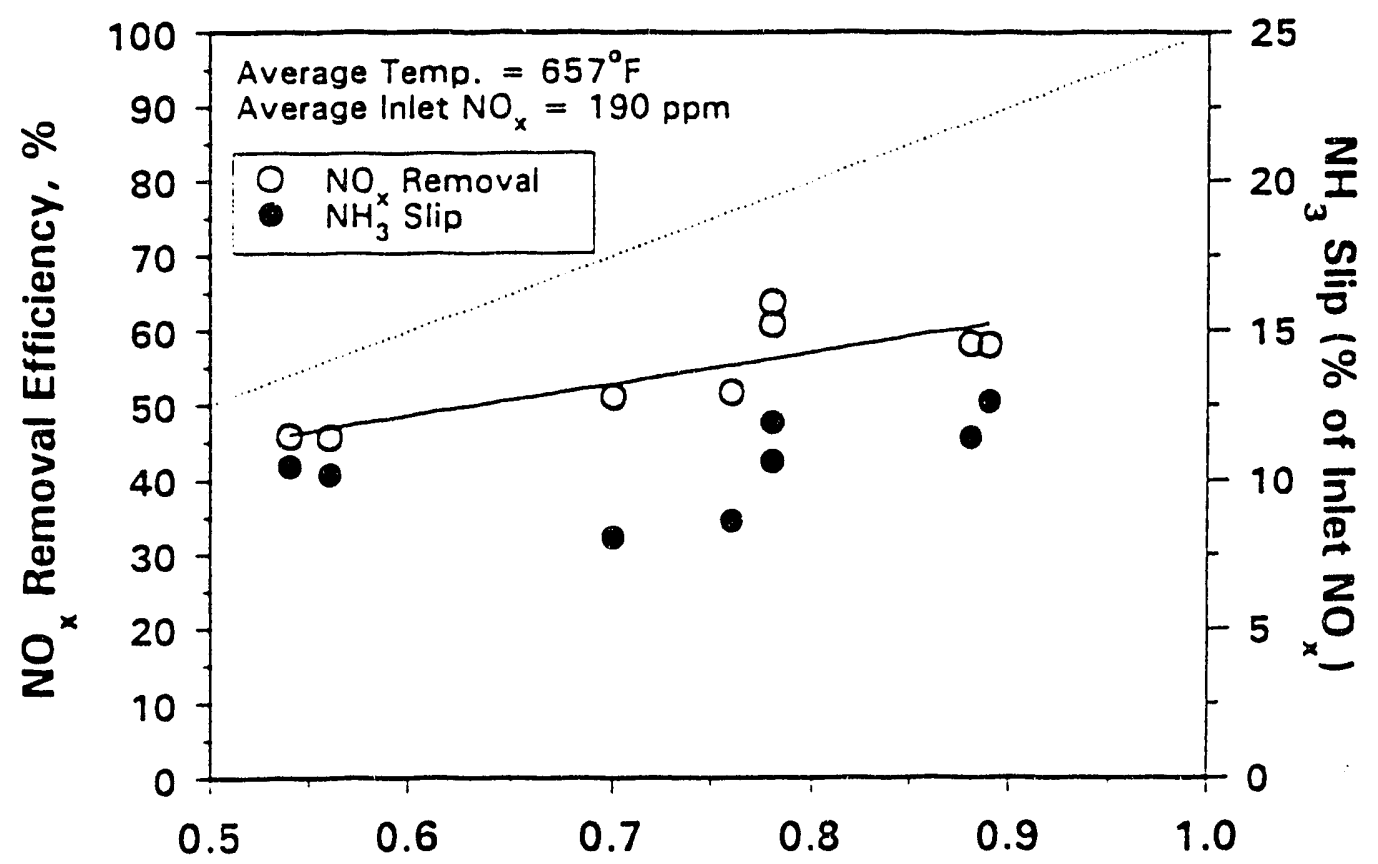

Figure 11. $\mathrm{NO}_{3}$ removal efficiency as a function of air-to-cloth ratio and ammonia/NO, molar ratio, PTC-BV-432, additional gas-fired tests.

Figure 12 plots the $\mathrm{NO}_{\mathrm{x}}$ removal efficiency and ammonia slip (as \% of inlet $\mathrm{NO}_{\mathrm{x}}$ ) as a function of ammonia $\mathrm{NO}_{\mathrm{x}}$ molar ratio for the additional coal-fired test periods. Although the $\mathrm{NO}_{\mathrm{x}}$ removal efficiency increased, it was still lower than expected, ranging from $65 \%$ at an ammonia/ $\mathrm{NO}_{\mathrm{x}}$ molar ratio of 0.6 to $80 \%$ at an ammonia/NO molar ratio of 0.9 . Ammonia slip concentrations were high, ranging from $5 \%$ to $22 \%$ of inlet $\mathrm{NO}_{\mathrm{x}}$. The baghouse bulk gas temperature averaged $659^{\circ} \mathrm{F}$, and the inlet $\mathrm{NO}_{\mathrm{x}}$ concentration averaged 744 ppm.

Figure 13 plots $\mathrm{NO}_{\mathrm{x}}$ removal efficiency as a function of time for the pulse-jet filter bags used during PTC-RO-431 and the second part ( 400 hours) of PTC-BV-432. From the figure it can be seen performance decreased with time at ammonia $/ \mathrm{NO}_{\mathbf{x}}$ molar ratios of $0.7,0.8$, and 0.9 .

The absence of a similar trend at an ammonia $\mathrm{NO}_{\mathrm{x}}$ molar ratio of 0.6 is most likely due to the limited number of data points generated. Inspection of the bags, after the additional gas- and coal-fired test periods were completed, revealed material caked to the bottom of six of the bags in roughly 3-inch by 14-inch strips. Samples of the material were submitted for analysis in order to determine their chemical characteristics. X-ray diffraction (XRD) analysis showed that most of the material was dolomite $\left(\mathrm{CaCO}_{3} / \mathrm{MgCO}_{3}\right)$ with small quantities of quartz $\left(\mathrm{SiO}_{2}\right)$, anhydrite $\left(\mathrm{CaSO}_{\downarrow}\right)$, and possibly hexahydrite $\left(\mathrm{MgSO}_{4} \cdot 6 \mathrm{H}_{2} \mathrm{O}\right)$. Since these bags had been originally coated with dolomite for the oil-fired test, the results are not surprising. The presence of a small amount of $\mathrm{CaSO}_{4}$ would be expected due to the high $\mathrm{SO}_{2}$ concentration in the flue gas, and the quartz represents a significant pol ion of the fly ash. The fact that a small amount of $\mathrm{MgSO}_{4} \cdot 6 \mathrm{H}_{2} \mathrm{O}$ may have been present indicates that the bottom foot of each bag may have experienced a small amount of condensed moisture. 


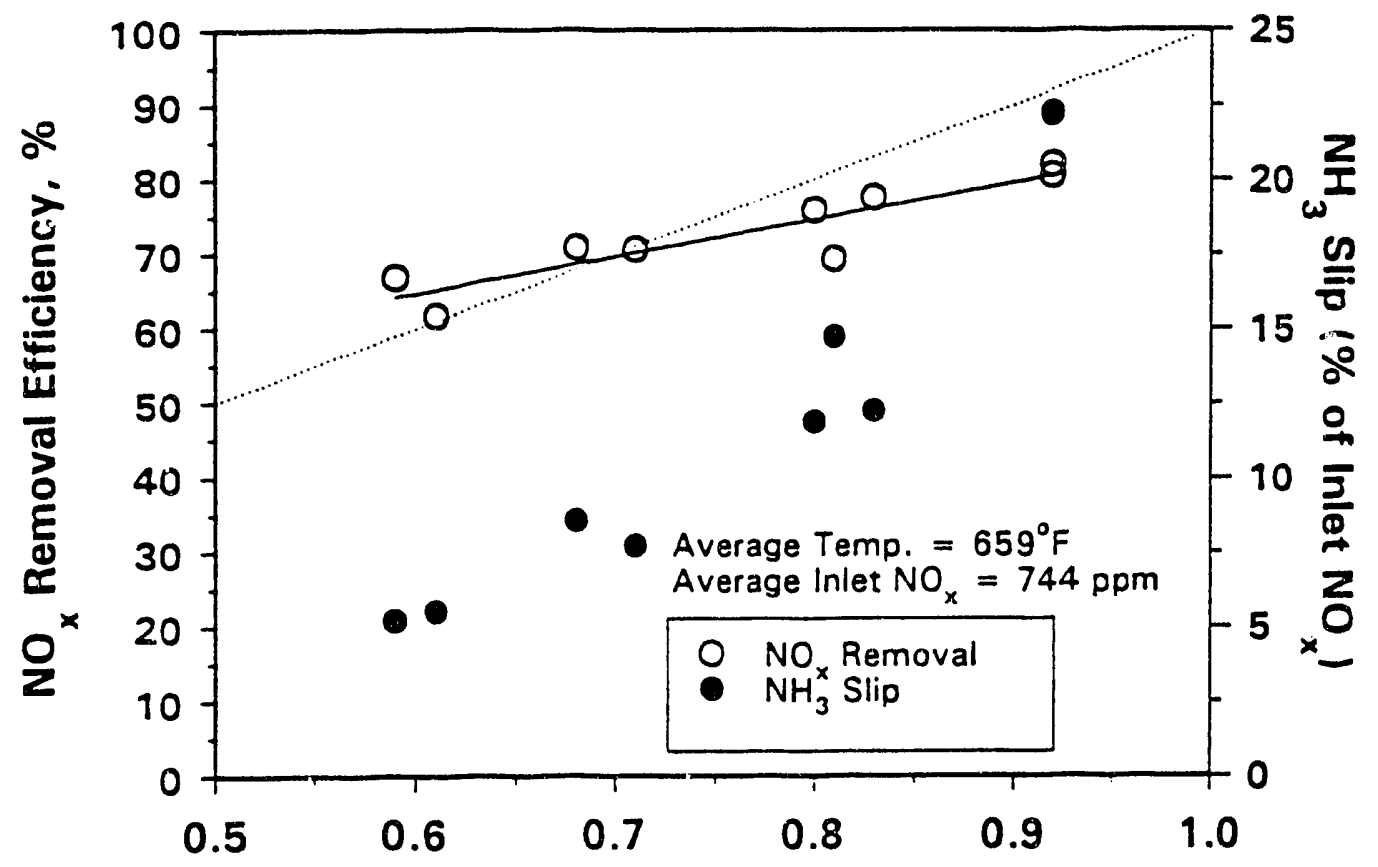

Figure 12. $\mathrm{NO}_{\mathrm{x}}$ removal efficiency as a function of air-to-cloth ratio and ammonia/NO, molar ratio, PTC-BV-432, additional coal-fired tests.

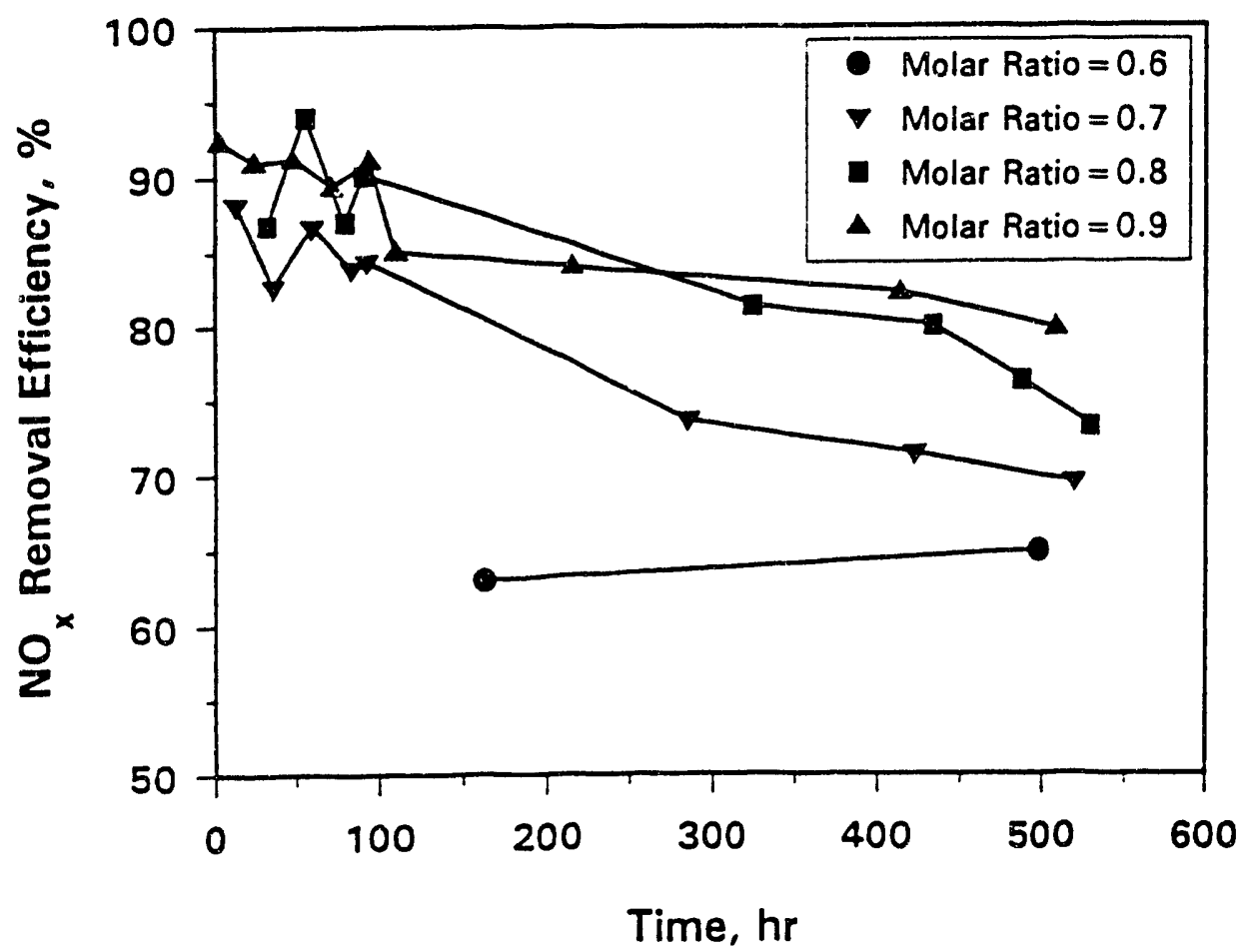

Figure 13. NO removal efficiency as a function of time, PTC-RO-431 and PTC-BV-432. 
The caked ash depnsits previously described would be consistent with limited fabric exposure to moisture. Since the patches of caked ash were small and limited to the bottom of the bags, it is not likely that the moisture came from the pulse-air system. Operating data and logs do not indicate any excursions that would have led to moisture entering the baghouse. One possible explanation is that during initial combustor heatup on natural zas, water is condensed in the flue gas piping. Condensed water is removed from the system through various drip legs. Flue gas flow is not diverted through the baghouse until the drip legs are dry and the desired baghouse inlet temperature is achieved. The possibility exists that if one of the drip legs became plugged with ash, moisture could be collected, but not drained from the system. When flue gas flow is diverted through the baghouse, condensed water could be rarried into the baghouse by the flue gas. In this event, the condensed water would most ilikely come in contact with the bottom of each bag, but would dry quickly due to the high flue gas temperature, $650^{\circ} \mathrm{F}$. If moisture is the explanation for the caked ash on the bottom of six of the seven bags, and the end result was reduced catalyst reactivity, the small percentage of fabric area affected would not explain the overall level of decreased catalyst performance observed.

Another possibility that needs to be considered is that the particular set of bags evaluated had ultimately been installed and removed from the baghouse on three separate occasions. The amourit of physical handling experienced by the bags may have also contributed to reduced performance with time. In a commercial installation, bag handling would generally be limited to iritial installation and bag removal after a failure or significant decrease in performance.

A bag, from the set tested, was cut in half lengthwise and samples were submitted for vanadium and surface area analysis to determine if there was a loss of catalyst from the bags. The surface area for a heat-treated, unused sample was $10.81 \mathrm{~m}^{2} / \mathrm{g}$ compared to the used sample, which was only $2.35 \mathrm{~m}^{2} / \mathrm{g}$. This indicates a $78 \%$ decrease in surface area. Figure 14 compares the current $\mathrm{NO}_{\mathrm{x}}$ removal and surface area data to a relationship developed from previous bench-scale data. The trend of decreasing $\mathrm{NO}_{\mathrm{x}}$ removal efficiency corresponds to the decrease due to decreasing surface area. This was also supported by the vanadium analysis, which showed a decrease of $15 \%$ for the used bags (5700-5900 ppm) when compared to new heat-treated fabric (6800 ppm). Further analysis of fabric samples for vanadium concentration and surface area are in progress in order to establish statistical significance for variability observed in surface area and vanadium concentration data.

Sulfur trioxide $\left(\mathrm{SO}_{3}\right)$ measurements were made with ammonia injection turned off during P'C.BV.432, and the concentrations ranged from 0.2 to $11.5 \mathrm{ppm}$, or $0.01 \%$ to $0.69 \%$ of the flue gas $\mathrm{SO}_{2}$ concentration. Figure 15 plots the outlet $\mathrm{SO}_{3}$ concentration and the inlet $\mathrm{SO}_{2}$ coricentration as a function of time. The first five $\mathrm{SO}_{3}$ concentration values are from the first set of pulse-jet bags used during PTC-BV -432 . With these points removed, $\mathrm{SO}_{3}$ concentration was relatively constant, averaging $1.6 \mathrm{ppm}$. The one item to keep in mind is that the second set of bags had already seen 100 hours of service during PTC-RO-431 and measured $\mathrm{SO}_{3}$ concentrations ranged from 4 to $20 \mathrm{ppm}$. Therefore, the general trend is toward lower $\mathrm{SO}_{3}$ concentration with time, which also indicates decreasing catalyst reactivity with time. 


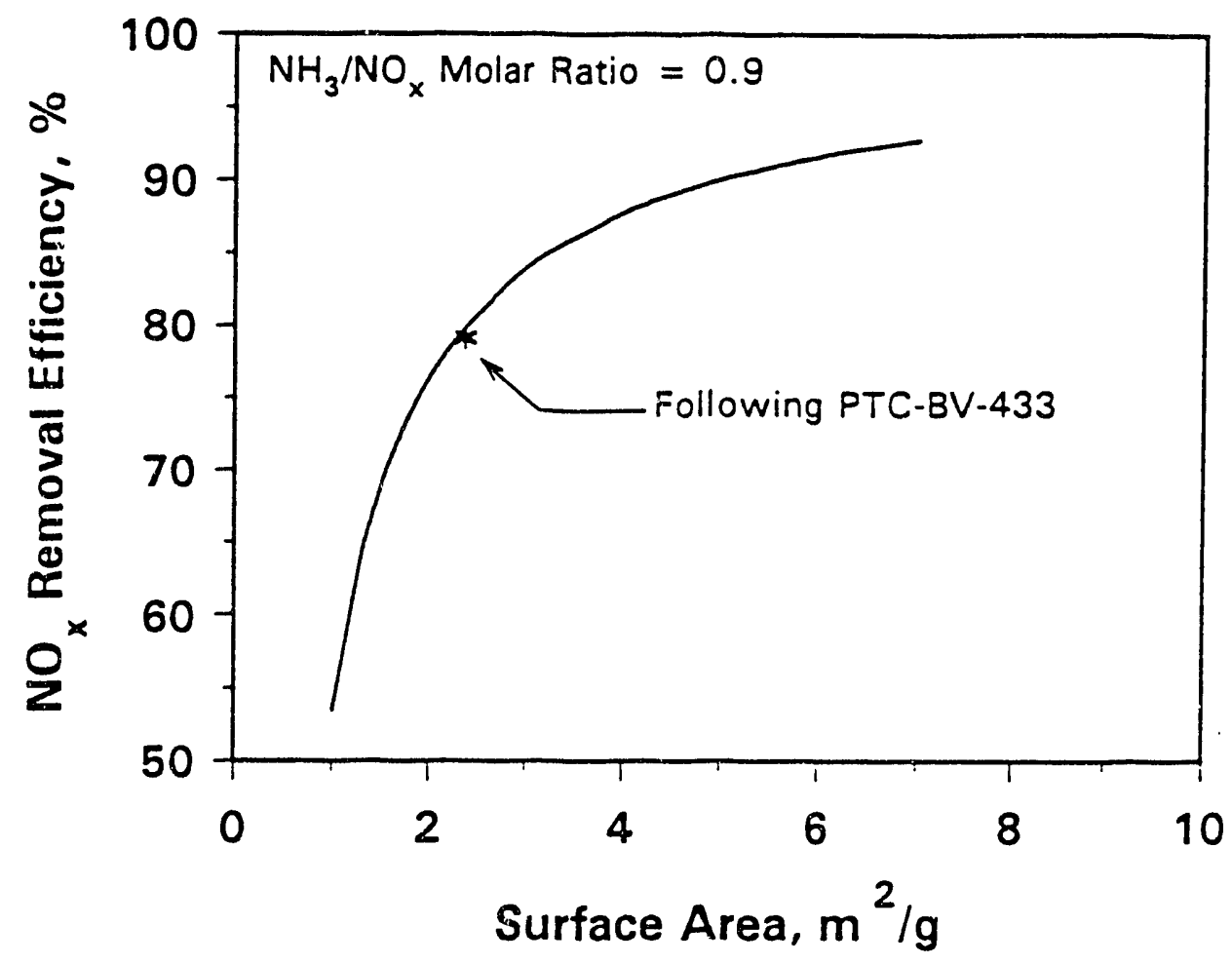

Figure 14. $\mathrm{NO}_{\mathrm{x}}$ removal efficiency as a function of surface area, bench-scale data versus PTC-BV-432.

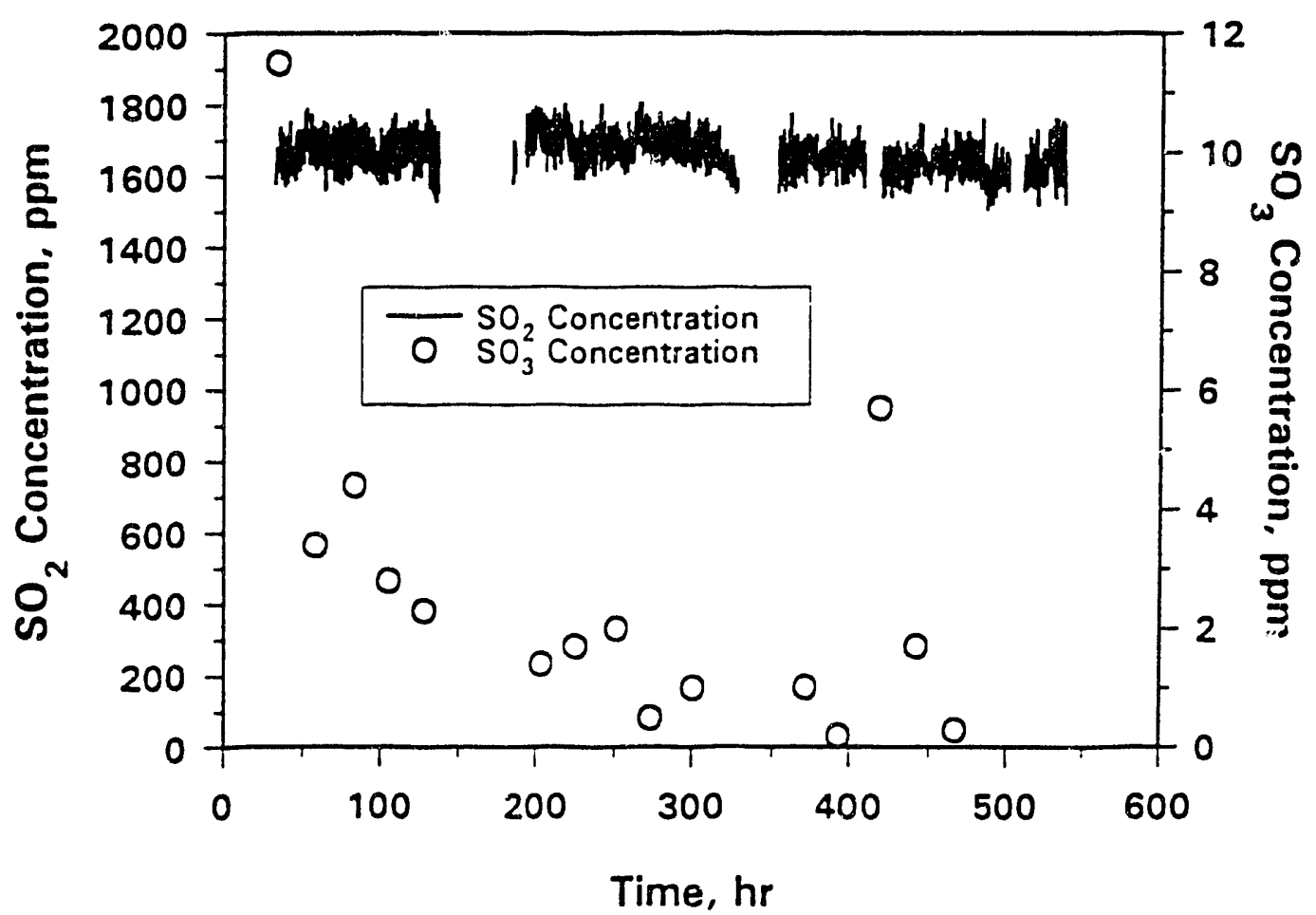

Figure 15. $\mathrm{SO}_{2}$ and $\mathrm{SO}_{3}$ concentrations as a function of time, PTC-BV-432. 


\subsubsection{Particulate Collectior}

Pressure drop and particulate emissions data were also collected during each test. Particulate measurements were made using Environmental Protection Agency (EPA) Method 5, multicyclone, and an aerodynamic particle sizer (APS). A discussion of these results are presented in the following paragraphs.

\subsubsection{PTC.BV.429}

For test PTC-BV-429, respirable inass data were collected at air-to-cloth ratios of 2 , 3,4 , and $6 \mathrm{ft} / \mathrm{min}$. Due to continuous on-line and occasional off-line cleaning of the pulse-jet bags, the respirable mass data was not plotted as a function of time. At an airto-cloth ratio of $2 \mathrm{ft} / \mathrm{min}$ the respirabl mass quickly decreased from $30 \mathrm{mg} / \mathrm{m}^{3}$ for clean fabric to $3 \times 10^{-4} \mathrm{mg} / \mathrm{m}^{3}$. At an air-to cloth ratio of $3 \mathrm{ft} / \mathrm{min}$ the respirable mass ranged from roughly $8 \times 10^{-5}$ to $2 \mathrm{mg} / \mathrm{m}^{2}$. At an air.to-cloth ratio of $4 \mathrm{ft} / \mathrm{min}$ the respirable mass ranged from roughly $4 \times 10^{-1}$ to $7 \mathrm{mg} / \mathrm{m}^{3}$. At an air-to-cloth ratio of $6 \mathrm{ft} / \mathrm{min}$ the respirable mass ranged from roughly $7 \times 10^{-2}$ to $4 \mathrm{mg} / \mathrm{m}^{3}$.

Emissions in the $2 \cdot$ to $7 \cdot \mathrm{mg}^{\prime} \mathrm{m}^{3}$ range represent emission spikes due to cleaning cycles. Tables 3 and 4 summarize EPA Method 5 and multicyclone particulate-sampling data, respectively, for PTC-BV-429. The particulate collection efficiency ranged from $99.4 \%$, at an air-to-cloth ratio of $6 \mathrm{ft} / \mathrm{min}$ with ammonia injection, to $>99.9 \%$, at all air-tocloth ratios with ammonia injection turned off. With ammonia injection on, ammonia slip results in the formation of sulfates in the sample train, which increases the measured outlet mass loading, reducirg the calculated particulate collection efficiency. The inlet mass loading to the fabric filter was nominally $1.9 \mathrm{gr} / \mathrm{scf}$.

In addition to particulate collection efficiency, the operational pressure drop across the bags was continuously mionitored. At air-to-cloth ratios of 2,3 and $4 \mathrm{ft} / \mathrm{min}$, the pulsejet bags were cleaned off-line at 2 hour intervals to maintain a baghouse differential pressure of less than 6 inches W.C. At $6 \mathrm{ft} / \mathrm{min}$ it was necessary to clean the bags continuously on-line and roughly every hour off-line to maintain a baghouse differential pressure drop of less than 7 inches W.C. Figure 16 plots the pressure drop as a function of time, based on the off-line cleaning data.

\subsubsection{PTC-BT-430}

For test PTC.BT-430. respirable mass data was collected at air-to-cloth ratios of 2, 3, 4 , and $6 \mathrm{ft} / \mathrm{min}$. Due to continuous on-line and occasional off-line cleaning of the pulse-jet bags, the respirable mass data was not plotted as a function of time. At an air-to-cloth ratio of $2 \mathrm{ft} / \mathrm{min}$ the respirable mass ranged from roughly $5 \times 10^{-4}$ to $3 \mathrm{mg} / \mathrm{m}^{2}$. At an air. to-cloth ratio of $3 \mathrm{ft} / \mathrm{m}^{\text {in }}$ the respirable mass ranged from roughly $7 \times 10^{-1}$ to $0.5 \mathrm{mg} / \mathrm{m}^{3}$. At an air-to-cloth ratio of $4 \mathrm{ft} / \mathrm{min}$ the respirable mass ranged from roughly $2 \times 10^{-3}$ to 9 $\mathrm{mg} / \mathrm{m}^{3}$. At an air-to-cloth ratio of $6 \mathrm{ft} / \mathrm{min}$ the respirable mass ranged from roughly $2 \mathrm{x}$ $10^{-2}$ to $1 \mathrm{mg}^{3}$. Tables 3 and 5 summarize EPA Method 5 and multicyclone particulatesampling data for PTC-BV- +29 . Particulate collection efficiency ranged from roughly $99.9 \%$ to $>99.9 \%$ at all air-to-cloth ratios, with the ammonia injection on or off. This is consistent with the particulate collection data from PTC-BT-424. The high alkali content of the Black Thunder fly ash. would be expected to control $\mathrm{SO}_{3}$ concentration in the flue gas minimizing the potential for the formation of ammonia/sulfur products in the sample system. The inlet dust loading averaged $1.8 \mathrm{gr} / \mathrm{scf}$. 
TABLE 3

Particulate-Sampling Data for Pilot-Scale Catalytic Fabric Filter Tests

\begin{tabular}{|c|c|c|c|c|}
\hline Test Date & Inlet, gr/scf & Outlet, gr/scf & $\% \mathrm{H}_{2} \mathrm{O}$ & Efficiency ${ }^{c}, \%$ \\
\hline \multicolumn{5}{|c|}{ Shakedown } \\
\hline $08-28-91$ & 3.4774 & - & 10.5 & - \\
\hline $08-28-91$ & $\ldots$ & 0.0015 & 9.1 & 99.96 \\
\hline $08-28-91$ & 2.6611 & $\cdots$ & 10.2 & - \\
\hline \multicolumn{5}{|c|}{ PTC-IL6-408 } \\
\hline 11.18 .91 & 3.1843 & - & 10.7 & $\ldots$ \\
\hline $11-18-91$ & - & 0.0028 & 8.1 & 99.91 \\
\hline $11 \cdot 18 \cdot 91$ & $\cdots$ & 0.0036 & 7.8 & 99.89 \\
\hline $11 \cdot 19 \cdot 91$ & $2.7771^{a}$ & -- & 5.2 & -.. \\
\hline $11-19-91$ & ..- & 0.0008 & 7.5 & 99.97 \\
\hline $11-19-91$ & 2.8891 & -.- & 7.6 & - \\
\hline $11-20-91$ & 3.109 & - & 9.6 & $\cdots$ \\
\hline $11-20-91$ & - & 0.0065 & 7.9 & 99.79 \\
\hline $11.21-91$ & 3.3357 & $\cdots$ & 9.1 & $\cdots$ \\
\hline $11-21-91$ & $2.4938^{\circ}$ & - & 3.9 & $\ldots$ \\
\hline $11.21-91$ & - & 0.0014 & 7.6 & 99.58 \\
\hline $11-22-91$ & 3.191 & - & 8.1 & - \\
\hline $11-22-91$ & - & 0.0008 & 7.6 & 99.97 \\
\hline \multicolumn{5}{|c|}{ PTC-II6-414 } \\
\hline $01-13-92$ & 3.5102 & - & 9.1 & - \\
\hline $01-13-92$ & - & 0.0127 & 6.6 & 99.64 \\
\hline $01-13-92$ & - & 0.0076 & 5.6 & 99.78 \\
\hline $01 \cdot 14-92$ & $\ldots{ }^{b}$ & -.- & $\cdots$ & -- \\
\hline $01-14-92$ & 2.7997 & $\ldots$ & 9.5 & $\cdots$ \\
\hline $01 \cdot 14-92$ & - & 0.1099 & 6.9 & 96.07 \\
\hline \multicolumn{5}{|c|}{ PTC-M6-415 } \\
\hline $02-03-92$ & 3.2273 & -.- & 7.5 & -- \\
\hline $02 \cdot 03-92$ & $\ldots$ & 0.0033 & 6.8 & 99.90 \\
\hline $02-04.92$ & 2.7413 & $\ldots$ & 8.5 & $\cdots$ \\
\hline $02-04-92$ & $\ldots$ & 0.007 & 6.5 & 99.74 \\
\hline $02 \cdot 04-92$ & 3.1062 & -.. & 8.5 & -.. \\
\hline $02-04-92$ & $\cdots$ & 0.0134 & 8.3 & 99.57 \\
\hline
\end{tabular}

- Multicyclone sampling

bampling error

- Ammonia injection on

d Damaged bag

- Ammonia injection off 
TABLE 3 (continued)

\begin{tabular}{|c|c|c|c|c|}
\hline Test Date & Inlet, gr/scf & Outlet, gr/scf & $\% \mathrm{H}_{2} \mathrm{O}$ & Efficiency ${ }^{\circ}, \%$ \\
\hline \multicolumn{5}{|c|}{ PTC-IL6-415 (continued) } \\
\hline $02-05-92$ & 2.5742 & - & 7.7 & - \\
\hline ก?.05-92 & -. & 0.0182 & 7.9 & 99.29 \\
\hline $02 \cdot 05-92$ & $2.3597^{\circ}$ & - & 6.7 & - \\
\hline $02.06-92$ & 3.0250 & - & 7.6 & - \\
\hline $02-06-92$ & .. & 0.0122 & 6.2 & 99.60 \\
\hline 02.07 .92 & 2.7319 & - & 6.3 & ... \\
\hline $02.07-92$ & -. & 0.0250 & 6.3 & 99.08 \\
\hline $02 \cdot 07.92$ & $2.7653^{\mathrm{a}}$ & - & 7.8 & ..- \\
\hline \multicolumn{5}{|c|}{ PTC-II6-416 } \\
\hline $02 \cdot 10 \cdot 92$ & 2.6814 & - & 8.5 & -. \\
\hline $02 \cdot 10 \cdot 92$ & ..- & 0.0114 & 7.5 & 99.57 \\
\hline $02-10-92$ & $\ldots$ & 0.0069 & 8.2 & 99.74 \\
\hline $02-11-92$ & 2.8368 & - & 7.6 & -. \\
\hline 02.11 .92 & $\ldots$ & 0.0170 & 5.5 & 99.40 \\
\hline 02.11 .92 & $3.3836^{\mathrm{a}}$ & - & 6.3 & - \\
\hline $02-12.92$ & 2.8452 & - & 7.8 & - \\
\hline 02.12 .92 & $\cdots$ & 0.0138 & 5.7 & 99.52 \\
\hline \multicolumn{5}{|c|}{ PTC-L6-417 } \\
\hline $02-24-92$ & 3.0147 & - & 9.3 & - \\
\hline $02-24-92$ & $\ldots$ & 0.0154 & 7.9 & 99.49 \\
\hline $02-24-92$ & $\ldots$ & 0.0186 & 7.3 & 99.38 \\
\hline $02 \cdot 25-92$ & 2.8668 & - & 7.3 & - \\
\hline $02-25-92$ & $\cdots$ & 0.0178 & 7.7 & 99.38 \\
\hline $02 \cdot 25-92$ & $2.8518^{\circ}$ & -- & 4.6 & $\cdots$ \\
\hline $02-26-92$ & 2.9464 & - & 8.0 & - \\
\hline $02 \cdot 26-92$ & -- & 0.0182 & 8.1 & 99.37 \\
\hline $02 \cdot 26-92$ & $\cdots$ & 0.0338 & 8.1 & 99.85 \\
\hline $02 \cdot 27-92$ & 3.0054 & - & 13.6 & $\cdots$ \\
\hline $02 \cdot 27 \cdot 92$ & $\cdots$ & 0.0322 & 7.6 & 99.13 \\
\hline $02 \cdot 27 \cdot 92$ & $3.6961^{\circ}$ & $\cdots$ & 7.4 & $\cdots$ \\
\hline $02 \cdot 27-92$ & $\cdots$ & 0.0186 & 7.5 & 99.35 \\
\hline $02 \cdot 28-92$ & 2.8621 & $\cdots$ & 7.2 & $\cdots$ \\
\hline $02 \cdot 28-92$ & $\cdots$ & 0.0164 & 6.6 & 99.43 \\
\hline
\end{tabular}

- Multicyclone sampling

- Sampling error

- Ammonia injection on

${ }^{d}$ Damaged bag

- Ammonia injection off

continued... 
TABLE 3 (continued)

\begin{tabular}{|c|c|c|c|c|}
\hline Test Date & Inlet, gr/scf & Outlet, gr/scf & $\% \mathrm{H}_{2} \mathrm{O}$ & Efficiency ${ }^{\circ}, \%$ \\
\hline \multicolumn{5}{|c|}{ PTC-IL6-419 } \\
\hline $03-09-92$ & 3.2729 & - & 8.3 & - \\
\hline 03-09-92 & $\ldots$ & 0.0279 & 8.3 & 99.15 \\
\hline $03-09-92$ & ..- & 0.0126 & 8.5 & 99.61 \\
\hline $03-10-92$ & 2.9588 & -- & 7.5 & ... \\
\hline $03-10-92$ & $\ldots$ & 0.0212 & 7.2 & 99.28 \\
\hline $03-10-92$ & $2.8594^{\mathrm{a}}$ & - & 7.0 & $\cdots$ \\
\hline $03-11-92$ & 2.4762 & -- & 9.1 & $\cdots$ \\
\hline 03-11-92 & -- & 0.0006 & 0.0 & 99.98 \\
\hline 03.11 .92 & - & 0.0088 & 7.2 & 99.64 \\
\hline $03-12-92$ & $2.7558^{\mathrm{a}}$ & - & 7.4 & $\ldots$ \\
\hline $03-12.92$ & 2.2041 & - & 6.5 & $\ldots$ \\
\hline $03-12-92^{b}$ & $\ldots$ & $\ldots$ & $\ldots$ & $\cdots$ \\
\hline $03-13-92$ & 2.9318 & - & 8.0 & $\ldots$ \\
\hline 03-13-92 & $\ldots$ & 0.0190 & 7.3 & 99.35 \\
\hline $03-13-92$ & -.. & 0.0157 & 7.0 & 99.47 \\
\hline \multicolumn{5}{|c|}{ PTC-BV-423 } \\
\hline $04-20-92$ & 2.2618 & - & 8.7 & $\cdots$ \\
\hline 04-20-92 &.-- & 0.0708 & 6.4 & $96.87^{d}$ \\
\hline 04-20-92 & $\ldots$ & 0.0808 & 6.9 & $96.48^{d}$ \\
\hline 04-20-92 & 2.2943 & - & 7.9 & $\ldots$ \\
\hline 04-21-92 & 2.6303 & - & 7.0 & $\ldots$ \\
\hline 04-21-92 & $\cdots$ & 0.0169 & 6.0 & 99.36 \\
\hline 04-21-92 & $2.3934^{\mathrm{a}}$ & -. & 6.0 & -. \\
\hline 04-22-92 & 2.7201 & - & 7.2 & -- \\
\hline $04-22-92$ & -- & 0.0096 & 5.7 & 99.65 \\
\hline $04-22-92$ & 2.9149 & - & 6.6 & - \\
\hline 04-22-92 & - & 0.0098 & 5.9 & 99.66 \\
\hline 04-23-92 & 2.0867 & -. & 6.9 & $\cdots$ \\
\hline $04-23-92$ & $\ldots$ & 0.0137 & 5.7 & 99.35 \\
\hline $04-23-92$ & $\ldots$ & 0.0188 & 5.7 & 99.43 \\
\hline $04-24-92$ & 2.4166 & -- & 6.2 & $\ldots$ \\
\hline $04-24-92$ & $\cdots$ & 0.0096 & 5.8 & 99.60 \\
\hline $04-24-92$ & $\cdots$ & 0.0140 & 5.9 & 99.42 \\
\hline
\end{tabular}

- Multicyclone sampling

- Sampling error

' Ammonia injection on

¿ Damaged bag

- Ammonia injection off 
TABLE 3 (continued)

\begin{tabular}{|c|c|c|c|c|}
\hline Test Date & Inlet, gr/scf & Outlet, gr/scf & $\% \mathrm{H}_{2} \mathrm{O}$ & Efficiency ${ }^{c}, \%$ \\
\hline \multicolumn{5}{|c|}{ PTC-BT.424 } \\
\hline $04-27-92$ & 1.4438 & - & 11.2 & - \\
\hline $04-27-92$ & - & 0.0019 & 9.8 & 99.87 \\
\hline $04-27-92$ & 1.4580 & - & 13.0 & - \\
\hline $04-28-92$ & 1.4172 & - & 9.0 & - \\
\hline $04-28-92$ & - & 0.0013 & 10.4 & 99.91 \\
\hline $04-28-92$ & - & 0.0017 & 9.9 & 99.88 \\
\hline $04-28-92$ & $1.3724^{\mathrm{a}}$ & - & 10.0 & - \\
\hline 04-29-92 & 1.6121 & - & 6.9 & - \\
\hline 04-29-92 & - & 0.0014 & 11.1 & 99.91 \\
\hline $04-29-92$ & 1.6095 & .. & 12.8 & - \\
\hline $04-29-92$ & - & 0.0031 & 11.1 & 99.81 \\
\hline $04-30-92$ & 1.6565 & - & 10.4 & - \\
\hline 04-30-92 & - & 0.0020 & 11.4 & 99.88 \\
\hline 04-30-92 & $1.5001^{\mathrm{a}}$ & - & 11.0 & - \\
\hline 04-30-92 & - & 0.0022 & 11.2 & 99.86 \\
\hline 05-01-92 & 1.2015 & - & 10.8 & - \\
\hline $05-01-92$ & - & 0.0012 & 10.8 & 99.90 \\
\hline \multicolumn{5}{|c|}{ PTC-BU-425 } \\
\hline $05-04-92$ & 3.1896 & - & 13.3 & - \\
\hline $05-04-92$ & 3.2460 & - & 13.4 & - \\
\hline $05-04-92$ & - & 0.0016 & 11.9 & 99.95 \\
\hline 05-05-92 & 2.8109 & - & 10.2 & - \\
\hline $05-05-92$ & -- & 0.0024 & 12.3 & 99.93 \\
\hline 05-05-92 & - & 0.0027 & 12.6 & 99.90 \\
\hline 05-05-92 & $3.0938^{a}$ & -- & 10.9 & - \\
\hline 05-06-92 & 2.9817 & - & 13.0 & - \\
\hline 05-06-92 & - & 0.0022 & 12.5 & 99.93 \\
\hline $05-06-92$ & 2.6618 & - & 12.0 & - \\
\hline 05-06-92 & $\cdots$ & 0.0020 & 13.1 & 99.93 \\
\hline 05-07.92 & 2.9079 & $\cdots$ & 11.3 & $\ldots$ \\
\hline $05-07.92$ & - & 0.0022 & 12.7 & 99.92 \\
\hline 05-07-92 & $2.3009^{\circ}$ & $\ldots$ & 12.2 & -- \\
\hline 05-08-92 & 2.8196 & -. & 13.5 & -. \\
\hline
\end{tabular}

- Multicyclone sampling

b Sampling error

- Ammonia injection on

¿ Damaged bag

- Ammonia injection off 
TABLE 3 (continued)

\begin{tabular}{|c|c|c|c|c|}
\hline Test Date & Inlet, gr/scf & Outlet, gr/scf & $\% \mathrm{H}_{2} \mathrm{O}$ & Efficiency ${ }^{\circ}, \%$ \\
\hline \multicolumn{5}{|c|}{ PTC-BU-425 (continued) } \\
\hline $05-08-92$ & - & 0.0040 & 12.7 & 99.86 \\
\hline \multicolumn{5}{|c|}{ PTC-IL 6-426 } \\
\hline $05-11-92$ & 3.9122 & -- & 9.6 & - \\
\hline 05.11 .92 & - & 0.0273 & 8.2 & 99.30 \\
\hline $05-12-92$ & 3.0983 & - & 7.9 & -- \\
\hline $05 \cdot 12-92$ & -- & 0.0141 & 7.6 & 99.55 \\
\hline $05-12-92$ & - & 0.0079 & 7.6 & 99.75 \\
\hline 05-13-92 & 4.0802 & - & 7.4 & -- \\
\hline 05-13-92 & $\cdots$ & 0.0022 & 6.8 & 99.95 \\
\hline 05-13-92 & -- & 0.0026 & 6.5 & 99.94 \\
\hline 05-14-92 & 4.1596 & - & 7.4 & $\ldots$ \\
\hline 05-14-92 & - & 0.0295 & 7.6 & 99.29 \\
\hline 05-15-92 & 3.7020 & -. & 6.9 & -. \\
\hline $05-15-92$ & - & 0.0148 & 6.7 & 99.60 \\
\hline \multicolumn{5}{|c|}{ PTC-IL6-427 } \\
\hline 05-19-92 & 2.5287 & -. & 9.0 & - \\
\hline 05.19.92 & $\cdots$ & 0.0161 & 8.6 & 99.37 \\
\hline 05-19-92 & - & 0.0110 & 9.1 & 99.57 \\
\hline $05.21-92$ & 2.6484 & $\ldots$ & 9.3 & -- \\
\hline $05-21.92$ & - & 0.0069 & 9.1 & 99.74 \\
\hline 05.21 .92 & - & 0.0127 & 9.1 & 99.52 \\
\hline \multicolumn{5}{|c|}{ PTC-IL6.428 } \\
\hline 06.08-92 & 2.7129 & - & 10.8 & - \\
\hline 06-08-92 & - & 0.0142 & 10.1 & 99.48 \\
\hline 06-08-92 & - & 0.0178 & 10.1 & 99.34 \\
\hline 06-09-92 & $2.7043^{a}$ & - & 9.7 & -- \\
\hline 06-09-92 & - & 0.0184 & 10.0 & 99.32 \\
\hline 06-09-92 & - & 0.0170 & 9.1 & 99.37 \\
\hline 06-10-92 & 2.7906 & $\ldots$ & 10.5 & $\cdots$ \\
\hline $06-10-9 ?$ & -- & 0.0111 & 10.8 & 99.60 \\
\hline $06-10-92$ & $\cdots$ & 0.0141 & 9.4 & 99.49 \\
\hline $06.11-92$ & $2.6813^{\circ}$ & -- & 9.8 & $\ldots$ \\
\hline
\end{tabular}

-Multicyclone sampling

- Sampling error

- Ammonia injection on

- Damaged bag

- Ammonia injection off 
TABLE 3 (continued)

\begin{tabular}{|c|c|c|c|c|}
\hline Test Date & Inlet, gr/scf & Outlet, gr/scf & $\% \mathrm{H}_{2} \mathrm{O}$ & Efficiency ${ }^{\circ}, \%$ \\
\hline \multicolumn{5}{|c|}{ PTC.IL6-428 (continued) } \\
\hline $06-11-92$ & - & 0.0107 & 10.0 & 99.60 \\
\hline 06-11-92 & - & 0.0105 & 11.6 & 99.61 \\
\hline $06 \cdot 12-92$ & 2.9665 & -. & 10.2 & - \\
\hline $06-12-92$ & - & 0.0160 & 9.4 & 99.46 \\
\hline $06-12-92$ & -. & 0.0151 & 9.0 & 99.49 \\
\hline \multicolumn{5}{|c|}{ PTC-BV-429 } \\
\hline $06-28-92$ & 1.8705 & $\ldots$ & 8.5 & - \\
\hline 06-28-92 & - & 0.0006 & 7.9 & $99.97^{\circ}$ \\
\hline $06-28-92$ & - & 0.0114 & 7.4 & 99.39 \\
\hline $06-29-92$ & $2.0149^{\circ}$ & -. & 7.3 & - \\
\hline $06-29-92$ & - & 0.0008 & 6.0 & $99.96^{\circ}$ \\
\hline $06 \cdot 29-92$ & - & 0.0066 & 6.4 & 99.67 \\
\hline $06-30-92$ & 2.0726 & -. & 6.2 & - \\
\hline $06 \cdot 30-92$ & - & 0.0002 & 6.5 & $99.99^{\circ}$ \\
\hline $06-30-92$ & - & 0.0119 & 6.5 & 99.43 \\
\hline $07.01-92$ & $1.9431^{\circ}$ & .. & 7.0 & - \\
\hline $07-01-92$ & - & 0.0014 & 6.7 & $99.93^{\circ}$ \\
\hline 07.01 .92 & - & 0.0124 & 6.7 & 99.36 \\
\hline $07-02-92$ & 1.7396 & -. & 7.1 & - \\
\hline $07-02-92$ & - & 0.0057 & 6.9 & 99.68 \\
\hline $07 \cdot 02-92$ & - & 0.0108 & 6.8 & 99.38 \\
\hline \multicolumn{5}{|c|}{ PTC-BT-430 } \\
\hline $07.06-92$ & 1.8478 & ..- & 11.8 & -. \\
\hline $07-06-92$ & $\ldots$ & 0.0003 & 11.0 & $99.98^{\circ}$ \\
\hline $07-06-92$ & - & 0.0015 & 11.3 & 99.92 \\
\hline 07-07-92 & 1.7790 & $\ldots$ & 11.3 & - \\
\hline $07.07-92$ & -- & 0.0021 & 11.5 & $99.89^{\circ}$ \\
\hline $07-07-92$ & - & 0.0016 & 11.1 & 99.91 \\
\hline $07.08-92$ & $1.8467^{a}$ & $\ldots$ & 11.3 & - \\
\hline $07.08-92$ & - & 0.0004 & 11.3 & $99.98^{\circ}$ \\
\hline $07 \cdot 08-92$ & - & 0.0007 & 11.0 & 99.96 \\
\hline $07-09-92$ & $1.8102^{a}$ & -. & 11.2 & - \\
\hline 07-09-92 & - & 0.0009 & 11.1 & $99.95^{\circ}$ \\
\hline
\end{tabular}

a Multicyclone sampling

b Sampling error

- Ammonia injection on

d Damaged bag

- Ammonia injection off 
TABLE 3 (continued)

\begin{tabular}{|c|c|c|c|c|}
\hline Test Date & Inlet, gr/scf & Outlet, gr/scf & $\% \mathrm{H}_{2} \mathrm{O}$ & Efficiency $^{c}, \%$ \\
\hline \multicolumn{5}{|c|}{ PTC-BT-430 (continued) } \\
\hline $07-09-92$ & ... & 0.0007 & 11.3 & 99.96 \\
\hline $07 \cdot 10-92$ & 1.7941 & $\ldots$ & 10.2 & - \\
\hline $07-10-92$ & $\ldots$ & 0.0008 & 10.4 & $99.96^{\circ}$ \\
\hline $07-10-92$ & $\cdots$ & 0.0004 & 10.6 & 99.98 \\
\hline \multicolumn{5}{|c|}{ PTC-RO-431 } \\
\hline $07-20-92$ & 0.0182 & -. & 11.0 & $\ldots$ \\
\hline 07-20-92 & ..- & 0.0003 & 10.4 & $99.52^{\circ}$ \\
\hline $07-20-92$ & $\ldots$ & 0.0019 & 10.2 & 89.59 \\
\hline $07-21-92$ & $0.0216^{\mathrm{a}}$ & $\cdots$ & 9.4 & $\therefore$ \\
\hline $07-21-92$ & -- & 0.0002 & 9.6 & $98.85^{\circ}$ \\
\hline $07-21-92$ & -. & 0.0003 & 9.4 & $98.36^{\circ}$ \\
\hline 07-21-92 & - & 0.0002 & 9.5 & $99.14^{\circ}$ \\
\hline 07-21-92 & -.. & 0.0091 & 9.5 & 57.78 \\
\hline 07-22-92 & 0.0405 & $\ldots$ & 10.7 & $\ldots$ \\
\hline 07-22-92 & $\ldots$ & 0.0094 & 9.4 & 56.47 \\
\hline 07-22-92 & -. & 0.0029 & 9.6 & 86.44 \\
\hline $07-22-92$ & ... & 0.0002 & 9.7 & $99.51^{\circ}$ \\
\hline $07-22-92$ & $\ldots$ & 0.0109 & 9.9 & 73.18 \\
\hline $07-23-92$ & 0.0040 & - & 9.7 & ... \\
\hline 07-23-92 & $\ldots$ & 0.0099 & 9.8 & 75.64 \\
\hline 07-23-92 & - & 0.0013 & 9.5 & 96.79 \\
\hline 07-23-92 & -. & 0.0002 & 9.8 & $95.80^{\circ}$ \\
\hline 07-23-92 & -- & 0.0159 & 9.5 & 53.37 \\
\hline $07-24-92$ & 0.0277 & ... & 10.3 & $\ldots$ \\
\hline 07-24-92 & $\cdots$ & 0.0167 & 9.9 & 39.70 \\
\hline 07-24-92 & -- & 0.0103 & 9.8 & 62.94 \\
\hline $07-24-92$ & $\ldots$ & 0.0002 & 9.1 & $99.17^{\circ}$ \\
\hline $07-24-92$ & -. & 0.0145 & 9.9 & 47.59 \\
\hline $07-24-92$ & -.. & 0.0057 & 10.1 & 75.07 \\
\hline $07-24-92$ & $\cdots$ & 0.0223 & 10.0 & 19.51 \\
\hline \multicolumn{5}{|c|}{ PTC.BV-432 } \\
\hline $08 \cdot 10-92$ & 2.2154 & -. & 7.5 & - \\
\hline 08-10-92 & $\cdots$ & 0.0051 & 6.8 & 99.77 \\
\hline
\end{tabular}

- Multicyclone sampling

b Sampling error

- Ammonia injection on

d Damaged bag

- Ammonia injection off

continued... 
TABLE 3 (continued)

\begin{tabular}{|c|c|c|c|c|}
\hline Test Date & Inlet, gr/scf & Outlet, gr/scf & $6 \mathrm{H}_{2} \mathrm{O}$ & Efficiency ${ }^{c}, \%$ \\
\hline \multicolumn{5}{|c|}{ PTC-BV-432 (continued) } \\
\hline $08-10-92$ & - & 0.0078 & 6.6 & 99.65 \\
\hline $08-11.92$ & $2.1354^{\mathrm{a}}$ & - & 8.2 & $\ldots$ \\
\hline 08-11-92 & -- & 0.0025 & 7.0 & 99.89 \\
\hline $08-11.92$ & - & 0.0127 & 7.0 & 99.41 \\
\hline 08-12-92 & -- & 0.0204 & 6.5 & 99.04 \\
\hline $08-12.92$ & -. & 0.0249 & 6.3 & 98.83 \\
\hline $08 \cdot 13 \cdot 92$ & $1.7734^{\mathrm{a}}$ & - & 7.7 & $\ldots$ \\
\hline 08-13-92 & -. & 0.0253 & 6.2 & 98.82 \\
\hline $08 \cdot 13-92$ & $\ldots$ & 0.0830 & 6.1 & 96.13 \\
\hline $08 \cdot 14-92$ & 2.0705 & - & 6.8 & -.. \\
\hline $08-14-92$ & -- & 0.0065 & 6.8 & 99.68 \\
\hline $08-14-92$ & -- & 0.0107 & 6.7 & 99.48 \\
\hline 08-17-92 & 2.0650 & - & 7.4 & -. \\
\hline 08-17-92 & $\cdots$ & 0.0108 & 6.8 & 99.48 \\
\hline 08-17-92 & - & 0.0059 & 6.8 & 99.72 \\
\hline $08-18-92$ & $2.0063^{\mathrm{a}}$ & - & 7.3 & -.- \\
\hline $08-18-92$ & $\cdots$ & 0.0089 & 6.8 & 99.56 \\
\hline $08-18-92$ & $\cdots$ & 0.0124 & 6.8 & 99.38 \\
\hline 08-19-92 & - & 0.0185 & 6.7 & 99.10 \\
\hline 08-19-92 & -- & 0.0555 & 6.7 & 97.31 \\
\hline 08-20-92 & -- & 0.0182 & 7.6 & 99.12 \\
\hline $08 \cdot 20-92$ & 1.7678 & - & $19.5^{\mathrm{b}}$ & $\ldots$ \\
\hline $08-20-92$ & $\ldots$ & 0.0188 & 7.9 & 99.09 \\
\hline 08-21-92 & $2.3792^{a}$ & $\cdots$ & 7.5 & $\cdots$ \\
\hline 08-21-92 & -- & 0.0143 & 6.6 & 99.40 \\
\hline 08-21-92 & - & 0.0182 & 6.4 & 99.24 \\
\hline 08-24-92 & 2.0580 & - & 7.6 & $\ldots$ \\
\hline $08-24-92$ & $\cdots$ & 0.0197 & 9.9 & 99.04 \\
\hline 08-24-92 & -. & 0.0156 & 7.0 & 99.24 \\
\hline 08-25-92 & $1.8968^{a}$ & -. & 6.6 & $\cdots$ \\
\hline 08-25-92 & $\cdots$ & 0.0475 & 6.6 & 97.69 \\
\hline $08-25-92$ & $\cdots$ & 0.0110 & 6.7 & 99.46 \\
\hline 08-26-92 & $\ldots$ & 0.0212 & 6.9 & 98.97 \\
\hline 08-26-92 & -.. & 0.0328 & 6.4 & 98.40 \\
\hline
\end{tabular}

a Multicyclone sampling

b Sampling error

- Ammonia injection on

${ }^{d}$ Damaged bag

- Ammonia injection off

continued... 
TABLE 3 (continued)

\begin{tabular}{|c|c|c|c|c|}
\hline Test Date & Inlet, $\mathrm{gr} / \mathrm{scf}$ & Outlet, gr/scf & $\% \mathrm{H}_{2} \mathrm{O}$ & Efficiency $^{c}, \%$ \\
\hline \multicolumn{5}{|c|}{ PTC-BV-432 (continued) } \\
\hline 08-27-92 & $1.8580^{a}$ & -- & 6.6 & - \\
\hline 08-27-92 & -. & 0.0208 & 7.4 & 99.01 \\
\hline 08-27-92 & -. & 0.0199 & 6.9 & 99.00 \\
\hline 08-28-92 & 2.2632 & $\ldots$ & 7.8 & .- \\
\hline 08-28-92 & -. & 0.0134 & 4.7 & 99.41 \\
\hline 08-28-92 & $\ldots$ & 0.0138 & 7.2 & 99.39 \\
\hline 09-30-92 & $\ldots$ & 0.0020 & 6.5 & 99.92 \\
\hline 09-30-92 & 2.4905 & -- & 7.1 & -- \\
\hline 09-30-92 & -- & 0.0143 & 6.5 & 99.42 \\
\hline 09-30-92 & - & 0.0066 & 6.8 & 99.69 \\
\hline 09-30-92 & 2.1145 & -- & 6.5 & $\ldots$ \\
\hline 09-30-92 & 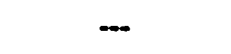 & 0.0071 & 6.6 & 99.66 \\
\hline 10-01-92 & - & 0.0104 & 6.3 & 99.44 \\
\hline 10-01-92 & 1.8431 & $\ldots$ & 7.3 & $\ldots$ \\
\hline 10-01-92 & - & 0.0166 & 6.6 & 99.10 \\
\hline 10-01-92 & - & 0.0153 & 6.5 & 99.35 \\
\hline 10-01-92 & 2.3349 & -. & 6.7 & $\cdots$ \\
\hline 10-01-92 & - & 0.0117 & 6.5 & 98.50 \\
\hline 10-01-92 & - & 0.0137 & 6.5 & 99.42 \\
\hline 10-01-92 & 2.3574 & -. & 7.0 & $\ldots$ \\
\hline
\end{tabular}

- Multicyclone sampling

' Sampling error

- Ammonia injection on

¿ Damaged bag

- Ammonia injection off

At an air-to-cloth ratio of $2 \mathrm{ft} / \mathrm{min}$, the pulse-jet bags were cleaned at ten minute intervals to maintain a baghouse differential pressure of less than 3 inches W.C. After roughly ten hours, the reservoir pressure was increased from 12 to $24 \mathrm{psig}$ in order to continue on-line cleaning. At air-to-cloth ratios of 3 and $4 \mathrm{ft} / \mathrm{min}$ it was necessary to clean the bags off-line every 12 hours in addition to cleaning on-line at ten minute intervals. The bags were cleaned off-line when the pressure drop approached 4 inches W.C. At the start of the 4-ft/min air-to-cloth ratio test period, the reservoir pressure was increased to $48 \mathrm{psig}$ and then dropped to $35 \mathrm{psig}$. At an air-to-cloth ratio of $3 \mathrm{ft} / \mathrm{min}$ the reservoir pressure was decreased to $24 \mathrm{psig}$, but the baghouse Fis essure drop increased to 4.5 inches W.C. in roughly 4 hours, therefore, the reservoir pressure was again raised to $35 \mathrm{psig}$. At an air-to-cloth ratio of $6 \mathrm{ft} / \mathrm{min}$, the bags were cleaned on-line at one-minute intervals with 0.46 -second pulse durations, and off-line every hour to maintain a pressure drop of less than 7 inches W.C. The reservoir pressure was maintained at 35 psig. Figure 17 plots the baghouse differential pressure as a function of time, based on off-line cleaning data. 
TABLE 4

Multicyclone Data from PTC-BV-429

\begin{tabular}{|c|c|c|c|c|c|c|}
\hline $\begin{array}{l}\text { PTC-BV-429 } \\
06-29-92\end{array}$ & CY1 & CY2 & $\mathrm{CY} 3$ & CY4 & CY5 & $\begin{array}{l}\text { Backup } \\
\text { Filter }\end{array}$ \\
\hline $\mathrm{d}_{50}, \mu \mathrm{m}$ & 10.20 & 7.06 & 3.87 & 2.60 & 1.08 & -- \\
\hline Mass Collected, $\mathrm{g}$ & 1.2821 & 0.0987 & 0.0527 & 0.0270 & 0.0201 & 0.0303 \\
\hline$\%$ Total Mass & 84.86 & 6.53 & 3.49 & 1.79 & 1.33 & 2.01 \\
\hline $\begin{array}{l}\text { Cumulative } \% \text { Mass } \\
\text { less than } d_{50}\end{array}$ & 15.14 & 8.60 & 5.12 & 3.33 & 2.01 & $\cdots$ \\
\hline \multicolumn{7}{|c|}{$\begin{array}{l}\text { Total Mass Collected }=1.5107 \mathrm{~g}, \text { Dust Loading }=2.0149 \mathrm{gr} / \mathrm{scf} \\
\% \text { Isokinetic }=95.40\end{array}$} \\
\hline $\begin{array}{l}\text { PTC-BV-429 } \\
07.01 .92\end{array}$ & CY1 & CY2 & CY3 & CY4 & CY5 & $\begin{array}{l}\text { Backup } \\
\text { Filter }\end{array}$ \\
\hline$d_{30}, \mu \mathrm{m}$ & 10.16 & 7.04 & 3.86 & 2.59 & 1.07 & -. \\
\hline Mass Collected, $\mathrm{g}$ & 1.2497 & 0.0803 & 0.0587 & 0.0229 & 0.0168 & 0.0307 \\
\hline$\%$ Total Mass & 85.65 & 5.50 & 4.02 & 1.57 & 1.15 & 2.11 \\
\hline $\begin{array}{l}\text { Cumulative \% Mass } \\
\text { less than } d_{50}\end{array}$ & 14.35 & 8.85 & 4.83 & 3.25 & 2.11 & -. \\
\hline \multicolumn{7}{|c|}{$\begin{array}{l}\text { Total Mass Collected }=1.4591 \mathrm{~g}, \text { Dusting L Loading }=1.9431 \mathrm{gr} / \mathrm{scf} \\
\% \text { Isokinetic }=98.30\end{array}$} \\
\hline
\end{tabular}

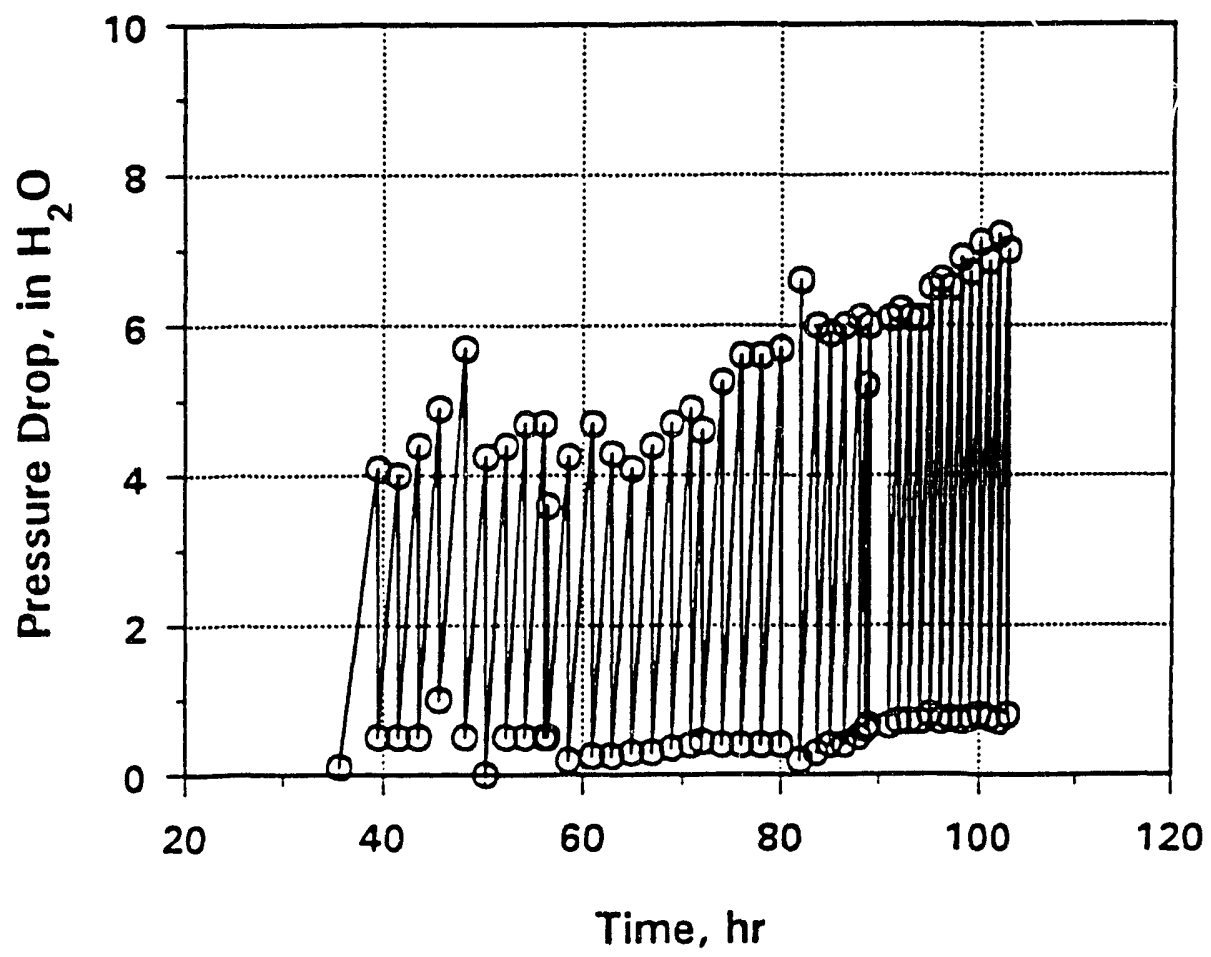

Figure 16. Baghouse differential pressure as a function of time, PTC-BV.429. 


\section{TABLE 5}

Multicyclone Data from PTC-BT-430

\begin{tabular}{|c|c|c|c|c|c|c|}
\hline $07-08-92$ & CY1 & CY2 & CY3 & CY4 & CY5 & $\begin{array}{l}\text { Backup } \\
\text { Filter }\end{array}$ \\
\hline $\mathrm{d}_{30}, \mu \mathrm{m}$ & 9.88 & 6.74 & 3.67 & 2.48 & 1.03 & - \\
\hline Mass Collected, $\mathrm{g}$ & 1.2157 & 0.0897 & 0.0614 & 0.0294 & 0.0340 & 0.0111 \\
\hline$\%$ Total Mass & 84.36 & 6.22 & 4.26 & 2.04 & 2.36 & 0.77 \\
\hline $\begin{array}{l}\text { Cumulative } \% \\
\text { Mass less than } d_{s 0}\end{array}$ & 15.64 & 9.42 & 5.16 & 3.12 & 0.77 & $\ldots$ \\
\hline \multicolumn{7}{|c|}{$\begin{array}{l}\text { Total Mass Collected }=1.4412 \mathrm{~g}, \text { Dust Loading }=1.8467 \mathrm{gr} / \mathrm{scf} \\
\% \text { Isokinetic }=100.0\end{array}$} \\
\hline 07-09-92 & CY1 & CY2 & CY3 & CY4 & CY5 & $\begin{array}{l}\text { Backup } \\
\text { Filter }\end{array}$ \\
\hline $\mathrm{d}_{50}, \mu \mathrm{m}$ & 9.90 & 6.76 & 3.69 & 2.49 & 1.03 & $\cdots$ \\
\hline Mass Collected, $\mathrm{g}$ & 1.1718 & 0.0746 & 0.0672 & 0.0325 & 0.0261 & 0.0348 \\
\hline$\%$ Total Mass & 83.29 & 5.30 & 4.78 & 2.31 & 1.85 & 2.47 \\
\hline $\begin{array}{l}\text { Cumulative } \% \\
\text { Mass less than } d_{s 0}\end{array}$ & 16.71 & 11.41 & 6.64 & 4.33 & 2.47 & $\ldots$ \\
\hline \multicolumn{7}{|c|}{$\begin{array}{l}\text { Total Mass Collected }=1.4069 \mathrm{~g}, \text { Dust Loading }=1.8102 \mathrm{gr} / \mathrm{scf} \\
\% \text { Isokinetic }=99.60\end{array}$} \\
\hline
\end{tabular}

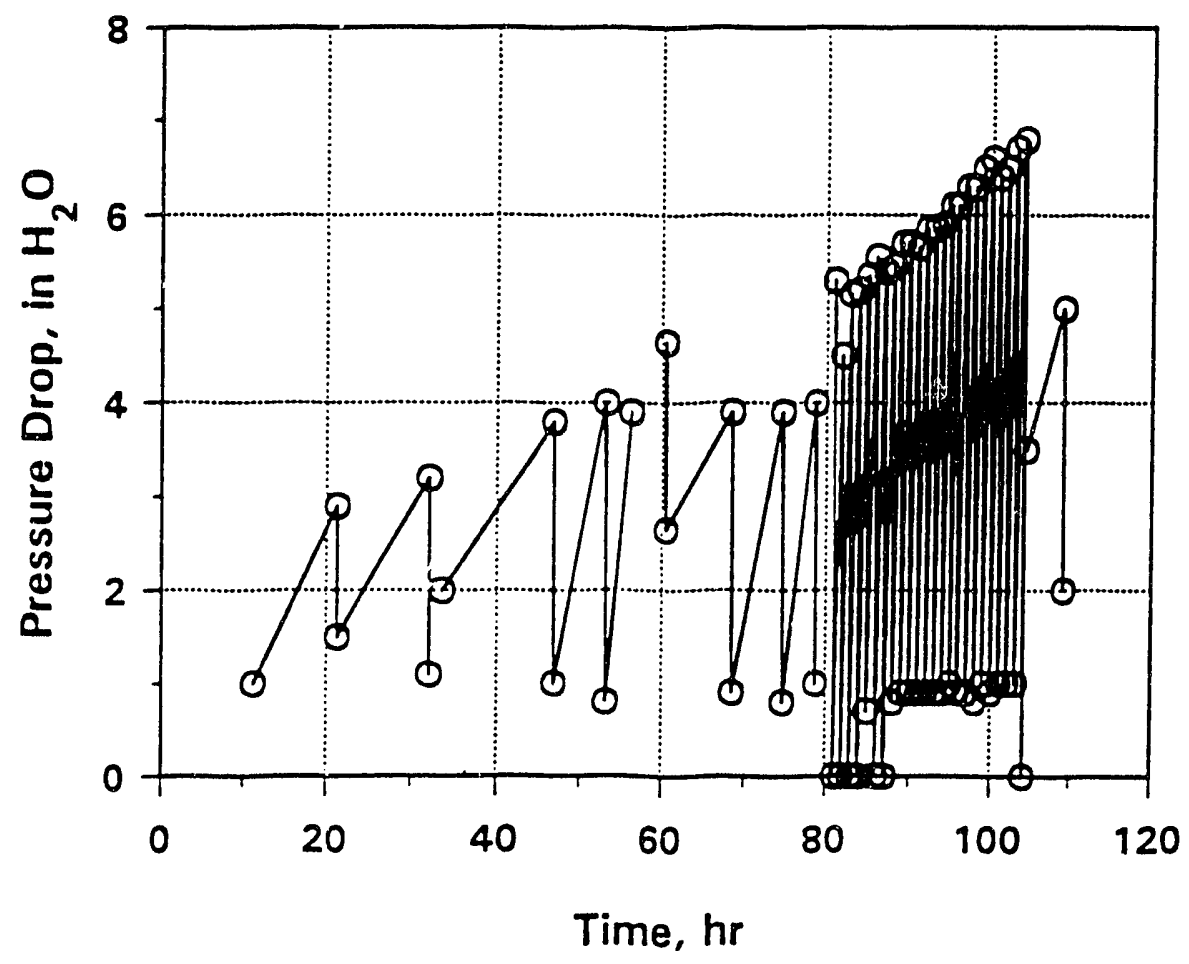

Figure 17. Baghouse differential pressure as a function of time, PTC-BT-430. 


\subsubsection{PTC-RO- 431}

For test PTC-RO-431 respirable mass data was collected at air-to-cloth ratios of 2,3 , 4 , and $6 \mathrm{ft} / \mathrm{min}$. At an air-to-cloth ratio of $2 \mathrm{ft} / \mathrm{min}$ the respirable mass ranged from roughly $1 \times 10^{3}$ to $0.08 \mathrm{mg} / \mathrm{m}^{3}$. At an air-to-cloth ratio of $3 \mathrm{ft} / \mathrm{min}$ the respirable mass ranged from roughly $4 \times 10^{3}$ to $0.07 \mathrm{mg} / \mathrm{m}^{3}$. At an air-to-cloth ratio of $4 \mathrm{ft} / \mathrm{min}$ the respirable mass ranged from roughly $8 \times 10^{-4}$ to $5 \times 10^{3} \mathrm{mg} / \mathrm{m}^{3}$. At an air-to-cloth ratio of $6 \mathrm{ft} / \mathrm{min}$ the respirable mass ranged from roughly $5 \times 10^{-1}$ to $0.02 \mathrm{mg} / \mathrm{m}^{3}$. Table 3 summarizes EPA Method 5 particulate-sampling data for PTC-RO-431.

Particulate collection efficiency during the 100-hour test ranged from $95.8 \%$ to $99.5 \%$ with the ammonia injection turned off. The low collection efficiencies are due to very low inlet dust loadings ( 0.02 to $0.04 \mathrm{gr} / \mathrm{sct})$. The bags were precoated with dolomite to form an initial dust cake to prevent blinding of the bags. From the ash samples collected, it appears some of the dolomite was passing through the bags and adding to the outlet dust loading, thereby decreasing the particulate collection efficiency. With the ammonia injection off, the outlet dust loading ranged from 0.0002 to $0.0003 \mathrm{gr} / \mathrm{scf}$. With ammonia injection on, the particulate collection efficiency ranged from $19.5 \%$ to $96.8 \%$. Again, the formation of sulfates in the sample train increased the measured outlet loading, which reduced the particulate collection efficiency. With tha ammonia injection on, the outlet dust loading ranged from 0.001 to $0.022 \mathrm{gr} / \mathrm{scf}$.

At all air-to-cloth ratios the baghouse differential pressure was maintained at less than 3 inches W.C. The bags were only cleaned when the ammonia/NO molar ratio or the air-to-cloth ratio was changed.

\subsubsection{PTC.BV.432}

As previously mentioned, approximately 114 hours into the 500-hour run problems with baghouse differential pressure control were encountered, and the pulse-jet bags were changed. When the first set of bags were removed, inspection of the baghouse revealed that the clean-side of the tube sheet had a significant dust layer and that one of the seven bags had not been cleaning properly. There was no obvious explanation for the dust layer on the tube sheet. Possible causes included direct or indirest penetration of fly ash through the fabric, leakage around the tube sheet, or leakage through the plugs installed in the tube sheet at locations where bags were not installed. Since the pulse-jet bags installed for the 500-hour test were made from woven fabric, direct and indirect fly ash penetration was a possibility. However, inspection of the clean-side of the fabric did not reveal the presence of a residual ash layer, therefore, the contribution of direct and indirect fly ash penetration through the fabric was not significant.

The fly ash layer on the tube sheet was uniform, and ash tracking around the perimeter of the tube sheet or the snap bands securing the bags to the tube sheet was not evident. Therefore, any tube sheet leakage was minimal. The most likely source of flue gas leakage was the plugs used to seal tube sheet holes in which bags were not installed. Inspection of the five plugged tube sheet holes revealed that two of them may have developed flue gas leaks. 
For test PTC-BV 432 integrated averages of respirable mass were taken each day of sampling. The integrated average values each day are plotted in Figure 18. The respirable mass integrated averages ranged from 0.43 to $9.9 \mathrm{mg} / \mathrm{m}^{3}$. Figure 19 plots the particulate emissions on a $\mathrm{lb} / \mathrm{MMM}$ Btu basis as a function of time for the 500 -hour run and the additional coal-fired test periods. The values above the $0.03 \mathrm{lb} / \mathrm{MM}$ Btu New Source Performance Standard (NSPS) may be due to the flue gas leak across the baghouse tube sheet, as well as the formation of sulfates in the sample train due to high levels of ammonia slip. Ammonia injection was not turned off during any of the particulate sampling periods. Tables 3 and 6 summarize EPA Method 5 and multicyclone particulatesampling data.

Particulate collection efficiency during the first 100 hours of the test averaged $99.1 \%$ and ranged from $96.1 \%$ to $99.9 \%$. This is not consistent with the particulate collection data (99.9 to $>99.9 \%$ ) from PTC-BV.429. The possibility of flue gas leakage previously discussed would explain this result. Particulate-sampling data indicated the inlet mass loading to the filters was $2.05 \mathrm{gr} / \mathrm{scf}$. Particulate collection efficiency during the final 400 hours of the test plus the additional 100 hours run later averaged $99.2 \%$ and ranged from $97.3 \%$ to $99.9 \%$, with an average inlet dust loading of 2.26 griscf. Again, the collection efficiency was lower than expected. Figure 20 plots particulate collection efficiency as a function of time for the 500-hour run and the additional coal-fired test periods. With the exception of a few data points, particulate collection efficiency was greater than 99\%. The four data points below $98.5 \%$ represent sampling periods during time frames when baghouse differential pressure became difficult to control due to plugging of the pulse-air system.

The pulse-jet bags were cleaned as a function of baghouse differential pressure. Initially, the cleaning cycle trigger point was 4 inches W.C. and the pulse-air reservoir pressure was 24 psig. However, during the first day of operation the cleaning cycle trigger point was increased to 6 inches W.C. and the pulse-air reservoir pressure was increased to 35 psig. By the end of the first week, it was necessary to increase the pulseair reservoir pressure to 60 psig to adequately control baghouse differential pressure between 4 and 6 inches W.C. on-line. As was stated earlier, oy the end of the first week, on-line cleaning was not adequate to control baghouse differential pressure due to plugging of pulse-air nozzles. After start-up with the second set of bags, the baghouse cleaning cycle was triggered at 5 inches of W.C. and the pulse-air reservoir pressure was set at 60 psig. Baghouse differential pressure was controlled at between 3 and 5 inches W.C. for over 300 hours with on-line cleaning. However, near the end of the 500-hour run, pressure drop began to rise and on-line cleaning was not adequate, again, due to plugging of pulse-air nozzles. Figure 21 plots the pressure drop as a function of time for the pulse-jet bags.

Inspection of the baghouse after termination of the 500-hour run revealed that two of the seven bags were not cleaning properly at the end of the run. Again, inadequate cleaning was due to plugging of pulse-air nozzles. These nozzles were apparently plugged as a result of flue gas and fine particulate migrating through the nozzle into the pulse-air lines. All but one of the pulse-air nozzles had deposits formed at roughly the same elevation in the pulse-air lines. The point at which the deposits formed corresponds to the point at which the pulse-air line exits the top of the baghouse, resulting in a cooler metal surface and an opportunity for condensation. Continuously purging each pulse-air line with a small amount of air ( $1 \mathrm{sch}$ ) should solve this problem. 


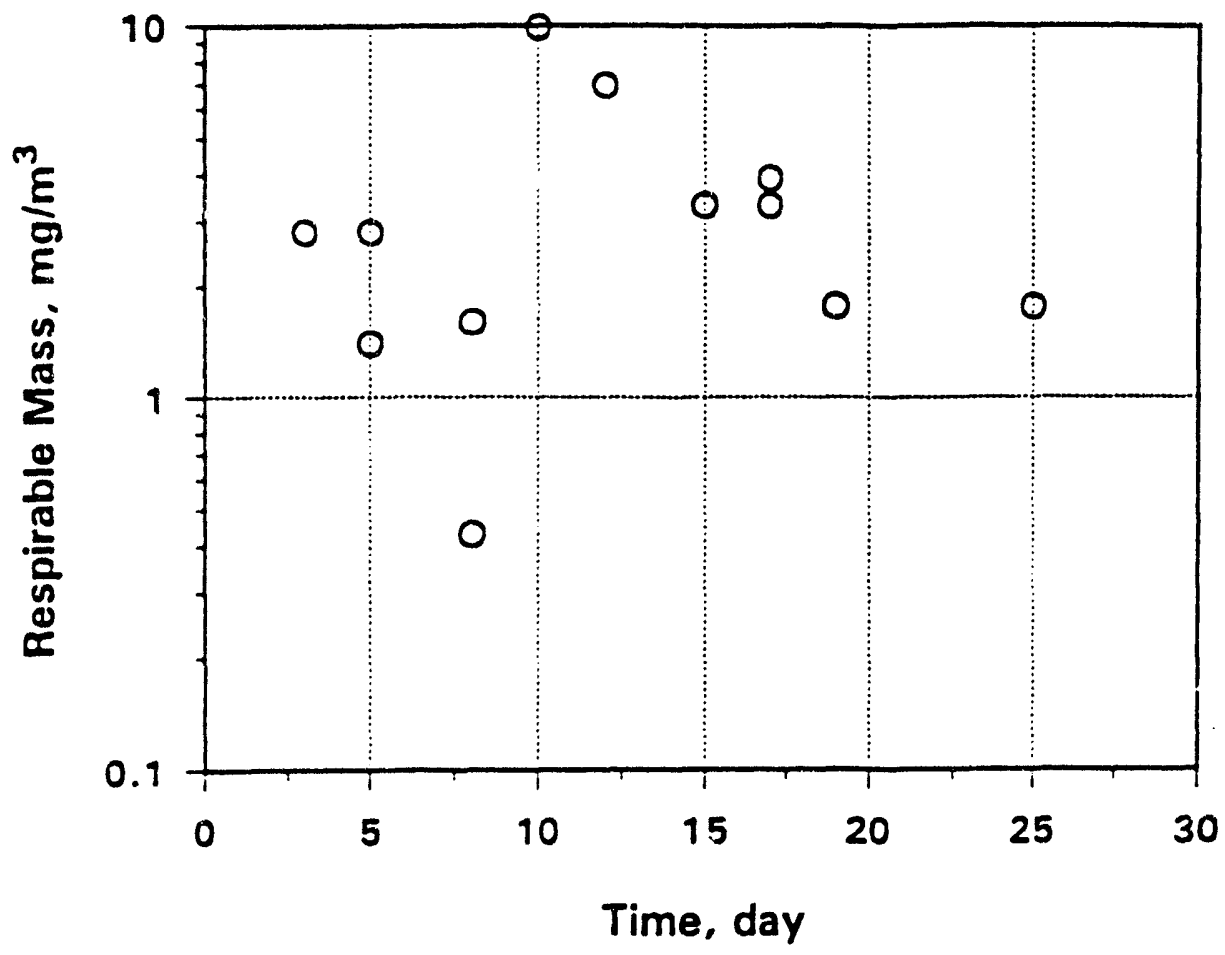

Figure 18. Respirable mass emissions as a function of time. $\bar{F}^{\prime} I^{\prime} C \cdot B^{\top} /-432$.

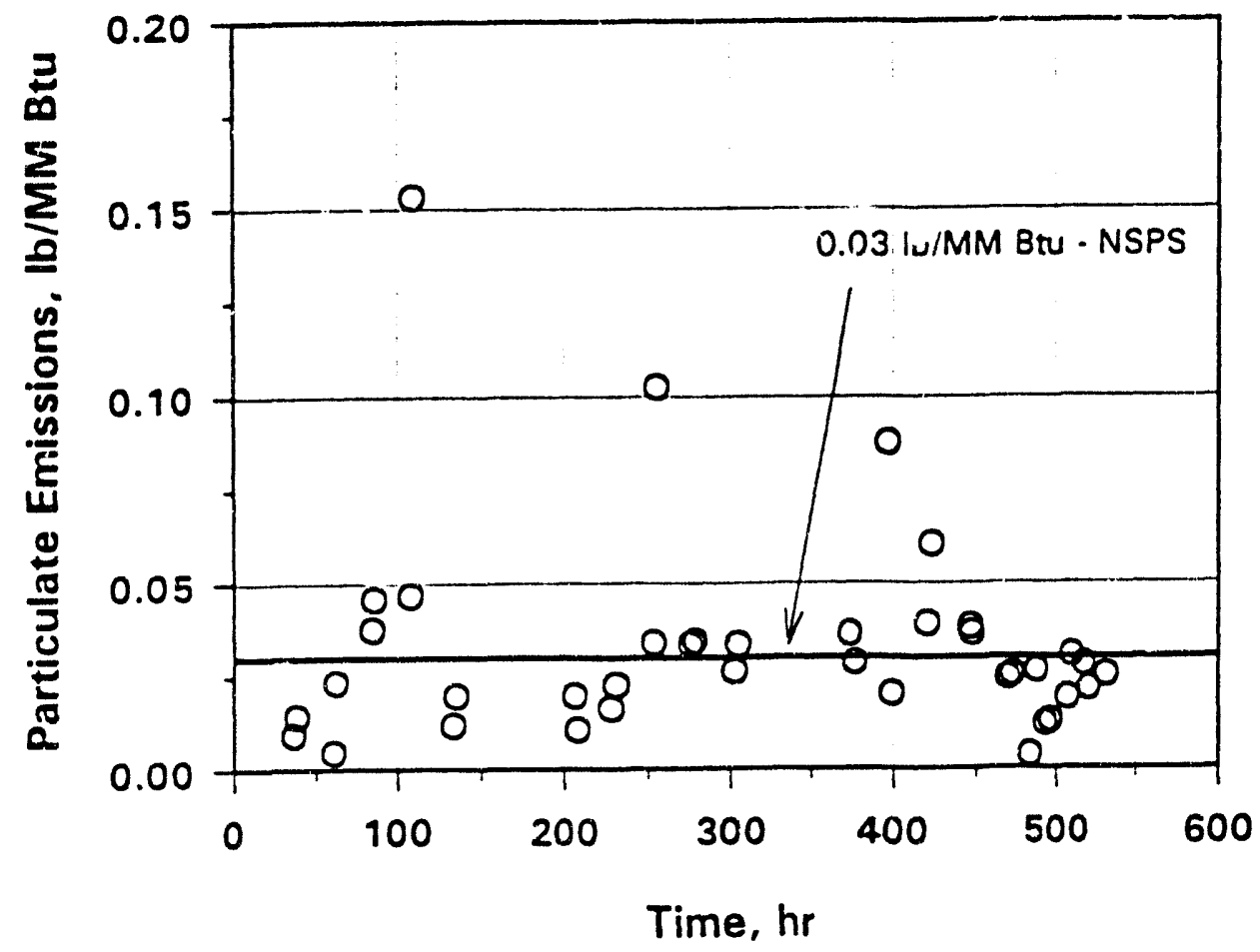

Figure 19. Particulate emissions as a function of time, PTC-BV-432. 
TABLE 6

Multicyclone Data from PTC-BV-432

\begin{tabular}{lcclllc}
\hline 08-11-92 & CY1 & CY2 & CY3 & CY4 & CY5 & $\begin{array}{c}\text { Backup } \\
\text { Filter }\end{array}$ \\
\hline $\mathrm{d}_{\text {so, } \mu \mathrm{m}}$ & 8.32 & 5.19 & 2.75 & 1.90 & 0.79 & - \\
Mass Collected, g & 1.7145 & 0.2656 & 0.0860 & 0.0361 & 0.0232 & 0.0275 \\
\% Total Mass & 79.64 & 12.34 & 4.00 & 1.68 & 1.08 & 1.28 \\
Cumulative \% Mass & 20.36 & 8.02 & 4.03 & 2.35 & 1.28 & $\ldots$
\end{tabular}

less than $d_{50}$

Total Mass Collected $=2.1528 \mathrm{~g}$, Dust Loading $=2.1354 \mathrm{gr} / \mathrm{scf}$

$\%$ Isokinetic $=98.0$

\begin{tabular}{llllllc}
$08-13-92$ & CY1 & CY2 & CY3 & CY4 & CY5 & $\begin{array}{c}\text { Backup } \\
\text { Filter }\end{array}$ \\
\hline $\mathrm{d}_{50}, \mu \mathrm{m}$ & 7.45 & 4.40 & 2.30 & 1.61 & 0.66 & $\ldots$ \\
Mass Collected, g & 1.4290 & 0.1114 & 0.0620 & 0.0220 & 0.0144 & 0.0198 \\
\% Total Mass & 86.15 & 6.72 & 3.74 & 1.32 & 0.87 & 1.20 \\
Cumulative \% Mass & 13.85 & 7.131 & 3.39 & 2.07 & 1.20 & $\ldots$
\end{tabular}

less than $d_{s 0}$

Total Mass Collected $=1.6586 \mathrm{~g}$, Dust Loading $=1.7734 \mathrm{gr} / \mathrm{scf}$

$\%$ Isckinetic $=114.7$

\begin{tabular}{|c|c|c|c|c|c|c|}
\hline $03 . .18 .92$ & CY1 & CY2 & CY3 & CY4 & CY5 & $\begin{array}{c}\text { Backup } \\
\text { Filter }\end{array}$ \\
\hline $\mathrm{d}_{50}, \mu \mathrm{rii}$ & 8.09 & 5.02 & 2.65 & 1.83 & 0.7 & $\cdots$ \\
\hline Mass Ccllected, $\mathrm{g}$ & 2.5148 & 0.3581 & 0.1304 & 0.0513 & 0.0327 & 0.0404 \\
\hline$\%$ Total Mass & 80.40 & 11.45 & 4.17 & 1.64 & 1.05 & 1.29 \\
\hline Cumulative \% Mass & 19.60 & 8.15 & 3.98 & 2.34 & 1.29 & $\ldots$ \\
\hline
\end{tabular}

less than $d_{50}$

Total Mass Collected $=3.1277 \mathrm{~g}$, Dust Loading $=2.0063 \mathrm{gr} / \mathrm{scf}$

$\%$ Isokinetic $=104.1$

\begin{tabular}{llllllc} 
08-21-92 & CY1 & CY2 & CY3 & CY4 & CY5 & $\begin{array}{c}\text { Backup } \\
\text { Filter }\end{array}$ \\
\hline $\mathrm{d}_{\text {30, } \mu \mathrm{m}}$ & 8.14 & 5.03 & 2.66 & 1.84 & 0.76 & $\ldots$ \\
Mass Collected, g & 2.0522 & 0.2358 & 0.1117 & 0.0295 & 0.0127 & 0.0132 \\
\% Total Mass & 83.59 & 9.604 & 4.55 & 1.20 & 0.52 & 0.54 \\
Cumulative \% Mass & 16.41 & 6.80 & 2.25 & 1.05 & 0.54 & $\ldots$ \\
less than $\mathrm{d}_{50}$ & & & & & &
\end{tabular}

less than $\mathrm{d}_{50}$

Total Mass Collected $=2.4550 \mathrm{~g}$, Dust Loading $=2.3792 \mathrm{gr} / \mathrm{scf}$

$\%$ Isokinetic $=103.0$

(continued 
TABLE 6 (continued)

\begin{tabular}{|c|c|c|c|c|c|c|}
\hline 08-28-92 & CY1 & CY2 & CY3 & CY4 & CY5 & $\begin{array}{l}\text { Backup } \\
\text { Filter }\end{array}$ \\
\hline $\mathrm{d}_{s 0, \mu \mathrm{m}}$ & 8.16 & 5.00 & 2.64 & 1.83 & 0.76 & $\ldots$ \\
\hline Mass Collected, $\mathbf{g}$ & 1.6809 & 0.1383 & 0.0707 & 0.0278 & 0.0148 & 0.0239 \\
\hline$\%$ Total Mass & 85.92 & 7.07 & 3.61 & 1.42 & 0.76 & 1.22 \\
\hline $\begin{array}{l}\text { Cumulative } \% \text { Mass } \\
\text { less than } d_{50}\end{array}$ & 14.08 & 7.011 & 3.40 & 1.98 & 1.22 & $\ldots$ \\
\hline \multicolumn{7}{|c|}{$\begin{array}{l}\text { Total Mass Collected }=1.9564 \mathrm{~g}, \text { Dust Loading }=1.8968 \mathrm{gr} / \mathrm{scf} \\
\% \text { Isokinetic }=106.7\end{array}$} \\
\hline $08-27-92$ & CY1 & $\mathrm{CY} 2$ & CY3 & CY4 & CY5 & $\begin{array}{l}\text { Backup } \\
\text { Filter }\end{array}$ \\
\hline $\mathrm{d}_{30}, \mu \mathrm{m}$ & 8.01 & 4.70 & 2.47 & 1.74 & 0.73 & $\ldots$ \\
\hline Mass Collected, g & 2.5364 & 0.1919 & 0.1010 & 0.0392 & 0.0274 & 0.0421 \\
\hline$\%$ Total Mass & 86.33 & 6.53 & 3.44 & 1.33 & 0.93 & 1.43 \\
\hline $\begin{array}{l}\text { Cumulative } \% \text { Mass } \\
\text { less than } d_{50}\end{array}$ & 13.67 & 7.14 & 3.70 & 2.37 & 1.43 & $\cdots$ \\
\hline \multicolumn{7}{|c|}{$\begin{array}{l}\text { Total Mass Collected }=2.9380 \mathrm{~g}, \text { Dust Loading }=1.8280 \mathrm{gr} / \mathrm{scf} \\
\% \text { Isokinetic }=100.5\end{array}$} \\
\hline
\end{tabular}

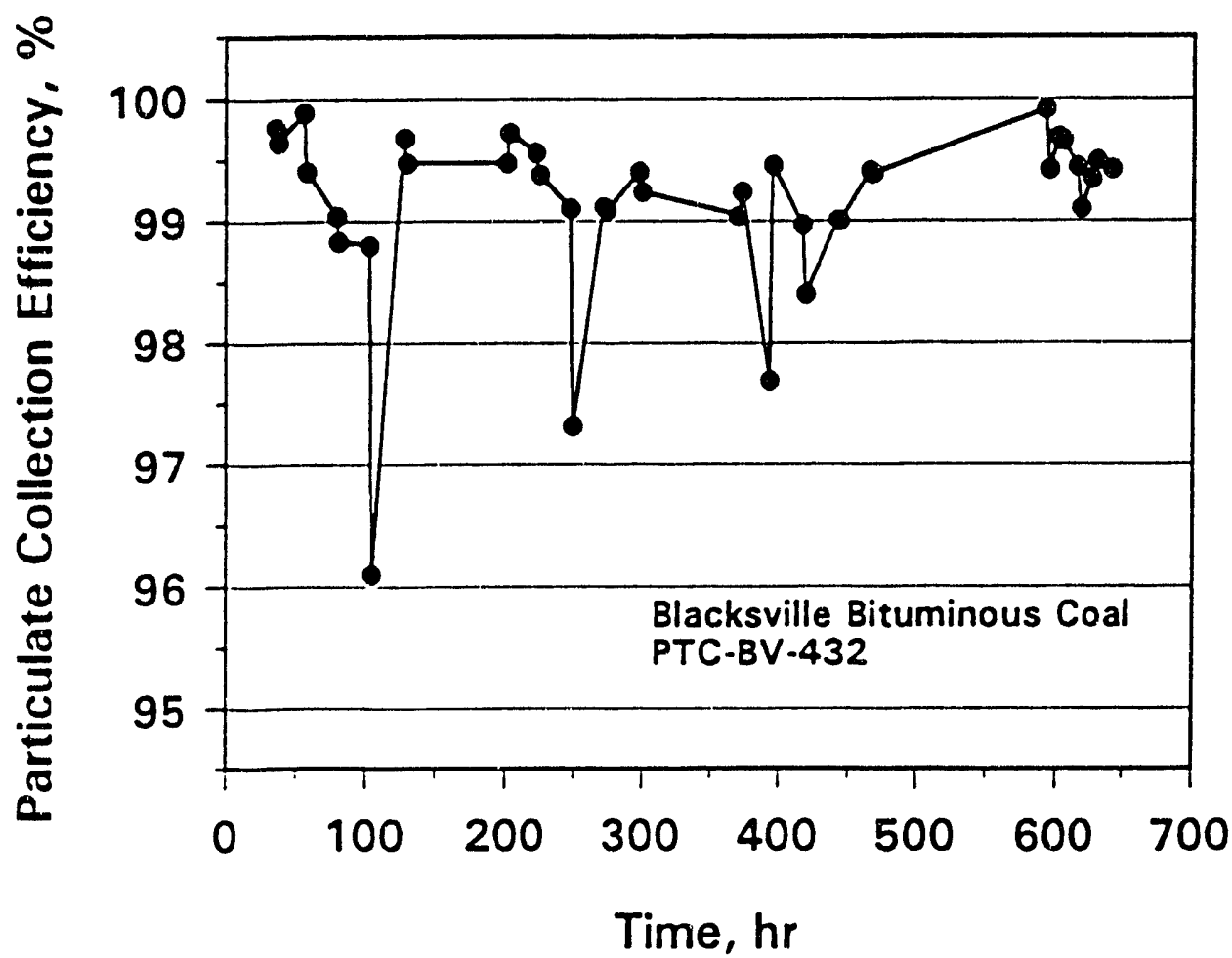

Figure 20. Particulate collection efficiency as a function of time, PTC-BV-432. 


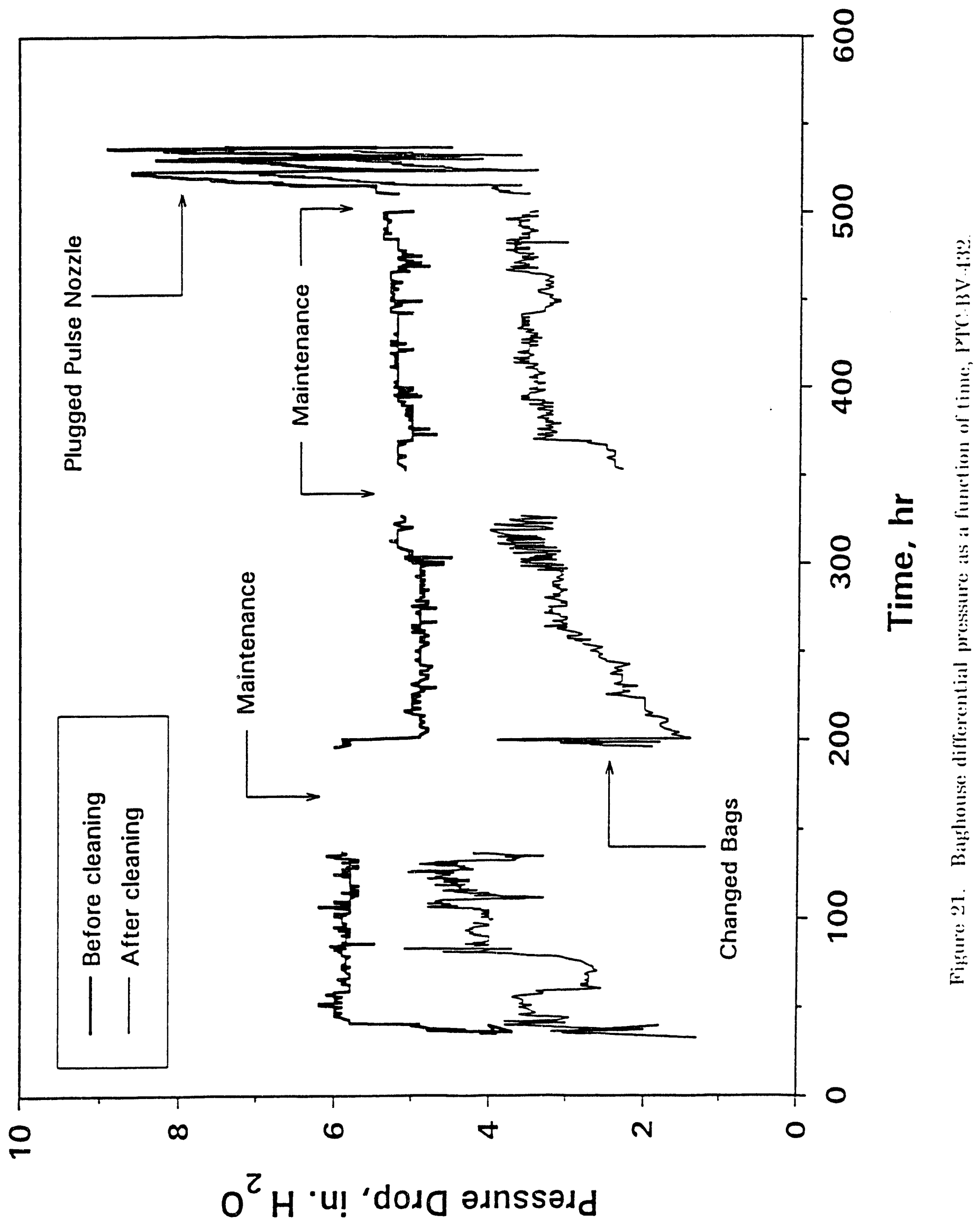




\subsubsection{Summarv of Pulse-Jet Baghouse Test Results}

During this reporting period, tests were performed to determine the effect of fuel type, air-to-cloth ratio, temperature, ammonia/ $\mathrm{NO}_{x}$ molar ratio, and fabric type on $\mathrm{NO}_{x}$ reduction and particulate removal efficiency.

It appears that fuel type has little, if any, effect on $\mathrm{NO}_{\mathbf{z}}$ reduction based on the three 100-hour tests completed. Also, the effect of air-to-cloth ratio when using the 22-ounce DE992 fabric was less significant than what was observed when using the 14-ounce DE484 fabric. As air-to-cloth ratio was increased from 2 to $6 \mathrm{ft} / \mathrm{min}$ during the pulse-jet tests, $\mathrm{NO}_{\mathrm{x}}$ reduction typically changed less than $5 \%$, but ammonia slip increased by factors of 2 to 4 . Based on these results, an air-to-cloth ratio of less than $4 \mathrm{ft} / \mathrm{min}$ will be necessary in order to achieve high levels of $\mathrm{NO}_{\mathbf{x}}$ reduction ( $>80 \%$ ) and maintain ammonia slip at levels below $25 \mathrm{ppm}$.

From the results of the three test periods performed at $550^{\circ} \mathrm{F}$ (one each during PTC-IL6-428, PTC-BV-429, and PTC-BT-430), it appears that baghouse temperature has less of an effect on $\mathrm{NO}_{x}$ reduction than had been indicated by the results from PTC-IL6-426. Data from PTC-I16-426 indicated that $\mathrm{NO}_{\mathrm{x}}$ reduction decreased to $<30 \%$ when baghouse temperature was decreased to $550^{\circ} \mathrm{F}$. Data from the three subsequent runs identified indicated that $\mathrm{NO}_{\mathrm{x}}$ reduction was typically $70 \%$ to $80 \%$ when the baghouse temperature was reduced to $550^{\circ} \mathrm{F}$. Therefore, although the effect of temperature is not insignificant, it is not nearly as dramatic as indicated by the data from PTC-IL6-426. The low NO reduction observed at lower temperatures during PTC-IL6-426 was most likely caused by the formation of ammonium sulfate or bisulfate on the surface of flue gas pipes.

Overall, the $\mathrm{NO}_{\mathrm{x}}$ reduction for PTC-BV-429, PTC-BT-430, and PTC-RO-431 was quite good, however, the $\mathrm{NO}_{\mathrm{z}}$ reduction observed during PTC-BV-432 indicated decreasing performance with time. The decreasing $\mathrm{NO}_{\mathrm{z}}$ reduction may have been due to loss of catalyst or catalyst deactivation. Analysis of fabric samples is ongoing in an effort to determine the cause of decreased performance with time.

During each 100-hour run, $\mathrm{NO}_{x}$ reduction greater than theoretical were observed. This was more pronounced at lower ammonia $\mathrm{NO}_{z}$ molar ratios and air-to-cloth ratios, and may be due to an ammonia/ $\mathrm{NO}_{\mathrm{x}}$ reaction stoichiometry of less than 1:1. Further data evaluation and possibly bench-scale testing will be necessary before a firm conclusion can be drawn concerning the reaction mechanisms observed at low ammonia/ $\mathrm{NO}_{\mathbf{1}}$ molar ratios.

To this point, the particulate collection efficiency for the pulse-jet bags made from 22-ounce DE992 fabric has ranged from $96.1 \%$, during PTC.BV.432, to $>99.9 \%$, during PTC-BV-429, PTC.BT-430, and PTC-BV-432. From the data it can be seen that the collection efficiency was highest for the Black Thunder subbituminous coal and lowest for the Blacksville bituminous coal. Careful review of the data indicates that particulate collection efficiencies of $<99.9 \%$ were the result of differential pressure-control problems, flue gas leaks, and/or high levels ( $>25 \mathrm{ppm}$ ) of ammonia slip.

Multicyclone sampling at the inlet of the baghouse was completed in order to determine the aerodynamic particle size of the fly ash in the flue gas stream entering the baghouse for each test and each coal. Results show that for the Blacksville bituminous coal roughly $85 c_{c} c$ of the mass had a particle size greater than $10 \mu \mathrm{m}$, and roughly $78 \%$ of 
the mass had a particle size greater than $10 \mu \mathrm{m}$ for the Black Thunder subbituminous coal.

From the multicyclone and Coulter counter data, shown in Figures 22 through 26, the mass median diameter of the fly ash for each coal was determined. The baghouse hopper ash mass median diameter was $17 \mu \mathrm{m}$ for the Blacksville bituminous coal and $19 \mu \mathrm{m}$ for the Black Thunder subbituminous coal. For the fuel oil the mass median diameter was $35 \mu \mathrm{m}$. Keep in mind that the baghouse hopper ash collected during the oil. fired test was predominantly dolomite, as a result of precoating the bags.

Bulk ash samples collected from the hopper of the pulse-jet baghouse for each test were analyzed for carbon and major elements. The carbon content of the ash as determined by loss-on-ignition (LOI) and the major elements as determined by $\mathrm{x}$-ray fluorescence (XRF) analysis for each fuel are presented in Table 7. In order to reduce the carbon content of the ash when firing the Blacksville bituminous coal, the particle size was reduced to roughly $78 \% .200$ mesh. Carbon content of the ash decreased from an average of 14 wt \% during PTC-BV. 429 to an average of $5.38 \mathrm{wt} \%$ during PTC-BV-432, indicating increased combustion efficiency. The chemical composition of the ash samples analyzed are fairly typical for the coals fired. High silica, alumina, and iron was observed in the bituminous coal ash, and the alkali constituents are found in relatively low concentrations. The subbituminous ash samples exhibit higher alkali content and lower silica, alumina, and iron. The ash samples analyzed from the fuel oil test exhibited high LOI, $\mathrm{CaO}$, and $\mathrm{MgO}$ content due to the dolomite used to precoat the bags.

A concern with the use of catalyst-coated bags is the possibility of catalyst erosion resulting in decreased $\mathrm{NO}_{\mathrm{x}}$ reduction, increased ammonia slip, and an increase in the vanadium content of the fly ash. Although vanadium is not a Resource Conservation and Recovery Act (RCRA) element, some vanadium compounds are considered to be hazardous materials. It is important to measure vanadium concentration for new and used fabric samples and in the fly ash in order to determine if catalyst is lost from the fabric. Table 8 presents the vanadium concentration on unused and used samples for most fabric types. Although the used fabric samples are cleaned before being submitted, they still contain a certain amount of ash. This potential dilution effect may explain small vanadium concentration differences between the used and unused fabric samples. From the results, it appears there was essentially no loss of vanadium catalyst from the G143 and DE 484 bags. For PTC-IL6-419, PTC-IL6-127, and PTC-BV-432 extraneous ash can not be responsible for the large difference in vanadium concentration, and the results must be attributed to loss of catalyst from the bags. The upset conditions (moisture and acid dew point) of PTC-IL6- 427 appear to have caused approximately $25 \%$ loss of vanadium catalyst from the bags. The DE992 bags from PTC-II6-419 lost $19 \%$ of the vanadium catalyst, in this case the loss of catalyst may be due to the undercoat applied to the bags. One of the fabric samples removed from a bag that had failed in the baghouse at the UND Steam Plant showed a 30\% decrease in vanadium concentration, $4800 \mu \mathrm{g} / \mathrm{g}$ versus $6800 \mu \mathrm{g} / \mathrm{g}$. This wasn't surprising since this particular fabric sample was removed from the area of a hole that had developed in the bag due to the direct impingement of flue gas and particulate at high velocity. For the DE992 fabric from PTC-BV.432 the vanadium concentration decreased by about $15 \%$. Additional fabric samples, new and used, have been submitted for analysis in order to determine the statistical significance of the variation in vanadium concentrations observed. 


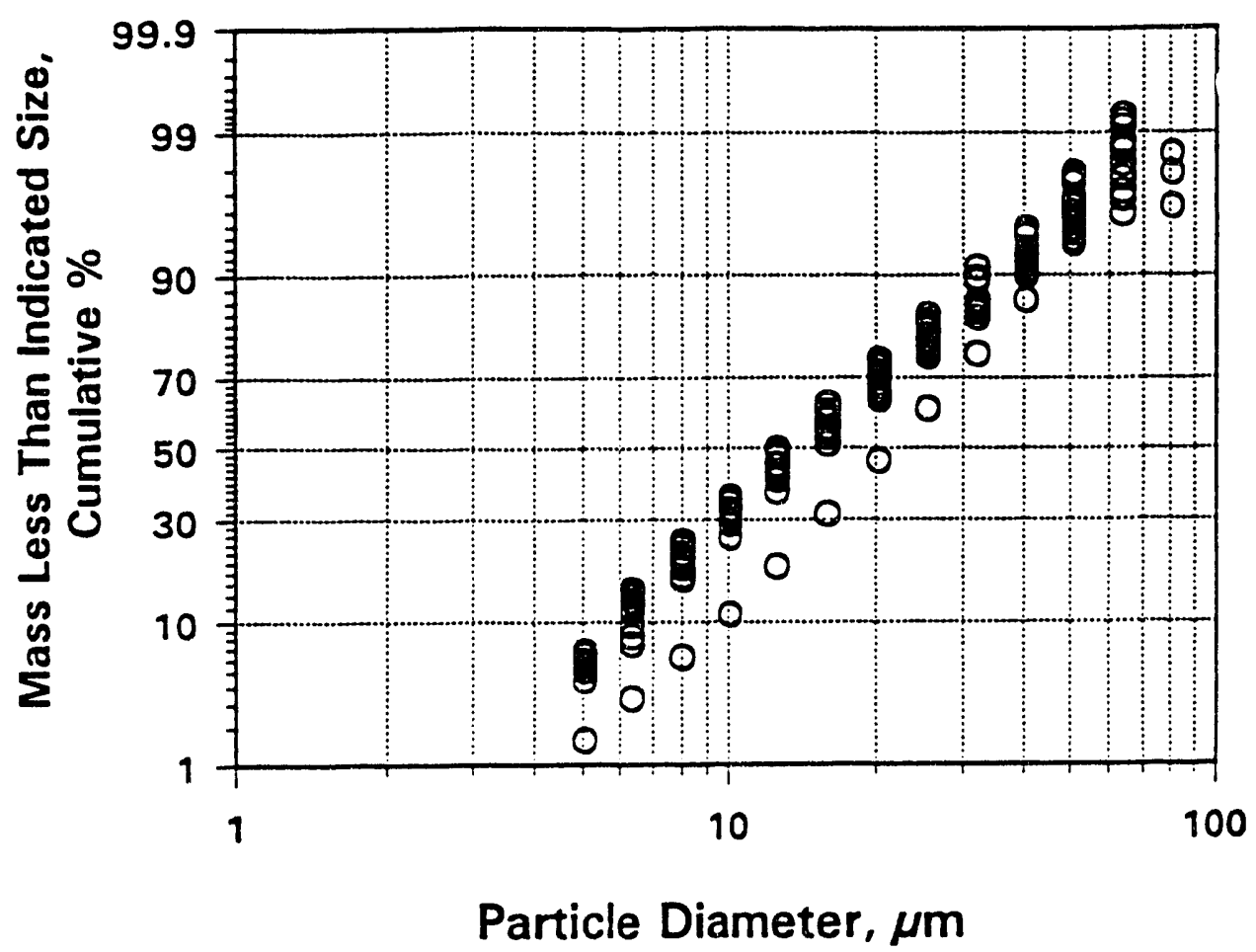

Figure 22. Coulter counter data for baghouse hopper ash when firing Blacksville bituminous coal.

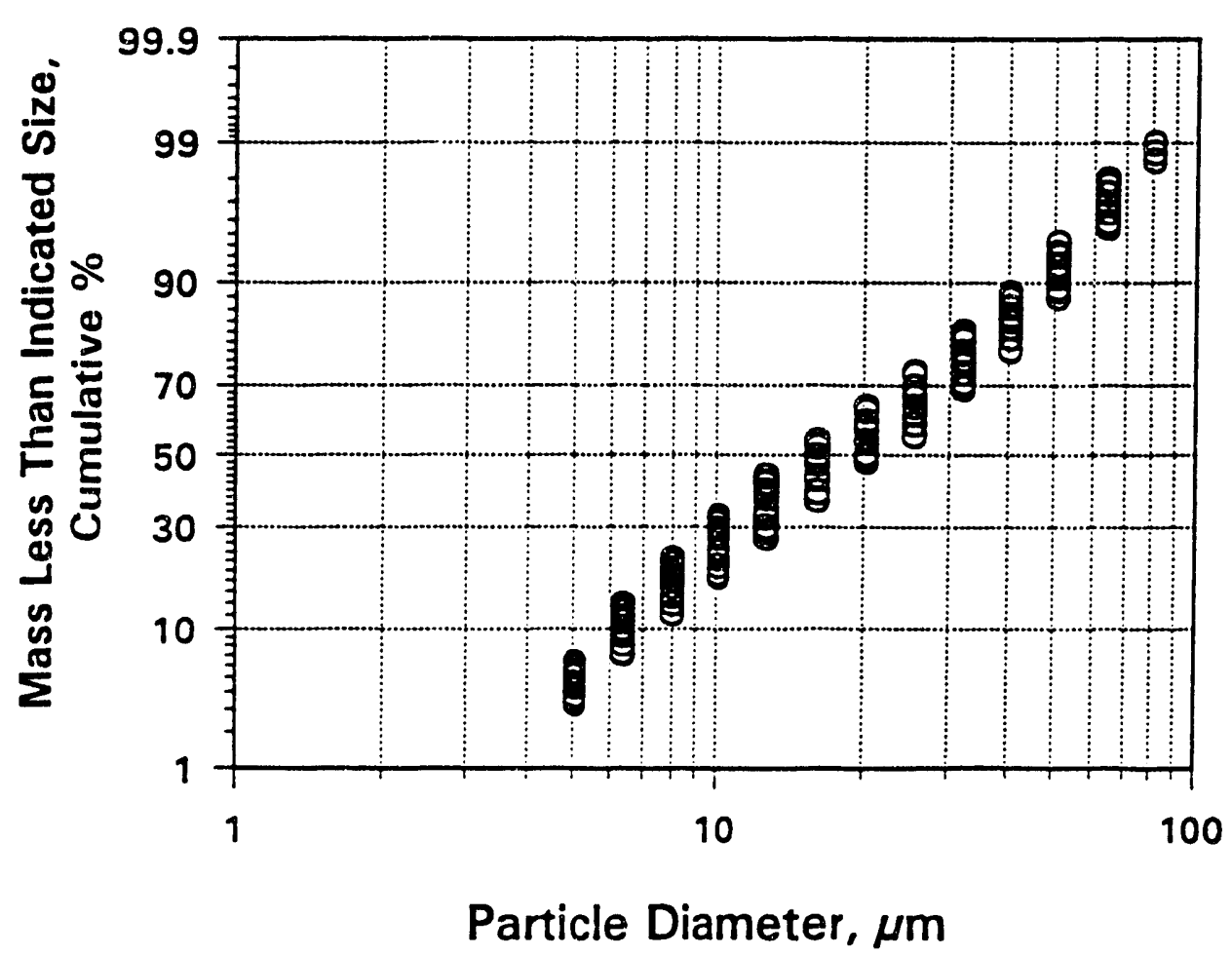

Figure 23. Coulter counter data for baghouse hopper ash when firing Black Thunder subbituminous coal. 


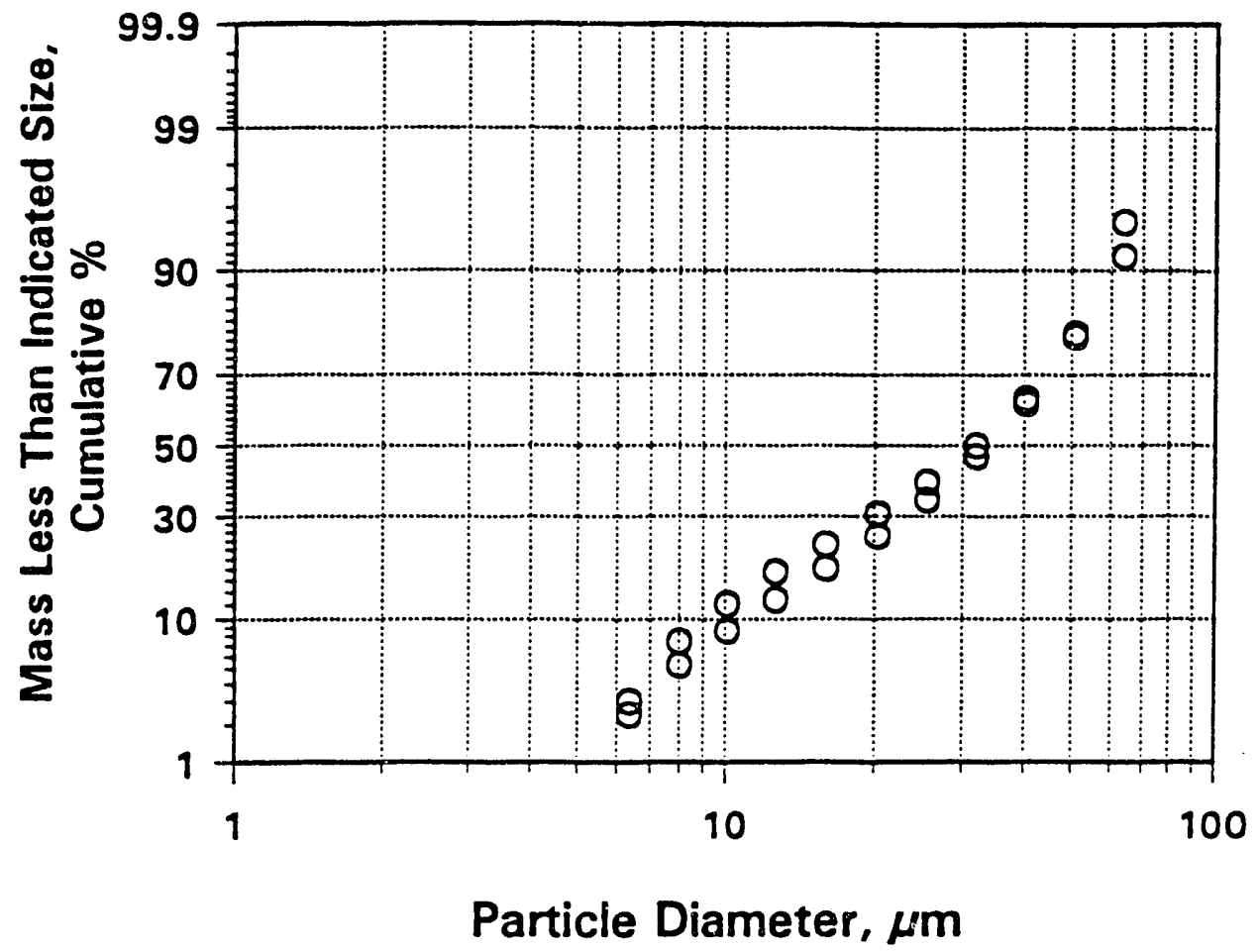

Figure 24. Coulter counter data for baghouse hopper ash when firing fuel oil.

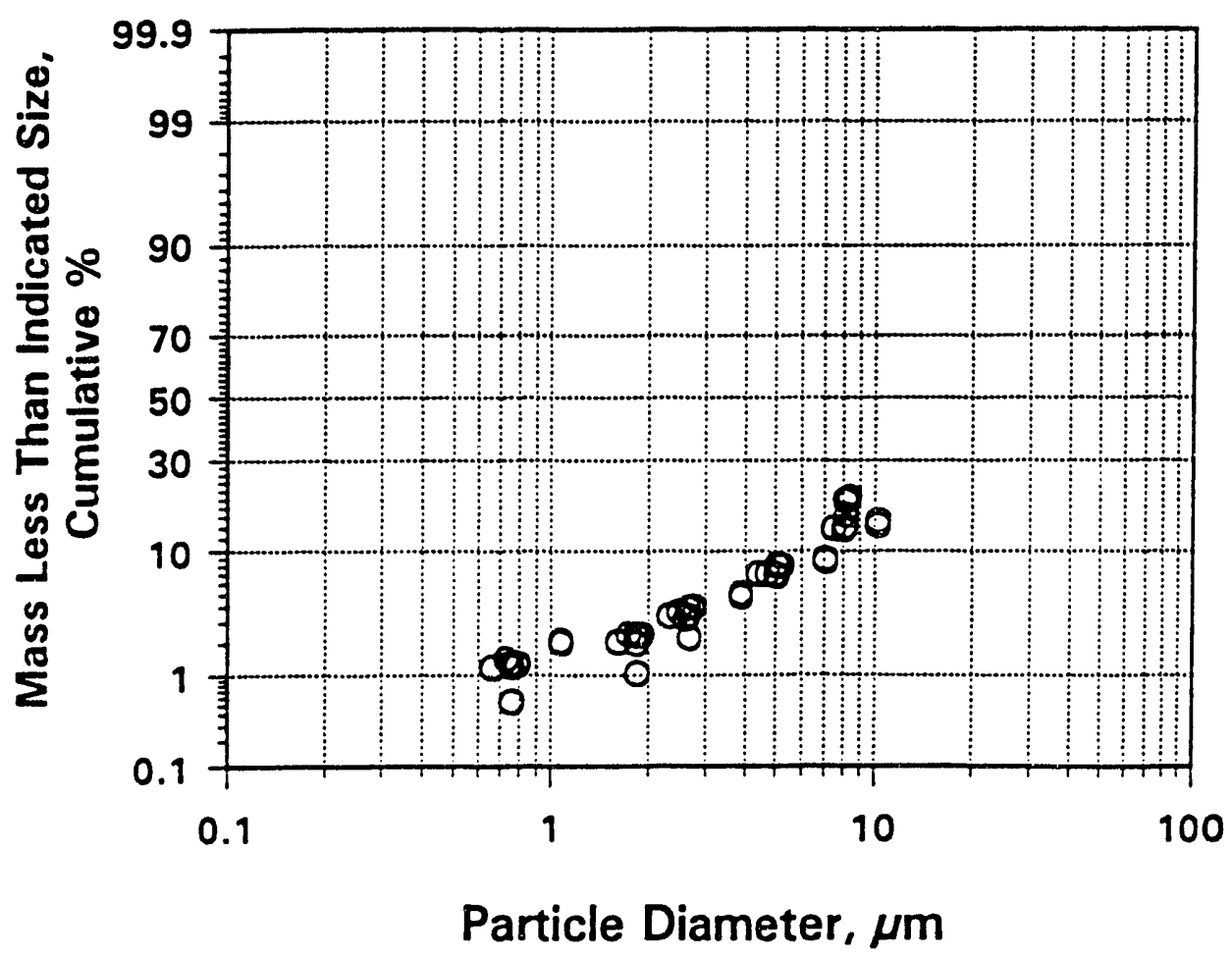

Figure 25. Multicyclone data for Blacksville bituminous coal fly ash. 


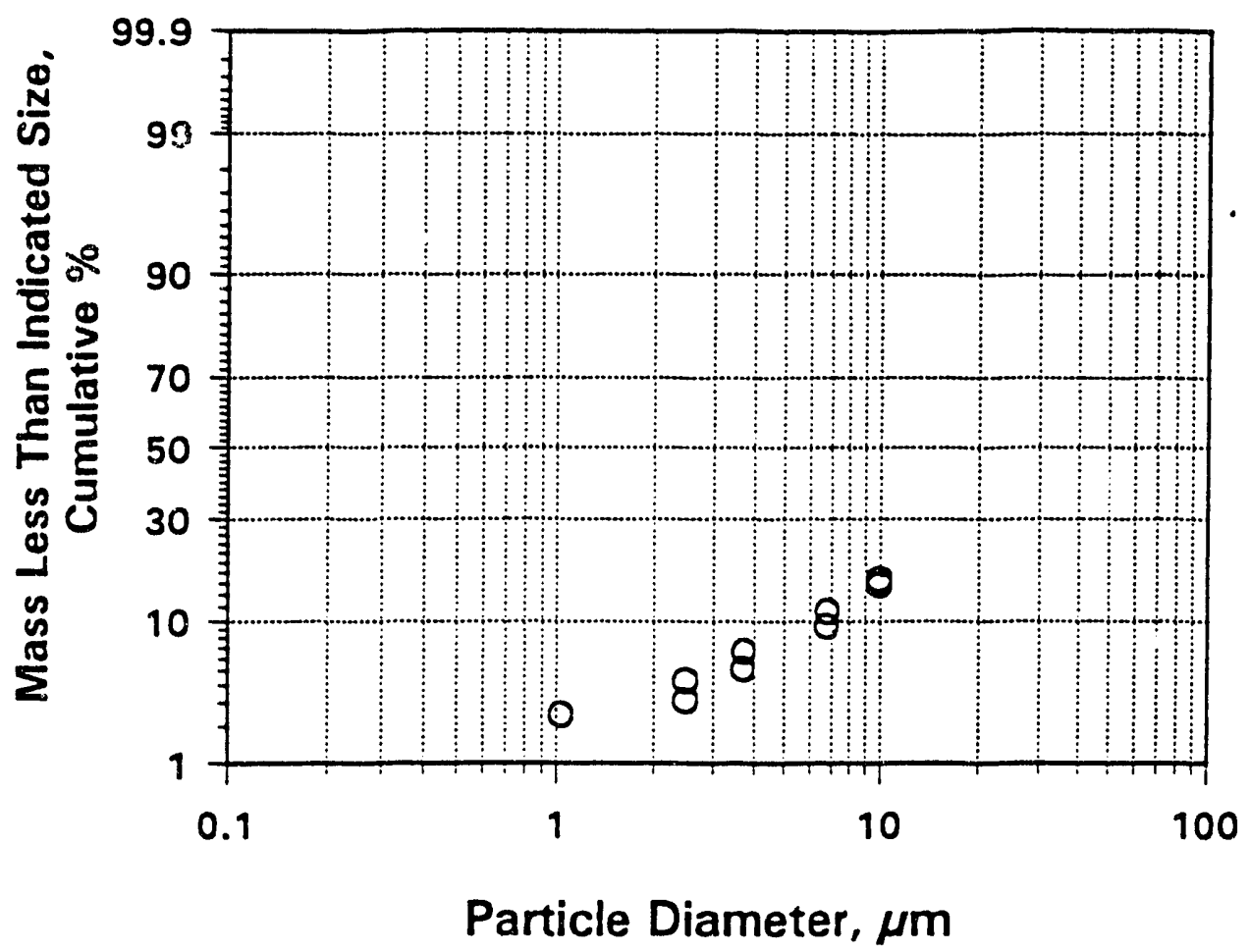

Figure 26. Multicyclone data for Black Thunder subbituminous coal fly ash.

\section{TABLE 7}

Baghouse Hopper Ash Analysis Results

\begin{tabular}{|c|c|c|c|c|c|c|c|c|c|}
\hline & \multicolumn{3}{|c|}{ Blacksville } & \multicolumn{3}{|c|}{ Black Thunder } & \multicolumn{3}{|c|}{ Fuel Oil } \\
\hline & Average & Marimum & Minimum & Average & Maximum & Minimam & Average & Marimum & Minimum \\
\hline $\mathrm{LOI}^{*}(\mathrm{wt} \%)$ & 11.73 & 22.02 & 4.86 & 0.70 & 1.76 & 0.33 & 39.16 & 41.48 & 36.84 \\
\hline \multicolumn{10}{|c|}{ Oxides (wt $\%$ of ash) } \\
\hline $\begin{array}{l}\mathrm{SiO}_{2} \\
\mathrm{Al}_{2} \mathrm{O}_{3} \\
\mathrm{Fe}_{2} \mathrm{O}_{3} \\
\mathrm{TiO}_{2} \\
\mathrm{P}_{2} \mathrm{O}_{3} \\
\mathrm{CaO} \\
\mathrm{MgO} \\
\mathrm{Na}_{2} \mathrm{O} \\
\mathrm{K}_{2} \mathrm{O} \\
\mathrm{SO}_{3}\end{array}$ & $\begin{array}{r}45.35 \\
21.61 \\
20.98 \\
0.91 \\
0.25 \\
5.74 \\
1.44 \\
0.72 \\
1.20 \\
1.82\end{array}$ & $\begin{array}{r}46.77 \\
23.03 \\
23.29 \\
1.30 \\
0.40 \\
6.62 \\
4.54 \\
0.93 \\
1.39 \\
2.51\end{array}$ & $\begin{array}{r}43.02 \\
19.51 \\
18.52 \\
0.68 \\
0.16 \\
4.84 \\
0.98 \\
0.58 \\
0.64 \\
1.36\end{array}$ & $\begin{array}{r}40.05 \\
16.76 \\
5.78 \\
1.15 \\
0.78 \\
24.49 \\
7.11 \\
1.51 \\
0.34 \\
2.09\end{array}$ & $\begin{array}{r}43.57 \\
17.27 \\
6.65 \\
1.22 \\
0.93 \\
25.99 \\
7.38 \\
1.75 \\
0.43 \\
2.61\end{array}$ & $\begin{array}{r}38.32 \\
16.24 \\
5.34 \\
1.00 \\
0.56 \\
22.48 \\
6.85 \\
1.05 \\
0.31 \\
1.41\end{array}$ & $\begin{array}{r}14.63 \\
1.02 \\
2.13 \\
0.39 \\
0.18 \\
47.60 \\
23.73 \\
0.39 \\
0.32 \\
9.62\end{array}$ & $\begin{array}{r}16.04 \\
1.23 \\
2.93 \\
0.42 \\
0.27 \\
50.79 \\
26.85 \\
0.42 \\
0.35 \\
13.85\end{array}$ & $\begin{array}{r}12.89 \\
0.62 \\
1.69 \\
0.35 \\
0.10 \\
43.97 \\
21.27 \\
0.36 \\
0.29 \\
4.65\end{array}$ \\
\hline
\end{tabular}

- LOI - Loss-on-ignition. 


\section{TABLE 8}

Vanadium Concentration on Catalytic Fabric Filter Bags

\begin{tabular}{cccc}
\hline Fabric Type & \multicolumn{2}{c}{ Vanadium Concentration, $\mu \mathrm{g} / \mathrm{g}$} & Run \\
& Unused Fabric & Used Fabric & \\
\hline G143 & 5300 & 5000 & PTC-IL6-417 \& PTC-NG-420 \\
DE484 & 7900 & 7533 & PTC-II-6-408/415 \& PTC-NG-421 \\
DE484 & 7900 & 5900 & PTC-IL6-427 \\
DE992-Undercoat & 6200 & 5033 & PTC-II.6-419 \\
DE992 & 6800 & $\ldots$. & \\
& & 4800 & PTC-BV-429, Steam Plant \\
& 6400 & PTC-BV-429, Steam Plant \\
& 6300 & PTC.BV-429, Steam Plant \\
& 7260 & PTC-BT-430 \\
& 7380 & PTC-RO-431 \\
& 6750 & PTC-BV-432, initial bags \\
& 5900 & PTC-BV-432, replacement bags \\
& 5700 & PTC-BV-432, replacement bags \\
\hline
\end{tabular}

- Unused fabric samples were heat-treated in an oven, and used fabric samples were heated in the pilot-scale baghouse and subsequently cut from bags upon completion of 100 -hour or 500-hour test periods.

Table 9 presents the vanadium content of the coal, fly ash from the inlet to the reverse-gas or pulse-jet baghouse, and ash from the baghouse hopper as determined by atomic absorption (AA) analysis. The differences in vanadium concentration in the baghouse ash for the different coals is directly related to the variation in coal vanadium and ash content, and has no relationship to the vanadium catalyst on the bags. When comparing the measured vanadium concentration in the fly ash to the theoretical concentration based on the concentration of the vanadium and ash in the coal, the vanadium concentration in the fly ash is higher in some cases. One explanation is that vanadium is known to be enriched in the fine particulate matter as a result of initial vaporization in the flame zone and subsequent condensation on fine ash particles (9). Although the concentration of the vanadium in the combustor bottom ash is not known, it is expected to be less than the concentration of the fly ash.

At this point, future pilot-scale test periods have not been scheduled. A decision concerning the completion of additional pilot-scale experimental activity will be made following the thorough evaluation of the data from PTC-BV.432, and the discussion of those results at a project review meeting in October.

\subsection{Subtask 3.4 - Fabric Durability Testing/Pulse-Jet System}

Pulse-jet bags were installed in the slipstream baghouse at the UND Steam Plant the first week in July 1992. These are the same pulse-jet bags used during the first 100-hour pulse-jet test (PTC-BV-429) completed July 2, 1992. Successful completion of the 100-hour pulse-jet test, and the results observed, established an excellent baseline from 


\section{TABLE 9}

Vanadium Concentration Analysis Results for Coal and Ash Samples

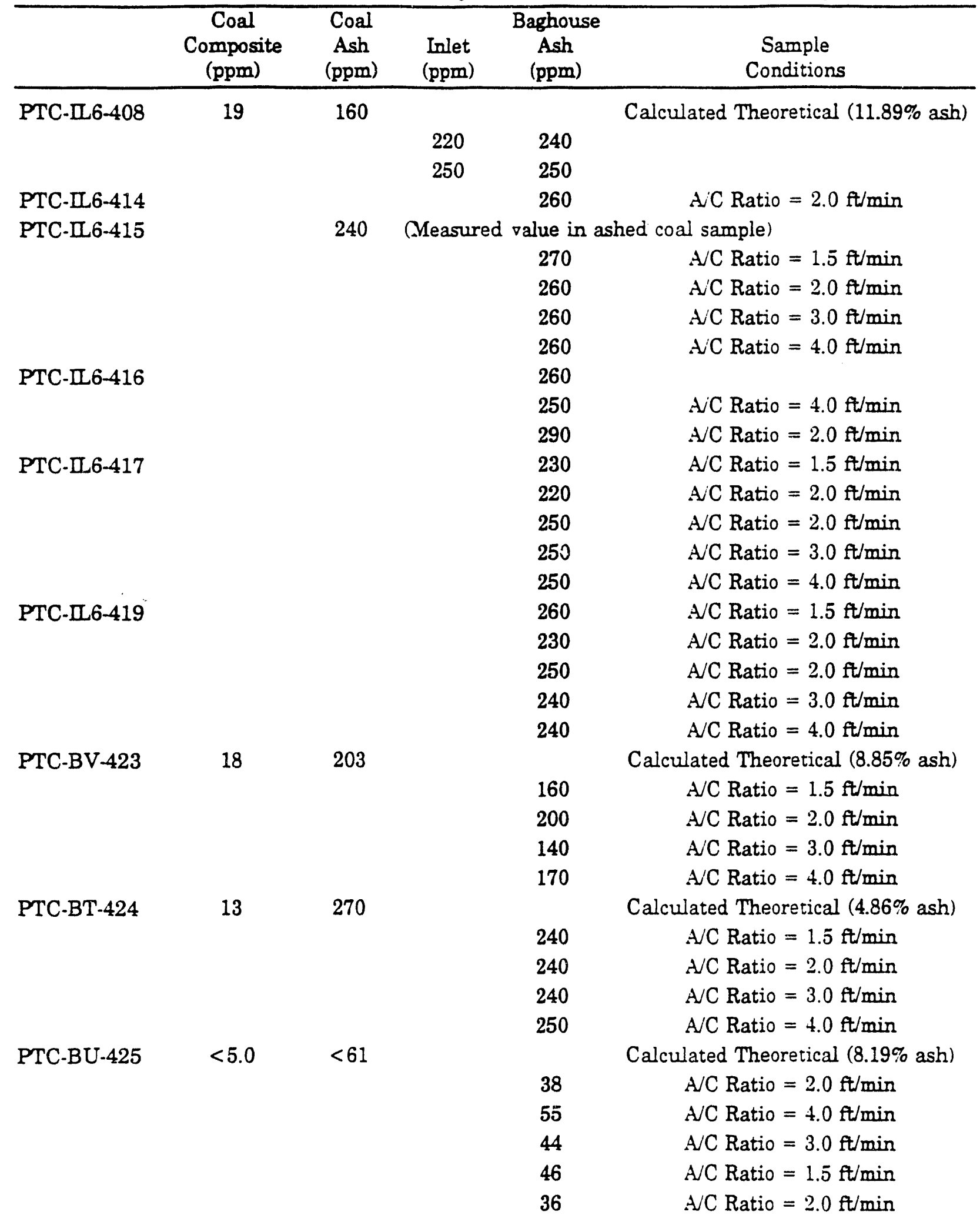


TABLE 9 (continued)

\begin{tabular}{|c|c|c|c|c|c|}
\hline & $\begin{array}{c}\text { Coal } \\
\text { Composite } \\
\text { (ppm) }\end{array}$ & $\begin{array}{c}\text { Coal } \\
\text { Ash } \\
\text { (ppm) }\end{array}$ & $\begin{array}{l}\text { Inlet } \\
\text { (ppm) }\end{array}$ & $\begin{array}{l}\text { Baghous } \\
\text { Ash } \\
\text { (ppm) }\end{array}$ & $\begin{array}{c}\text { Sample } \\
\text { Conditions }\end{array}$ \\
\hline \multirow[t]{8}{*}{ PTC-IL6-426 } & 30 & 270 & & & Calculated Theoretical (10.91\% ash) \\
\hline & & & & 240 & Baghouse Temp. $=700^{\circ} \mathrm{F}$ \\
\hline & & & & 250 & Baghouse Temp. $=650^{\circ} \mathrm{F}$ \\
\hline & & & & 240 & Baghouse Temp. $=600^{\circ} \mathrm{F}$ \\
\hline & & & & 240 & Baghouse Temp. $=550^{\circ} \mathrm{F}$ \\
\hline & & & & 230 & Baghouse Temp. $=500^{\circ} \mathrm{F}$ \\
\hline & & & & 230 & Baghouse Temp. $=750^{\circ} \mathrm{F}$ \\
\hline & & & & 220 & Baghouse Temp. $=650^{\circ} \mathrm{F}$ \\
\hline \multirow[t]{2}{*}{ PTC-IL6-427 } & & & & 230 & Upset Condition \#1 \\
\hline & & & & 220 & Upset Condition \#2 \\
\hline \multirow[t]{5}{*}{ PTC-II6-428 } & & & & 220 & AC Ratio $=2.0 \mathrm{ft} / \mathrm{min}$ \\
\hline & & & & 240 & AC Ratio $=4.0 \mathrm{ft} / \mathrm{min}$ \\
\hline & & & & 230 & $A C$ Ratio $=1.5 \mathrm{ft} / \mathrm{min}$ \\
\hline & & & & 240 & AC Ratio $=3.0 \mathrm{ft} / \mathrm{min}$ \\
\hline & & & & 260 & AC Ratio $=2.0 \mathrm{ft} / \mathrm{min}$ \\
\hline \multirow[t]{5}{*}{ PTC-BV-429 } & & & & 160 & AC Ratio $=2.0 \mathrm{ft} / \mathrm{min}$ \\
\hline & & & & 180 & AC Ratio $=4.0 \mathrm{ft} / \mathrm{min}$ \\
\hline & & & & 190 & AC Ratio $=3.0 \mathrm{ft} / \mathrm{min}$ \\
\hline & & & & 180 & AC Ratio $=1.5 \mathrm{ft} / \mathrm{min}$ \\
\hline & & & & 210 & $\mathrm{AC}$ Ratio $=2.0 \mathrm{ft} / \mathrm{min}$ \\
\hline \multirow[t]{5}{*}{ PTC-BT- 430} & & & & 260 & AC Ratio $=: 0 \mathrm{ft} / \mathrm{min}$ \\
\hline & & & & 260 & A/C Ratio $=3.0 \mathrm{ft} / \mathrm{min}$ \\
\hline & & & & 260 & A $/$ Ratio $=2.0 \mathrm{ft} / \mathrm{min}$ \\
\hline & & & & 260 & $A C$ Ratio $=6.0 \mathrm{ft} / \mathrm{min}$ \\
\hline & & & & 260 & AC Ratio $=2.0 \mathrm{ft} / \mathrm{min}$ \\
\hline \multirow[t]{4}{*}{ PTC-BV-432 } & 13 & 163 & & & Calculated Theoretical (7.98\% ash) \\
\hline & & & & 180 & Week $\ddagger 1$ \\
\hline & & & & 180 & Week $\neq 2$ \\
\hline & & & & 190 & Week $\div 3$ \\
\hline
\end{tabular}

which to evaluate fabric performance/durability in the Steam Plant pulse-jet baghouse. The nine bags originally installed in the baghouse were precoated with dolomite to establish an initial dust layer to protect the fabric from burning carbon particles that may enter the baghouse from the stoker-fired boiler. The three spare bags will be used as replacement bags after roughly 1000,2000 , and 4000 hours of operation.

With the exception of a two-day period (July 21 through July 22) where the baghouse was shut down due to scheduled boiler maintenance, the slipstream baghouse was operated from July 16 through August 21, 1992. As of August 21, the baghouse had accumulated 840 hours of operation. As is shown in Figures 27 and 28 , the baghouse operated at an average flue gas temperature of $550^{\circ}$ to $600^{\circ} \mathrm{F}$ and at an air-to-cloth ratio 


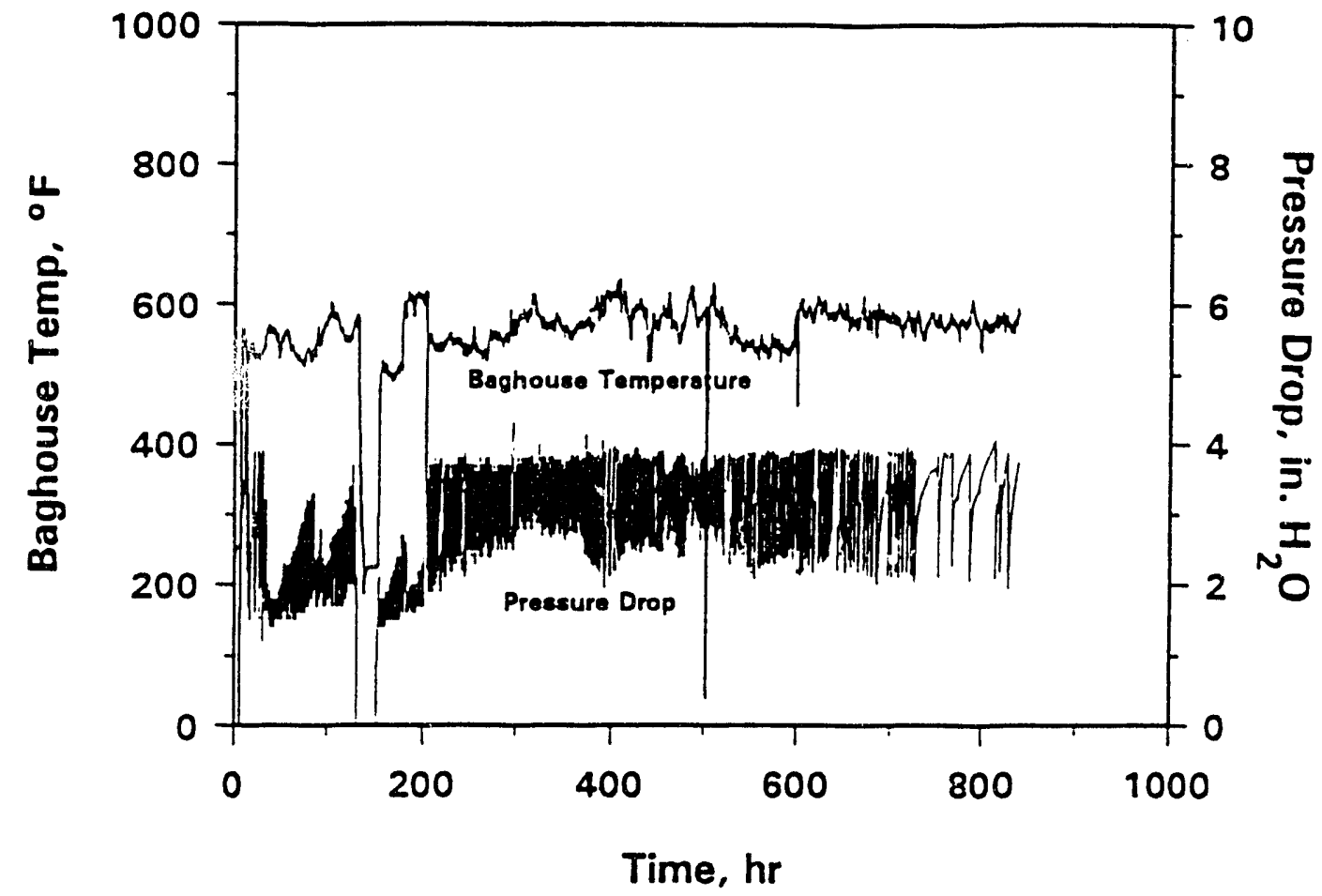

Figure 27. Steam Plant baghouse temperature and pressure drop as a function of time.

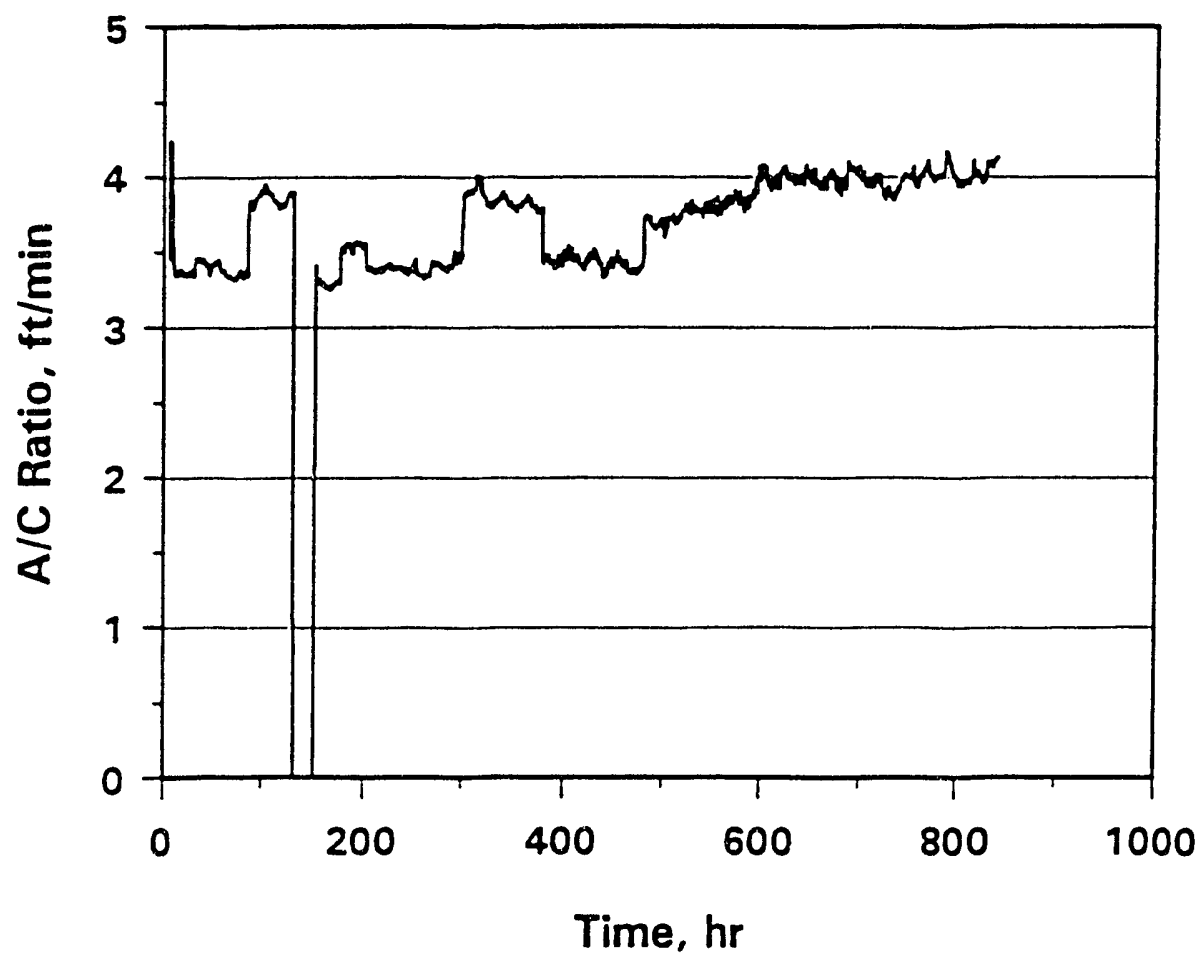

Figure 28. Steam Plant baghouse air-to-cloth ratio as a function of time. 
of 3.5 to $4 \mathrm{ft} / \mathrm{min}$. During the first week of operation, the baghouse was cleaned as a function of time, every two hours, and pressure drop was controlled between 1.5 and 4.0 inches W.C. Following the first week, the baghouse cleaning cycle was initiated as a function of pressure drop. Once steady state was obtained, the pressure drop was maintained between 2 and 4 inches $W$.C.

The particulate collection efficiency was measured during the first week of operation and during the third week in August. Results from the first sampling activities indicated that the flue gas from the stoker-fired boiler had a fly ash mass loading of $1.5 \mathrm{gr} / \mathrm{scf}$ and moisture, oxygen, and carbon dioxide levels of $8 \%, 6 \%, 12 \%$ by volume, respectively. Additional ash was injected upstream of the baghouse resulting in an inlet loading of $2.6 \mathrm{gr} / \mathrm{scf}$. Figure 29 shows the particle-size distribution of the fly ash at the inlet of the baghouse, as determined using a multicyclone. The major elemental composition of the fly ash (XRFA) is shown in Table 10.

Two outlet dust loading measurements were made with the ash injection system operating. The first outlet measurement indicated a mass loading of $0.0001 \mathrm{gr} / \mathrm{scf}$ and the second $0.0005 \mathrm{gr} / \mathrm{scf}$. These measurements result in mass collection efficiencies of $99.99 \%$ and $99.98 \%$, respectively. The higher outlet mass loading measured during the second sampling period represents the effect of one cleaning cycle, whereas, the first outlet measurement represents emissions between cleaning cycles. Using the APS sampling system, the respirable mass emissions were found to be low, as shown in Figure 30, averaging $2 \times 10^{-3} \mathrm{mg} / \mathrm{m}^{3}$.

Particulate collection efficiency was again measured on August 20, 1992. Results of the particulate-sampling showed particulate collection efficiency ranging from $85 \%$ to $90 \%$, indicating bag failure. Operation of the baghouse was discontinued on August 21 to permit inspection of the baghouse and to determine the cause for the high levels of particulate emissions measured. Inspection of the baghouse revealec that one of the bags had failed and a second showed significant wear. The bag failure was caused by the failure of a blanik flange in the top of the baghouse. Failure of the blank flange resulted in direct impaction of the fly ash on the surface of one bag at high flue gas velocities, resulting in a 2. to 3-inch-diameter hole in both sides of the first bag and significant wear on the surface of the second bag. Based on the pressure-drop data, failure of the blank flange occurred in mid-August. Replacement bags will be installed in the baghouse before system operation is resumed, which is expected in mid-October.

The exact number of operating hours that will be accumulated on the baghouse at the UND Steam. Plant will depend on UND Steam Plant operating plans in 1992 and 1993 and the availability of project funds to support the activity. It is unlikely that operation of the baghouse for 12,000 hours will be possible. It appears that the boiler from which the slipstream baghouse gets its ilue gas will resume operation in October. By late December, the EERC Project Manager will have determined the availability of funding to continue operation of the slipstream baghouse, and at what point additional funding will be required to avoid termination of slipstream baghouse operation. Other impacts will include boiler shutdowns to tie-in a new stack and baghouse in late 1992 or early 1993. This shutdown will probably be 2 to 4 weeks in duration. 


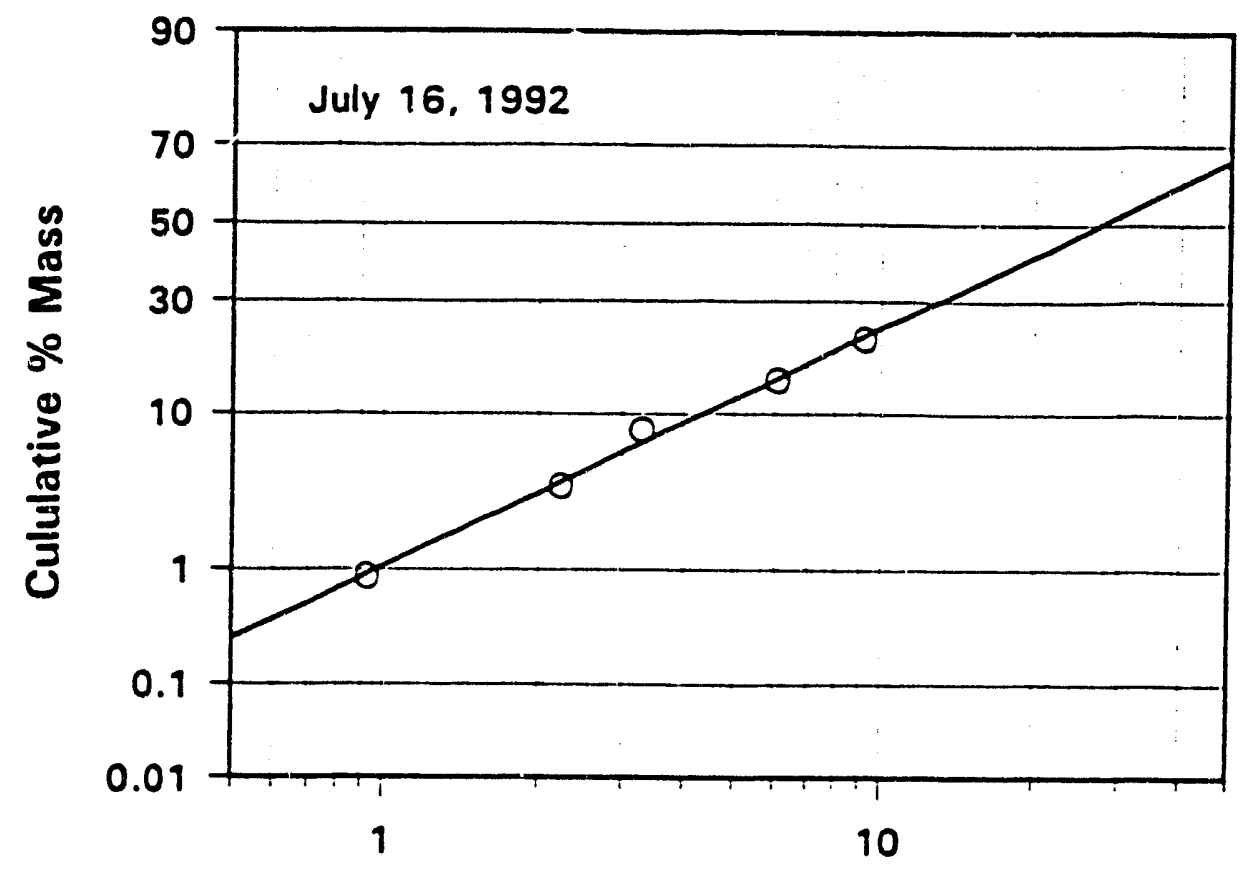

Aerodynamic Diameter, $\mu \mathrm{m}$

Figure 29. Multicyclone data from the Steam Plant baghouse.

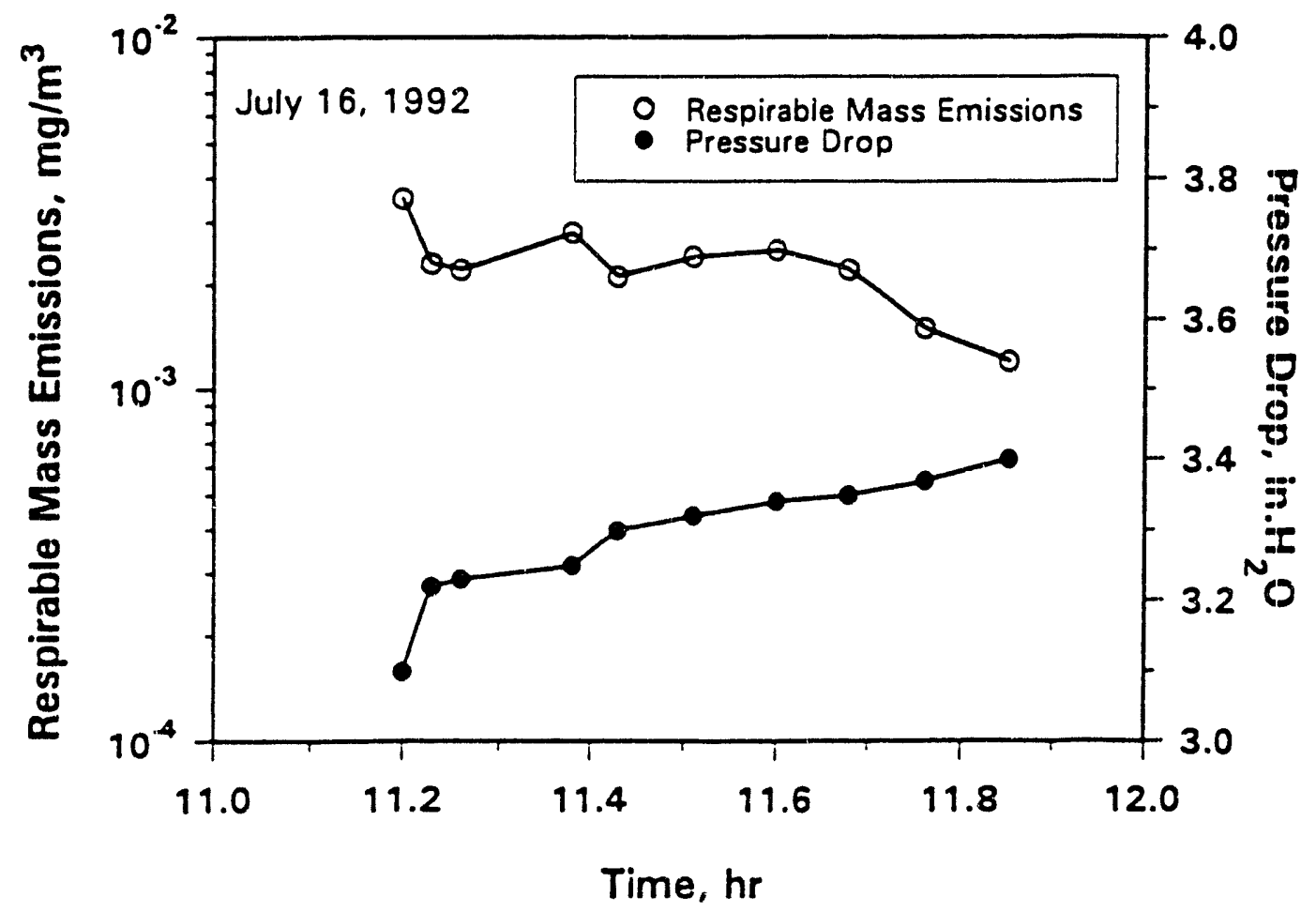

Figure 30. Respirable mass emissions as a function of time for the Steam Plant baghouse. 
TABLE 10

XRF Ash Analysis of Steam Plant Baghouse Hopper Ash

\begin{tabular}{cc}
\hline Oxide & $\mathrm{Wt} \%$ \\
\hline $\mathrm{SiO}_{2}$ & 7.30 \\
$\mathrm{Al}_{2} \mathrm{O}_{3}$ & 1.74 \\
$\mathrm{Fe}_{2} \mathrm{O}_{3}$ & 0.45 \\
$\mathrm{TiO}_{2}$ & 0.04 \\
$\mathrm{P}_{2} \mathrm{O}_{3}$ & 0.91 \\
$\mathrm{CaO}$ & 44.01 \\
$\mathrm{MgO}$ & 0.72 \\
$\mathrm{Na}_{2} \mathrm{O}$ & 0.28 \\
$\mathrm{~K}_{2} \mathrm{O}$ & 0.20 \\
$\mathrm{SO}_{3}$ & 44.35 \\
\hline
\end{tabular}

\subsection{KEY PERSONNEL STAFFING REPORT}

Table 11 presents planned versus actual workhours for key EERC and UE\&C personnel involved in the Catalytic Fabric Filtration project through September 1992.

\section{TABLE 11}

Planned Versus Actual Workhours

for Key Personnel Through September 1992

\begin{tabular}{lccc}
\hline Key Personnel & $\begin{array}{c}\text { Planned } \\
\text { Hours }\end{array}$ & Actual Hours & $\begin{array}{c}\text { \% of Total Available Workhours } \\
\text { Used }\end{array}$ \\
\hline Greg Weber & 1594 & 1266 & 79 \\
Dennis L. Laudal & 2408 & 1002 & 42 \\
Chris Robie & 29 & 16 & 55 \\
\hline
\end{tabular}

\section{REFERENCES}

1. Pirsh, E.A. U.S. Patent 4220 633, Sep. 2, 1980, assigned to Babcock and Wilcox Co.

2. Pirsh, E.A. U.S. Patent 409 386, Jan. 5, 1982, assigned to Babcock and Wilcox Co.

3. Doyle, J.B. et al. U.S. Patent 4793 981, Dec. 27, 1988, assigned to Babcock and Wilcox Co. 
4. Weber, G.F. "SO $\mathrm{NO}_{\mathbf{x}}$ Control, Low-Rank Coal Research under the UND/DOE Cooperative Agreement," quarterly technical progress report; DOELFE $60181-1531$, EERC publication, Jan. 1984, Section 6.

5. Kalinowski, M.R.; Nishioka, G.M. "Method for Applying Porous Metal Oxide Coatings to Relatively Nonporous Fibrous Substrates," United States Patent No. 4 732 879, Mar. 22, 1988.

6. Weber, G.F.; Laudal, D.L. " $\mathrm{SO}_{\mathrm{z}} / \mathrm{NO}_{\mathrm{x}}$ Control - Catalytic Fabric Filtration for Simultaneous $\mathrm{NO}_{x}$ and Particulate Control," final technical report for the period Apr. 1, 1988, through Jun. 30, 1989; DE.FC21-86MC10637, EERC publication, Aug. 1989.

7. Weber, G.F.; Miller, S.J.; Laudal, D.L. "Flue Gas Cleanup," final technical report for the period Jul. 1, 1989, through Jun. 30, 1990; DE-FC21-86MC10637, EERC publication, Oct. 1990.

8. Weber, G.F.; Ness, S.R.; Laudal, D.L.; Dunham, G. "Catalytic Fabric Filtration for Simultaneous $\mathrm{NO}_{\mathrm{x}}$ and Particulate Control," quarterly technical report for the period Apr. 1, 1992, through Jun. 30, 1992; DE-AC22-90PC90361, EERC publication, Aug. 1992.

9. Markowski, G.W.; Filby, R. "Trace Element Concentration as a Function of Particle Size in Fly Ash from a Pulverized Coal Utility Boiler," Environmental Science and Technology 1985, 19 (9). 

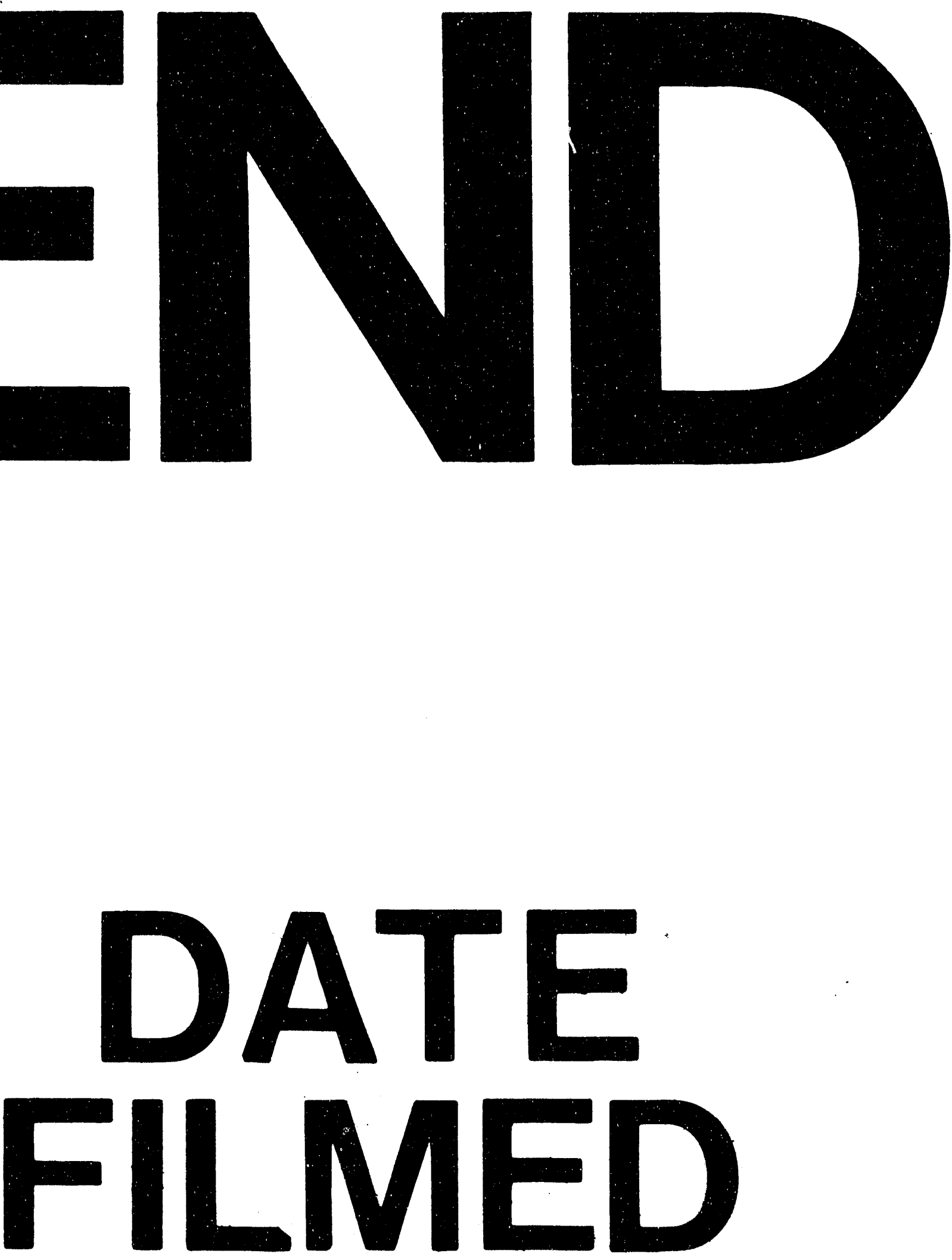

1

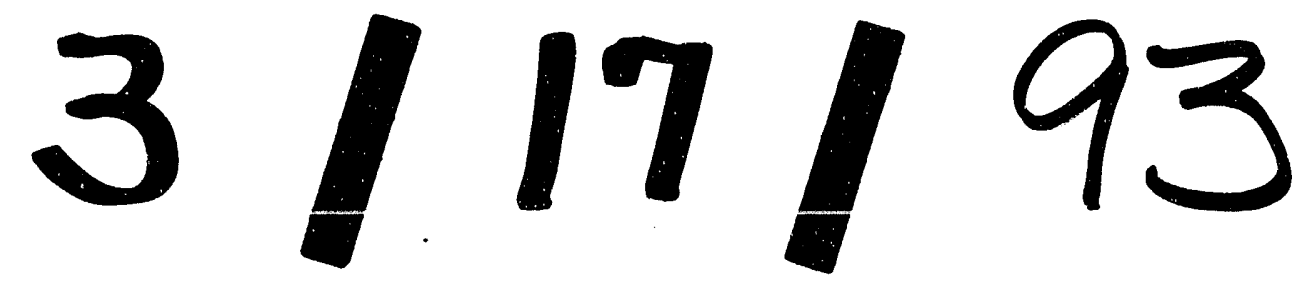


